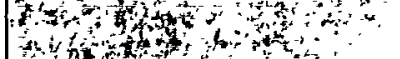

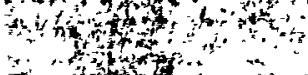

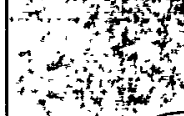

$\rightarrow+2$

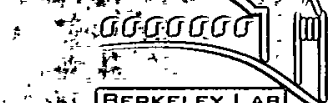

- $\therefore$ Bis BERKELEY LAB

$x^{2}-a^{2}+y^{2}$

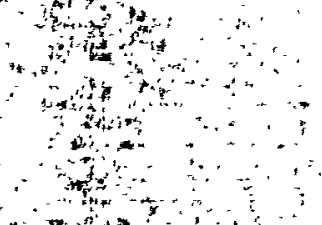

$\therefore n+4$

- in

6

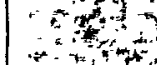

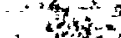

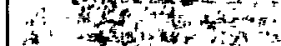

A.

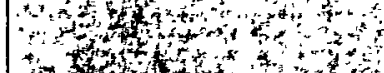

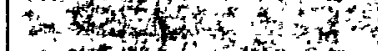
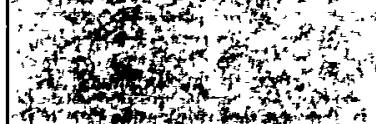

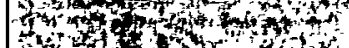

\section{(3)}

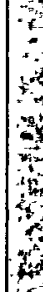

ERNEST

BERKELEY NATIDNAL LABQRATIRY

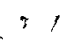

RECEIVE

MAR 29699

OSTI

\section{Wind Generation in the \\ Future Competitive \\ California Power Market}

Osman Sezgen, Chris Marnay, and Sarah Bretz

Environmental Energy

Technologies Division

March 1998

March 1998 


\section{DISCLAIMER}

This document was prepared as an account of work sponsored by the United States Government. While this document is believed to contain correct information, neither the United States Government nor any agency thereof, nor The Regents of the University of California, nor any of their employees, makes any warranty, express or implied, or assumes any legal responsibility for the accuracy, completeness, or usefulness of any information, apparatus, product, or process disclosed, or represents that its use would not infringe privately owned rights. Reference herein to any specific commercial product, process, or service by its trade name, trademark, manufacturer, or otherwise, does not necessarily constitute or imply its endorsement, recommendation, or favoring by the United States Government or any agency thereof, or The Regents of the University of California. The views and opinions of authors expressed herein do not necessarily state or reflect those of the United States Government or any agency thereof, or The Regents of the University of California.

This report has been reproduced directly from the best available copy.

Available to DOE and DOE Contractors

from the Office of Scientific and Technical Information

P.O. Box 62, Oak Ridge, TN 37831

Prices available from (615) 576-8401

Available to the public from the National Technical Information Service

U.S. Department of Commerce

5285 Port Royal Road, Springfield, VA 22161

Ernest Orlando Lawrence Berkeley National Laboratory

is an equal opportunity employer. 


\section{DISCLAIMER}

Portions of this document may be illegible in electronic image products. Images are produced from the best available original document. 


\title{
Wind Generation in the Future Competitive California Power Market
}

\author{
Osman Sezgen, Chris Marnay, and Sarah Bretz \\ (AOSezgen@lbl.gov,C_Marnay@lbl.gov, and SEBretz@lbl.gov) \\ Environmental Energy Technologies Division \\ Ernest Orlando Lawrence Berkeley National Laboratory \\ University of California \\ Berkeley, California 94720
}

March 1998

The work described in this study was funded by the Assistant Secretary of Energy Efficiency and Renewable Energy, Office of Utility Technologies, Office of Energy Management Division of the U.S. Department of Energy under Contract No. DE-AC03-76SF00098. 


\section{Contents}

Acknowledgments $\ldots \ldots \ldots \ldots \ldots \ldots \ldots \ldots \ldots \ldots \ldots \ldots \ldots \ldots \ldots \ldots \ldots \ldots$ iii

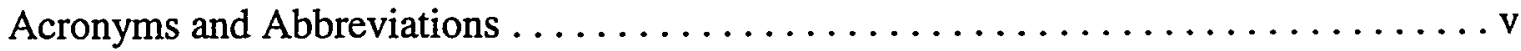

Abstract $\ldots \ldots \ldots \ldots \ldots \ldots \ldots \ldots \ldots \ldots \ldots \ldots \ldots \ldots \ldots \ldots \ldots \ldots \ldots \ldots \ldots$

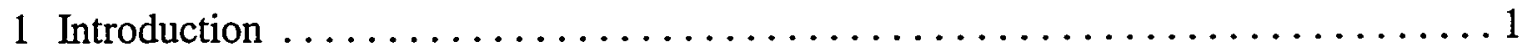

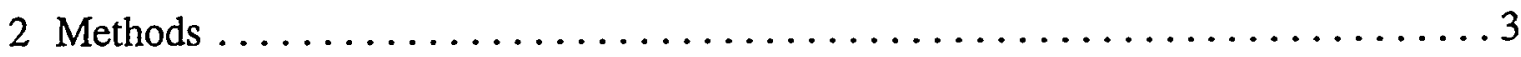

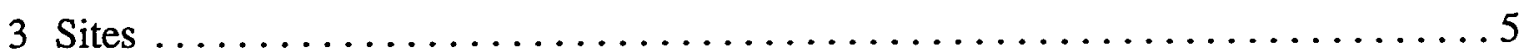

4 Choice of Technology and Cost Function ..................... 19

5 Capacity and Profitability of Wind Resources $\ldots \ldots \ldots \ldots \ldots \ldots \ldots \ldots \ldots$

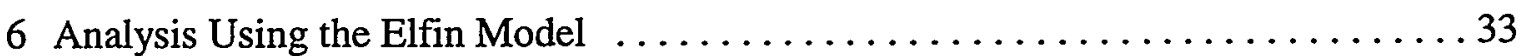

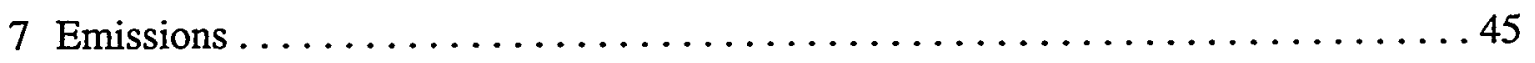

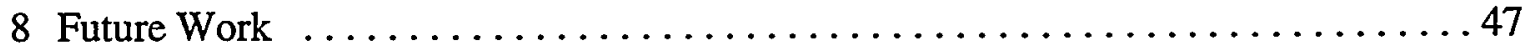

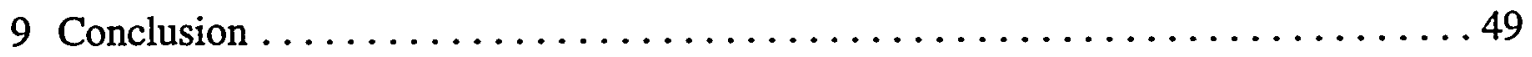

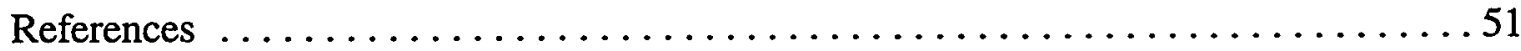

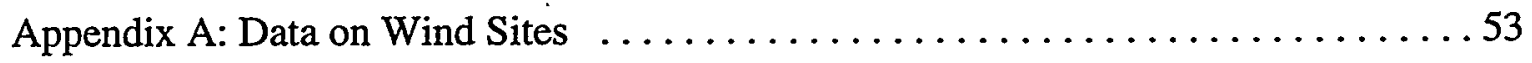

Appendix B: Sample Wind Input to the Elfin Model $\ldots \ldots \ldots \ldots \ldots \ldots$ 


\section{Acknowledgments}

The authors would like to thank Jack Cadogan of the U.S. Department of Energy, Pat McAuliffe, Angela Tanghetti, and Joel B. Klein of the California Energy Commission, Brian Parsons, Michael Milligan, and Kevin Porter of the National Renewable Energy Lab, Dan Kirshner and Francis Chapman of the Environmental Defense Fund, and Joseph Eto and Jon Koomey of the Berkeley Lab for their help at various stages of this work. The work described in this study was funded by the Assistant Secretary of Energy Efficiency and Renewable Energy, Office of Utility Technologies, Office of Energy Management Division of the U.S. Department of Energy under Contract No. DE-AC03-76SF00098. 


\section{Acronyms and Abbreviations}

$\begin{array}{ll}\text { CAD } & \text { Computer-aided design } \\ \text { CEC } & \text { California Energy Commission } \\ \text { CPUC } & \text { California Public Utilities Commission } \\ \text { DEM } & \text { Digital Elevation Map } \\ \text { DOI } & \text { U.S. Department of the Interior } \\ \text { EDF } & \text { Environmental Defense Fund } \\ \text { ESRI } & \text { Environmental Systems Research Institute } \\ \text { FEMA } & \text { Federal Emergency Management Agency } \\ \text { GIS } & \text { Geographic Information System } \\ \text { ITRE } & \text { Iterative Test of Resource Effectiveness } \\ \text { LBNL } & \text { Lawrence Berkeley National Laboratory (Berkeley Lab) } \\ \text { NREL } & \text { National Renewable Energy Laboratory } \\ \text { USGS } & \text { U.S. Geological Survey }\end{array}$




\section{Abstract}

The goal of this work is to develop improved methods for assessing the viability of wind generation in competitive electricity markets. The viability of a limited number of possible wind sites is assessed using a geographic information system (GIS) to determine the cost of development, and Elfin, an electric utility production costing and capacity expansion model, to estimate the possible revenues and profits of wind farms at the sites. This approach improves on a simple profitability calculation by using a site-specific development cost calculation and by taking the effect of time varying market prices on revenues into account.

The first component of the work is to develop data characterizing wind resources suitable for use in production costing and capacity expansion models, such as Elfin, that are capable of simulating competitive electricity markets. An improved representation of California wind resources is built, using information collected by the California Energy Commission (CEC) in previous site evaluations, and by using a GIS approach to estimating development costs at 36 specific sites. These sites, which have been identified as favorable for wind development, are placed on Digital Elevation Maps (DEMs) and development costs are calculated based on distances to roads and transmission lines. GIS is also used to develop the potential capacity at each site by making use of the physical characteristics of the terrain, such as ridge lengths. In the second part of the effort, using a previously developed algorithm for simulating competitive entry to the California electricity market, the Elfin model is used to gauge the viability of wind farms at the 36 sites.

The results of this exercise are forecasts of profitable development levels at each site and the effects of these developments on the electricity system as a whole. Under best guess assumptions, including prohibition of new nuclear and coal capacity, moderate increase in gas prices and some decline in renewable capital costs, about $7.35 \mathrm{GW}$ of the $10 \mathrm{GW}$ potential capacity at the 36 specific sites is profitably developed and 62 TWh of electricity produced per annum by the year 2030. Most of the development happens during the earlier years of the forecast. Sensitivity of these results to future gas price scenarios is also presented. This study also demonstrates that an analysis based on a simple levelized profitability calculation approach does not sufficiently capture the implications of time varying prices in a competitive market. 


\section{Introduction}

The goal of this work is to develop improved methods for assessing the viability of wind generation in competitive electricity markets. In this phase, the profitability of a limited number of sites is estimated, and the likelihood of development determined. The approach improves on current capacity expansion approaches in a number of ways.

1. Rather than depending on a single generic resource to represent wind potential, a number of actual sites are evaluated individually.

2. The cost of development at each site is estimated using both generic technology cost information and site specific information.

3. Wind farm revenues are estimated based on patterns of generation derived from actual wind observations and estimates of time-varying market prices. In addition to attempting to improve on standard practice for capacity expansion modeling, this paper also demonstrates the benefits of such an approach when compared to simple levelized cost analyses.

The first step in the process is characterizing wind resources in a manner suitable for inclusion in production costing and capacity expansion models of electric power systems, such as the Elfin model, that are capable of simulating competitive markets. This characterization is typically in the form of a data set for model input that embodies the three key features that determine the viability of wind development: (1) estimates of the total resource; (2) estimates of the costs of developing the resource, and (3) an estimate of hourly potential generation. The information in (3) is of the utmost importance because it allows estimation of a potential revenue stream from sales into a competitive electricity market. Specifically, in this demonstration, an improved representation of the California wind resource is developed in the form of an Elfin data base, using information collected in previous site evaluations conducted by the California Energy Commission (CEC) and by using a geographic information system (GIS) approach to estimating development costs at specific sites. The Elfin model then uses these data to gauge the viability of wind farms at 36 specific sites. The results of this exercise are forecasts of profitable levels of development at each site, and forecasts of the effects of these developments on the electricity system as a whole, on fuel consumption, emissions, pool prices, etc. 



\section{Methods}

\section{Elfin}

The Elfin ${ }^{1}$ model is a production costing and capacity expansion simulation program that has been widely used in California and elsewhere. Elfin uses a load duration curve dispatch simulation method, and picks an expansion program for the industry using the Iterative Test of Resource Effectiveness (ITRE) algorithm (EDF 1997). ITRE provides particularly attractive characteristics for work of this kind. ITRE is a simple search algorithm in which the most profitable new investments are made first and other investments chosen to the point that no further profitable new plant construction can be made. While this approach does not guarantee an optimal result and can lead to lengthy searches for the multiple possible equilibrium combinations of new investments, ITRE is capable of considering a large number of potential resource additions. In contrast to more common search methods, such as dynamic programming, choosing between many specific investment options does not lead to an insurmountable curse of dimensionality. Despite the vast number of combinations of investments possible at 36 wind sites over a 25 -year period, ITRE successfully delivers results in reasonable computing times, typically a few days, on a Sun workstation. ${ }^{2}$ The ability to assess the viability of numerous alternatives is particularly important when multiple renewable generation options are to be evaluated because these tend to have much more variable characteristics than thermal technologies. In other words, while from an engineering standpoint, a modular combustion turbine can operate similarly anywhere within the state, wind sites will exhibit quite different output patterns. The Berkeley Lab has previously set up an Elfin model of the future California Pool. This database is a simple aggregation of the existing thermal generating resources owned by the incumbent investor-owned utilities together with in-state non-utility generators. The Berkeley Lab and EDF have also developed and implemented an algorithm for estimating the profitable level of entry by new capacity into the California market and for finding the combination of new investment that is the most profitable for investors (Marnay et al. 1997a).

To date, modeling of the California electricity market by the Berkeley Lab has focused on broad magnitudes of entry by new capacity, including renewable generators. Wind has consistently emerged as one of the renewable resources closest to commercial viability, but, prior to this work, no effort has been made to identify the exact extent and characteristics of wind resources within or near to the state; rather, wind has been represented within the Elfin model in the form of a simple generic generating resource with unlimited supply at a stated fixed development cost. Since wind generation appears to be the renewable resource most

1 Elfin is a proprietary product of the Environmental Defense Fund.

2 Sun UltraSPARC $2(200 \mathrm{MHz})$ under Solaris 2.5 .1 
likely to penetrate the California fuel mix, a more rigorous modeling capability for the overall supply potential of this resource is necessary both to gauge the potential of wind, and to forecast operation of the California market with a significant wind contribution.

\section{Geographic Information System}

In this study, a more detailed inventory of the wind potential has been incorporated into the existing Elfin data base, providing a dramatic improvement over the current generic representation. This inventory has been developed in two stages. First, CEC studies conducted in the 1970s and early 1980s of favorable California wind sites were reviewed. These studies not only identify sites but also provide chronological wind data and other useful base information. Second, using GIS $^{3}$, these sites have been placed on topographic maps and their proximity to transmission lines and roads calculated. This information yields a more realistic estimate of development costs at the sites, and introduces a previously non-existent spatial element into the Elfin analysis. In simple production costing, possible generation options are represented as generic options that are chosen by the model based either traditionally on cost minimization, or, more recently, on profitability. The options contain no geographic information because any one unit of the generic resource is identical to any other. However, by developing multiple generic options based on actual surveyed sites, whose cost characteristics have been calculated using GIS, not only is the overall representation of the resource more accurate, but GIS also brings a spatial component into the analysis.

This inventory of wind sites has been entered into the Elfin model in the form of multiple generic resources, each representing the wind potential at one of the sites. Elfin capacity expansion runs then choose the viable sites and build wind farms accordingly. The key point to note is that the best wind sites in terms of wind class may not be the ones chosen first, for two reasons: first, the wind pattern may not be coincident with times of high electricity market prices; and second, the sites with good wind speeds may have other characteristics, such as poor transmission access that would make them costly relative to poorer but bettersituated resources. In other words, Elfin is presented with a long-run supply curve of wind resources and it finds the level of development justified by the market price, but, because the information on the production and price sides is available, typically every three hours, this supply curve is complex and could not be readily drawn. 


\section{Sites}

\section{Previous Site Studies}

The California Energy Commission (CEC) funded an extensive series of wind resource assessment studies in the late 1970s and early 1980s. ${ }^{4}$ These studies were conducted by various organizations ranging from research organizations, like SRI International, to meteorological consulting firms, to one-time wind generator manufacturers, like Boeing. As a result, the content and quality of the reports vary but the main emphasis in all of them is wind characterization at locations favorable to wind farm development.

The CEC studies do not cover the sites along the coastal mountains of Central California because, at the time, the Bureau of Reclamation of the U.S. Department of the Interior (DOI) was conducting its own wind energy study (DOI 1983).

A summary report by the CEC (Waco et al. 1983) evaluates all the consultant reports including the DOI study for the Central California coastal ranges and identifies Solano and Alameda Counties, the major east-west passes of Southern California (Tehachapi and San Gorgonio passes), and In-Ko-Pah Gorge in eastern San Diego County as the most promising sites with annual average wind speeds greater than $7 \mathrm{~m} / \mathrm{s}(16 \mathrm{mph})$. Certain ridges below

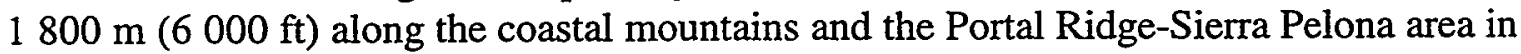
northern Los Angeles County, and several other locations with annual average wind speeds in the range of 6 to $7 \mathrm{~m} / \mathrm{s}(13-16 \mathrm{mph})$ are also identified.

Based on the CEC studies, 36 sites suitable for development are identified (Table 1). As mentioned above, some of these sites have high average annual wind speeds (greater than 7 $\mathrm{m} / \mathrm{s}$ ). Marginal areas with average annual wind speeds in the range of 6 to $7 \mathrm{~m} / \mathrm{s}$ are also included in our study set in case the diurnal and seasonal patterns of wind speed at these sites makes them more desirable than their average wind speeds indicate. More detail on the sites appears in Appendix A. California (Ruff et al. 1983), Alameda and Solano Counties (Davis et al. 1980), Southern California Desert (Berry et al. 1981), Southern California (Zambrano et al. 1981), Palm Springs-Whitewater region (Zambrano et al. 1980), and San Diego County (Richmond et al. 1980). Furthermore, the reports that were produced as a result of CEC efforts in this field are not limited to the list presented here. 
Table 1. Wind Sites and Numbers Used in This Report Identifying These Sites

\begin{tabular}{|c|c|c|}
\hline Identifier & Site & Site information $^{5}$ \\
\hline 1 & Bear River Ridge & (good) \\
\hline 2 & Solano Hills & (good) \\
\hline 3 & Solano Hills & (marginal) \\
\hline 4 & Altamont Pass & (good) \\
\hline 5 & Altamont Pass & (marginal) \\
\hline 6 & San Gorgonio & Northern Foothills (good) \\
\hline 7 & San Gorgonio & Whitewater (good) \\
\hline 8 & San Gorgonio & Cabazon (marginal) \\
\hline 9 & Tehachapi Pass & Cameron and Oak Ridges (good) \\
\hline 10 & Tehachapi Pass & Pejuela Peak (good) \\
\hline 11 & Tehachapi Pass & Downslope (marginal) \\
\hline 12 & Tehachapi Mountains & La Liebre Ridge (marginal) \\
\hline 13 & Barstow & (good) \\
\hline 14 & Barstow & (marginal) \\
\hline 15 & Mountain Pass & (good) \\
\hline 16 & Mountain Pass & Clark Mountains (good) \\
\hline 17 & Gorman & Sandberg (marginal) \\
\hline 18 & Sierra Pelona & (marginal) \\
\hline 19 & Soledad Canyon & (marginal) \\
\hline 20 & Portal Ridge & (marginal) \\
\hline 21 & Fairmont Reservoir & (good) \\
\hline 22 & Santa Catalina & \\
\hline 23 & Cajon Pass & (marginal) \\
\hline 24 & Cajon Mountain & (good) \\
\hline 25 & Strawberry Peak & (marginal) \\
\hline 26 & Mt. Laguna & (good) \\
\hline 27 & Julian & Vulcan Mountain (good) \\
\hline 28 & In-Ko-Pah & Boulder Park (good) \\
\hline 29 & In-Ko-Pah & Sugarloaf Mountain (marginal) \\
\hline 30 & Table Mountain & (good) \\
\hline 31 & Jacumba Mountains & (good) \\
\hline 32 & Walker Ridge & (good) \\
\hline 33 & Berryessa Peak & (marginal) \\
\hline 34 & Potrero Hills & (good) \\
\hline 35 & Pacheco Pass & (marginal) \\
\hline 36 & Cottonwood Pass & (marginal) \\
\hline
\end{tabular}

$5 \quad$ good: wind speed at $10 \mathrm{~m}$ is greater than $6.7 \mathrm{~m} / \mathrm{s}$ marginal: wind speed at $10 \mathrm{~m}$ is less than $6.7 \mathrm{~m} / \mathrm{s}$ 


\section{Topographical Maps}

At the outset, the intention was to develop a list of potential wind sites using data on wind power, roads, transmission data, population data, blackout areas such as federal land, and any other relevant GIS data sets available. Because a number of obstacles obtaining the necessary GIS data sets were encountered, the analysis was limited to the sites identified by the CEC, as described in Previous Studies.

Figure 1 shows the 36 sites studied here. The actual site is at the hub of the windmill icon. The figure also shows areas of the state that were identified as possible blackout areas, that is, areas in which wind development may be precluded by special land use restrictions. Not marked are urban areas, which, similarly, are unlikely to prove hospitable to wind farms. This GIS information is not used in this analysis but is shown here to demonstrate how the GIS analysis could be expanded.

We obtained road data by converting an Environmental Systems Research Institute (ESRD) Arcview U.S. road data set (ESRI 1993) into an ArcInfo map, and selecting California roads. Difficulties were experienced obtaining an accurate transmission line map. One of the maps we obtained proved to be unusable because of problems with georeferencing of the original (computer-aided design) $\mathrm{CAD}$ file and attaching attribute data. Transmission lines obtained from the Federal Emergency Management Agency (FEMA 1988) were ultimately used. The lines were created by connecting known points in the distribution system of $115-500 \mathrm{kV}$ lines. There is no attribute data associated with the lines. This transmission line map will be replaced by detailed data under development by the CEC. Figure 2 shows the potential wind sites against the roads and transmission lines. GIS was used to estimate proximity of CEC wind sites to roads and transmission lines. These distances serve as the basis for an estimated cost function of wind development.

Data on wind power were obtained from the National Renewable Energy Laboratory (Elliott et al 1986). A map of the wind power classes developed from their data is shown in Figure 3. Wind power classes are used to describe the energy contained in wind, averaged over area and time (Table 2). Areas designated Class 4 or greater are deemed suitable for advanced wind turbine technology under development today. The wind power classes were assigned based on the available windy land and wind electric potential per grid cell (Elliott and Schwartz 1997). Thus, they present a general idea of the wind power in a grid cell. 
Figure 1. Potential Wind Sites

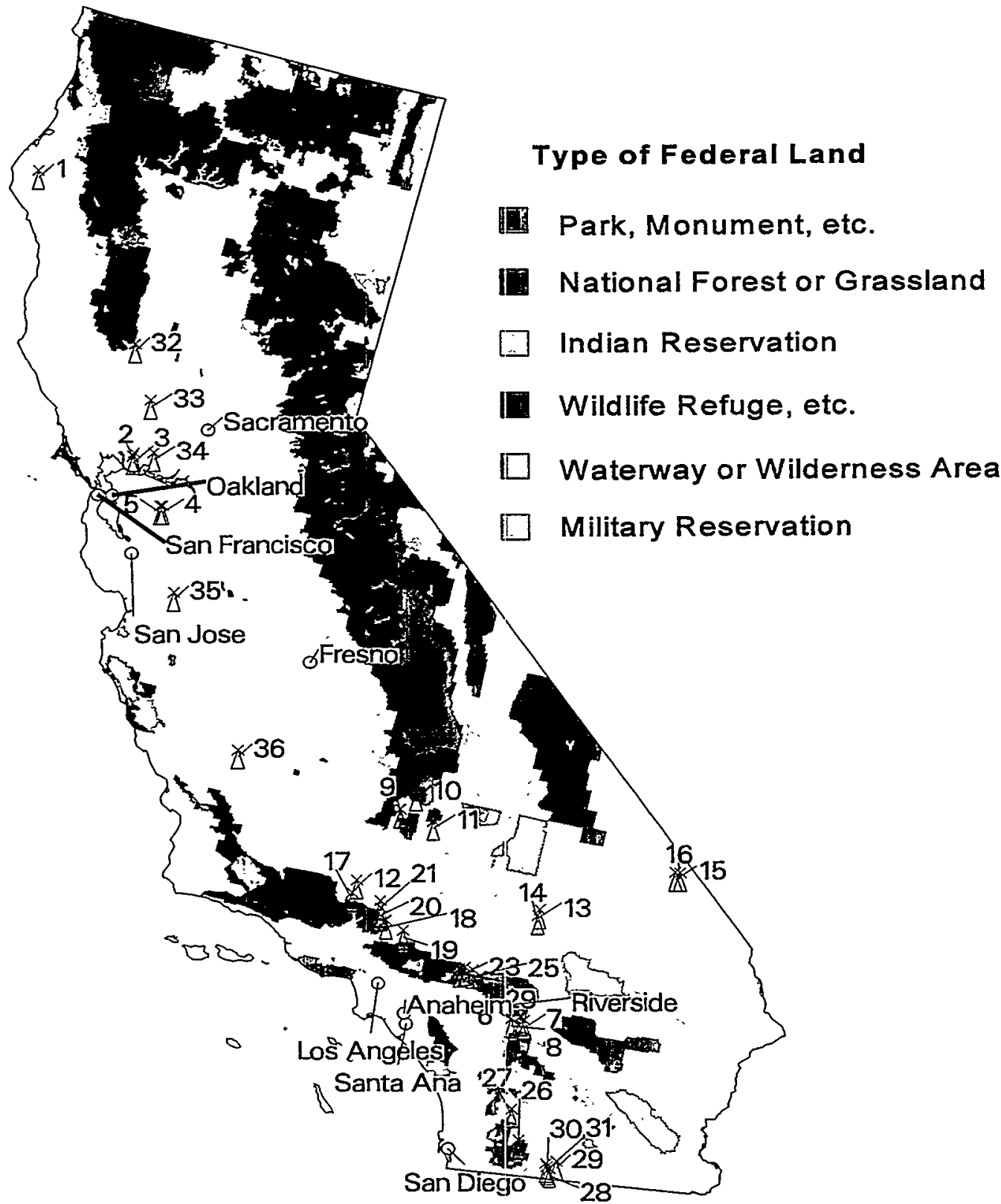

Data from USGS and ESRI 
Figure 2. Potential Wind Sites, Transmission Lines and Roads

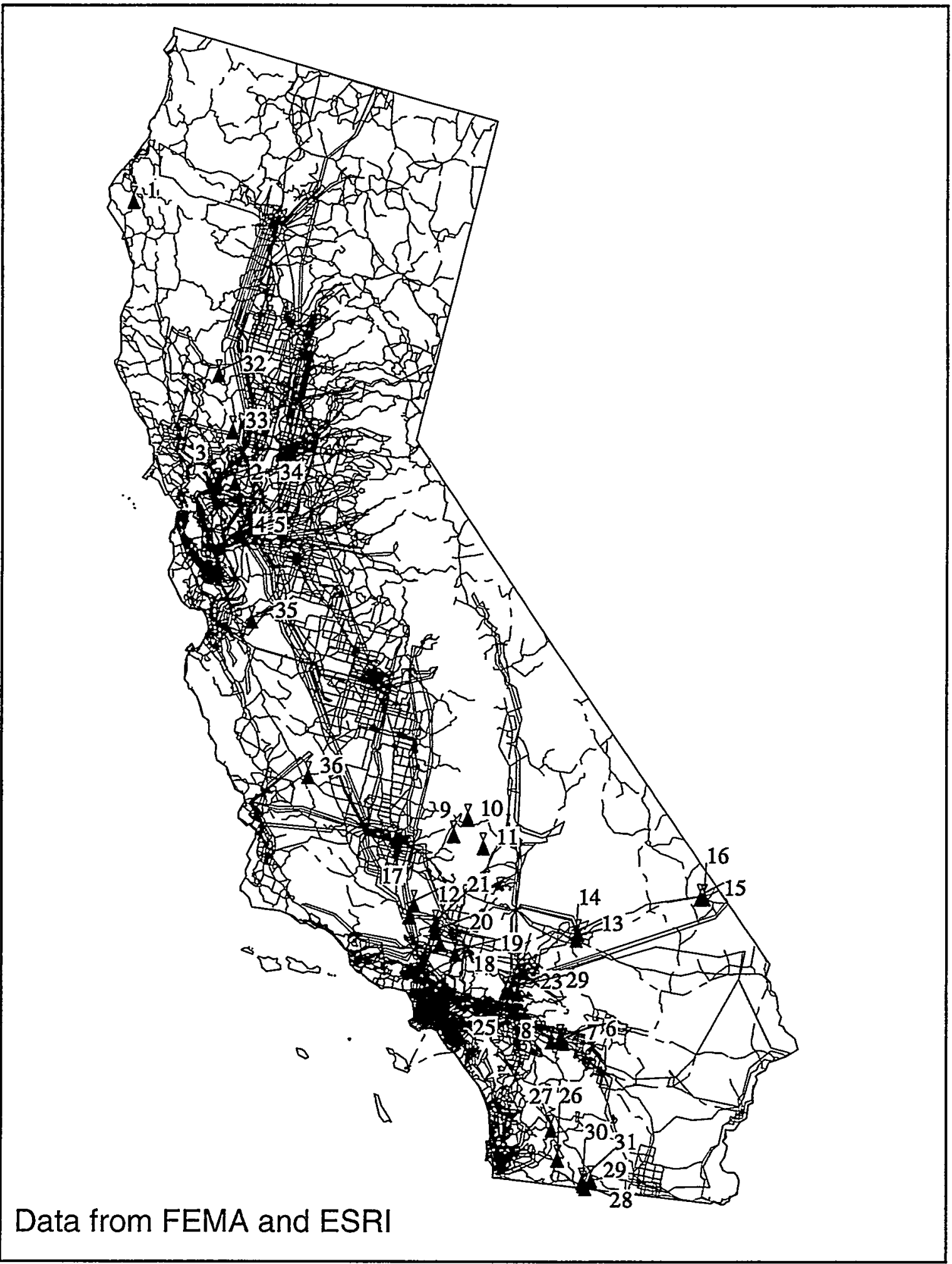


Figure 3. Wind Power Classes and Transmission Lines

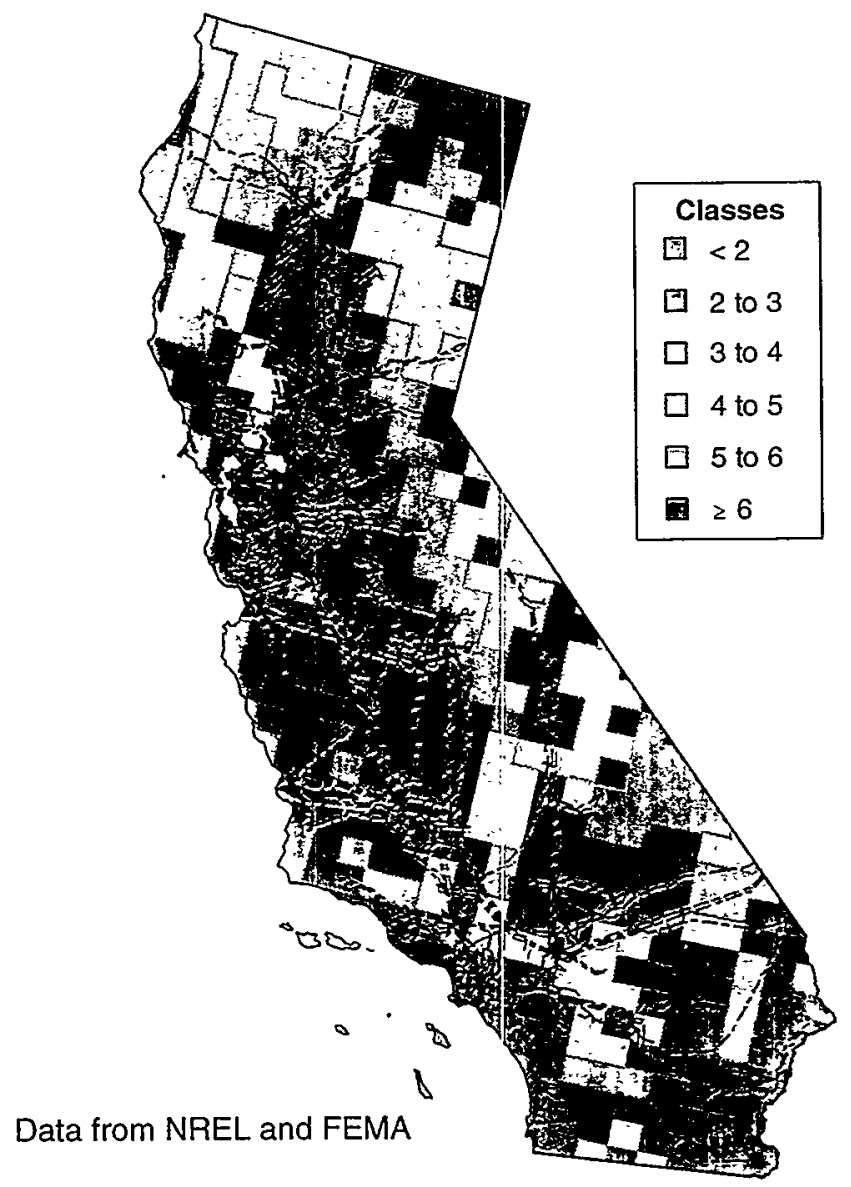

Table 2. Wind Power Classes at $50 \mathrm{~m}(164 \mathrm{ft})$

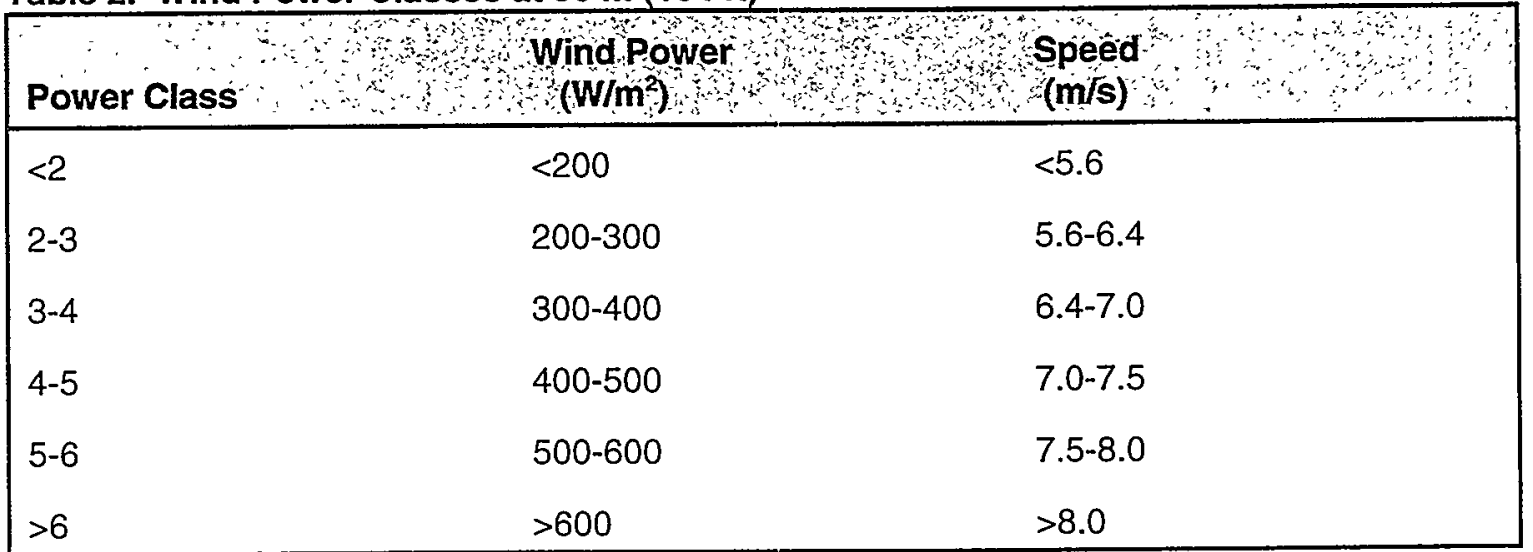

Source: Elliott and Schwartz (1997). 
To assess the viability of development at specific CEC sites and to estimate the sizes of resources, when necessary, digital elevation models (DEM), which are digital records of terrain elevations for ground positions at regularly spaced horizontal intervals, were obtained. DEMs are developed from stereo models or digital contour line files derived from the U.S. Geological Survey (USGS) topographic quadrangle maps and provided by the USGS (USGS 1990). We processed the DEMs to create GIS surface lattices and contour line coverages. Using contour lines as a backdrop, we were able to place the CEC sites on our maps, following ridge lines and general topography.

Relief maps in the vicinity of the wind sites were then produced. Relief maps were constructed from DEMs. Major roads, rivers, lakes, and transmission lines are shown on the relief maps (Figures 4 through 15). Rivers and lakes were obtained from the ESRI-ArcUSA data set. Again, wind sites are marked by the hub on the windmill symbol. We then used GIS to calculate distances from the wind sites to roads and transmission lines.

Figure 4. Walker Ridge

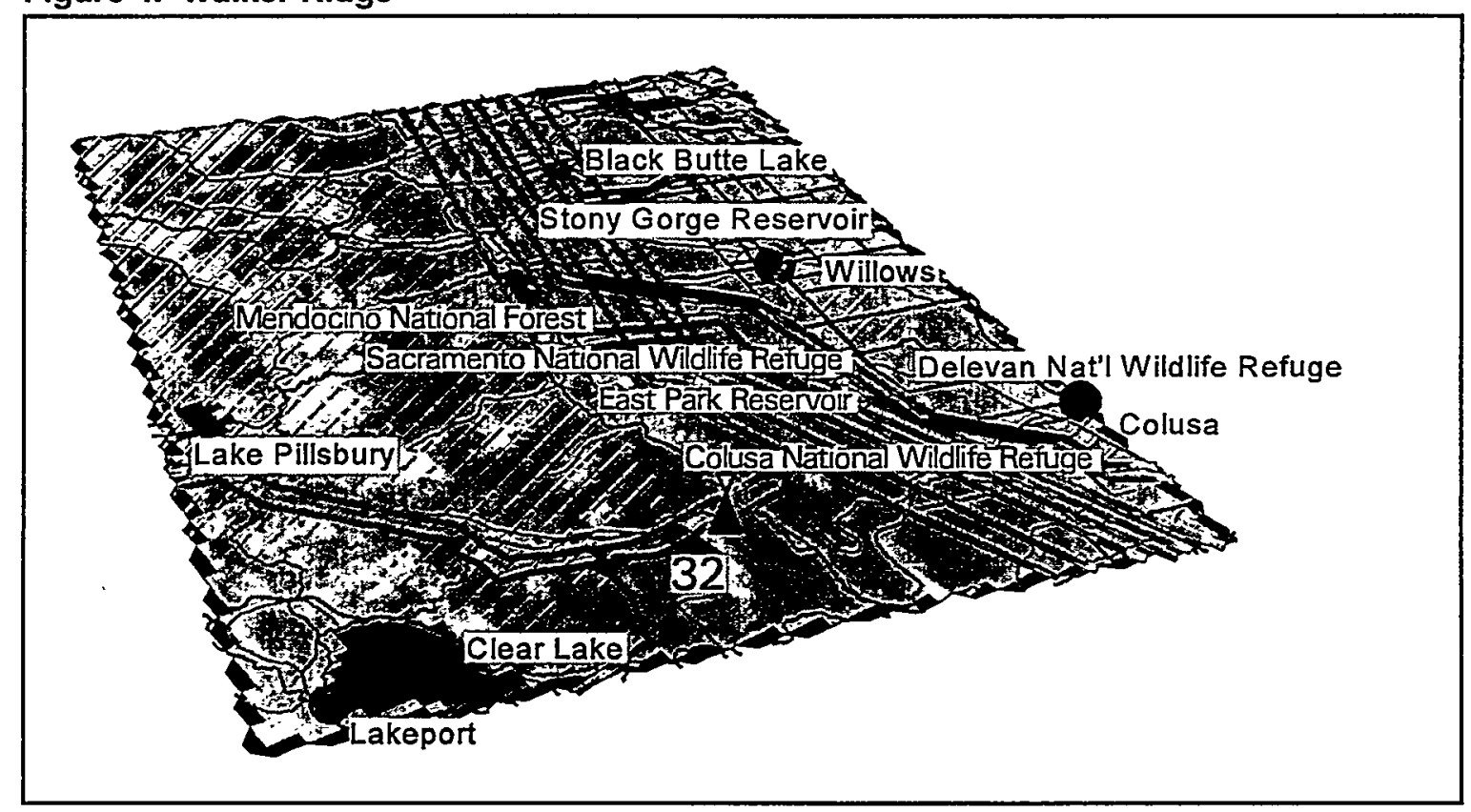

Data from USGS, ESRI, and FEMA 
Figure 5. Bear River Ridge

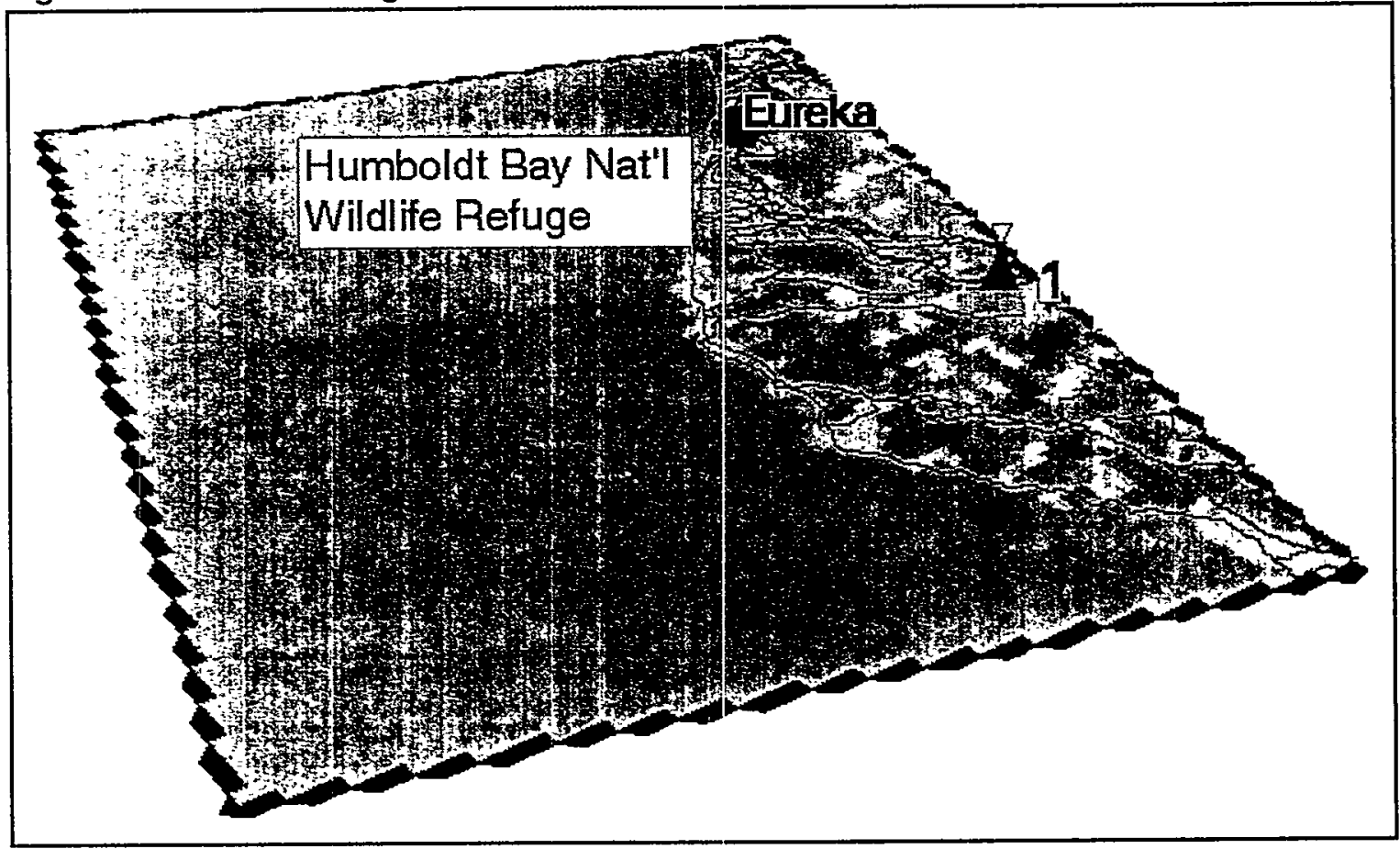

Data from USGS, ESRI, and FEMA

Figure 6. Potrero Hills

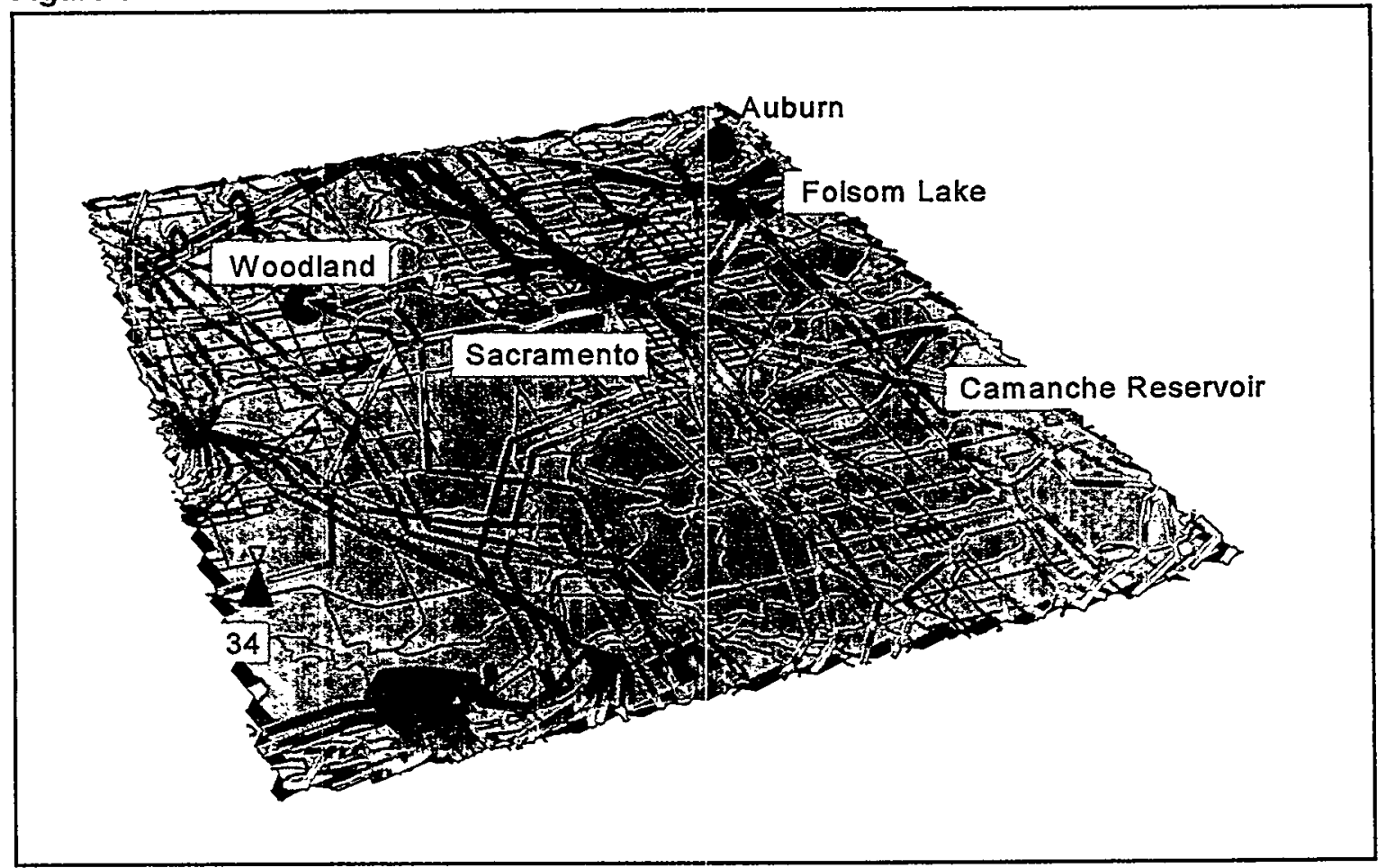

Data from USGS, ESRI, and FEMA 
Figure 7. West San Jose Area

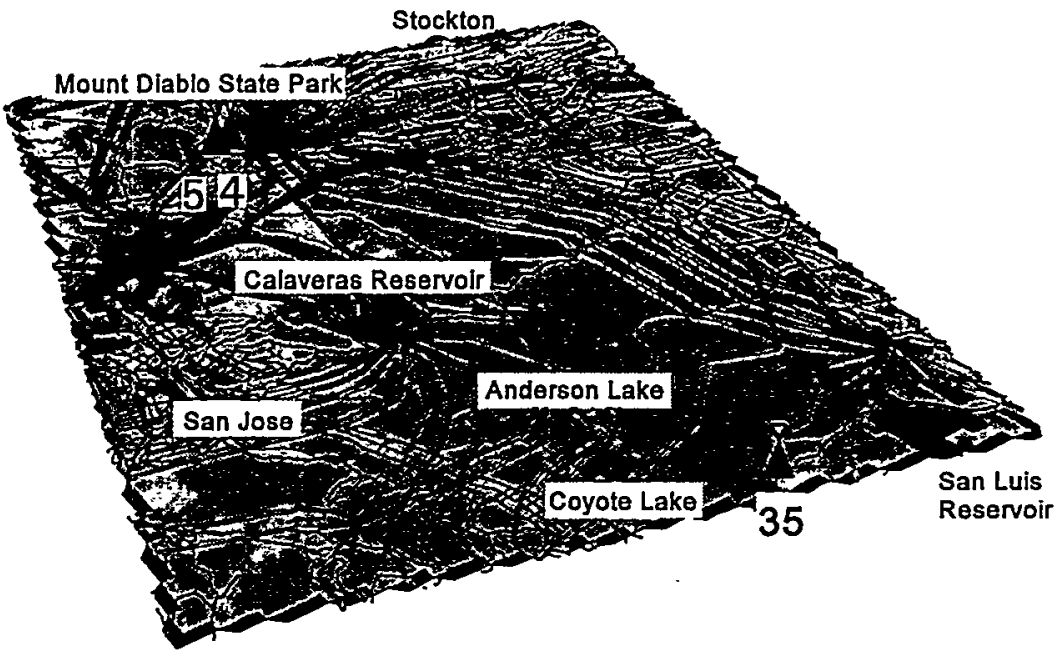

Data from USGS, ESRI, and FEMA

Figure 8. West San Bernardino Area

Data from USGS, ESRI, and FEMA 
Figure 9. East Bakersfield Area

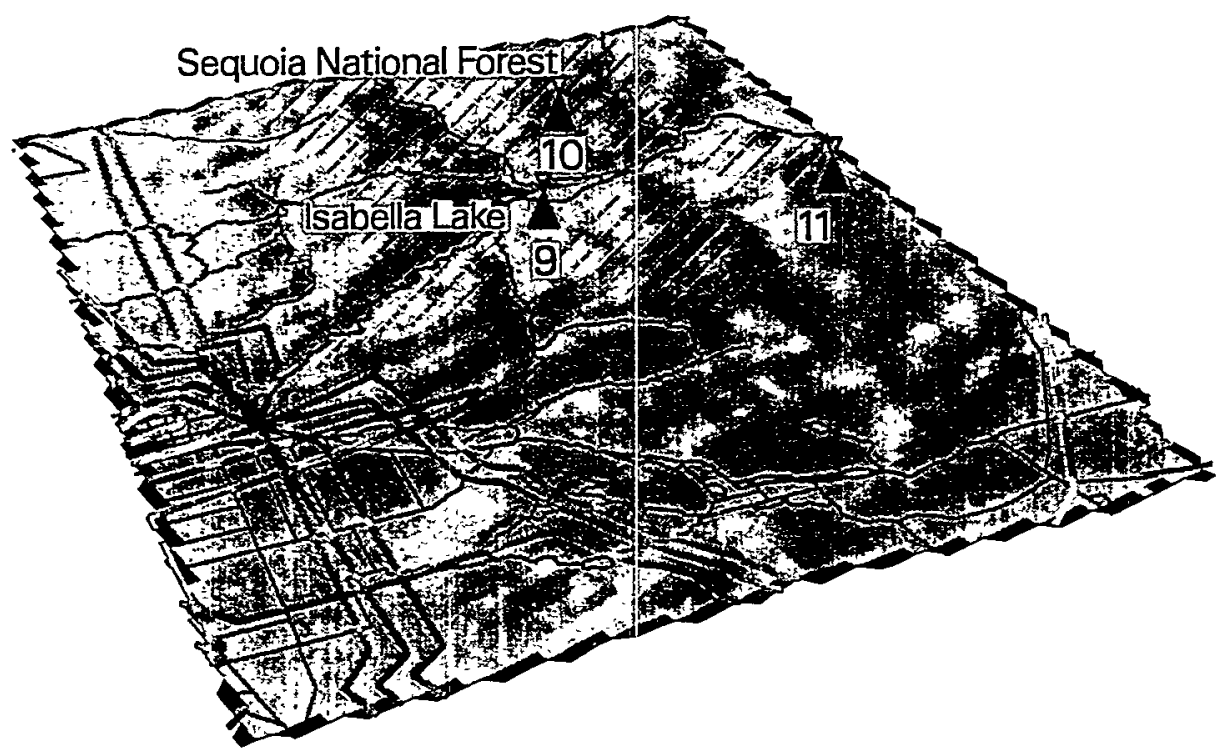

Data from USGS, ESRI, and FEMA

Figure 10. East San Bernardino Area

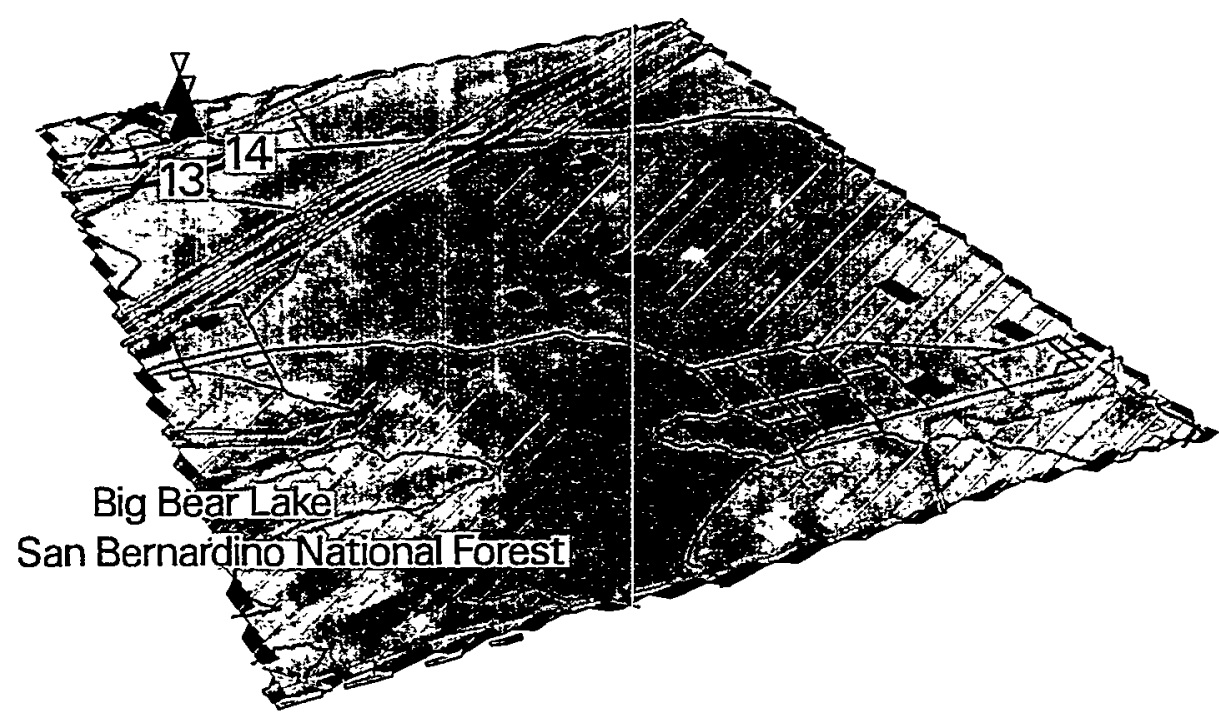

Data from USGS, ESRI, and FEMA 
Figure 11. East Santa Ana Area

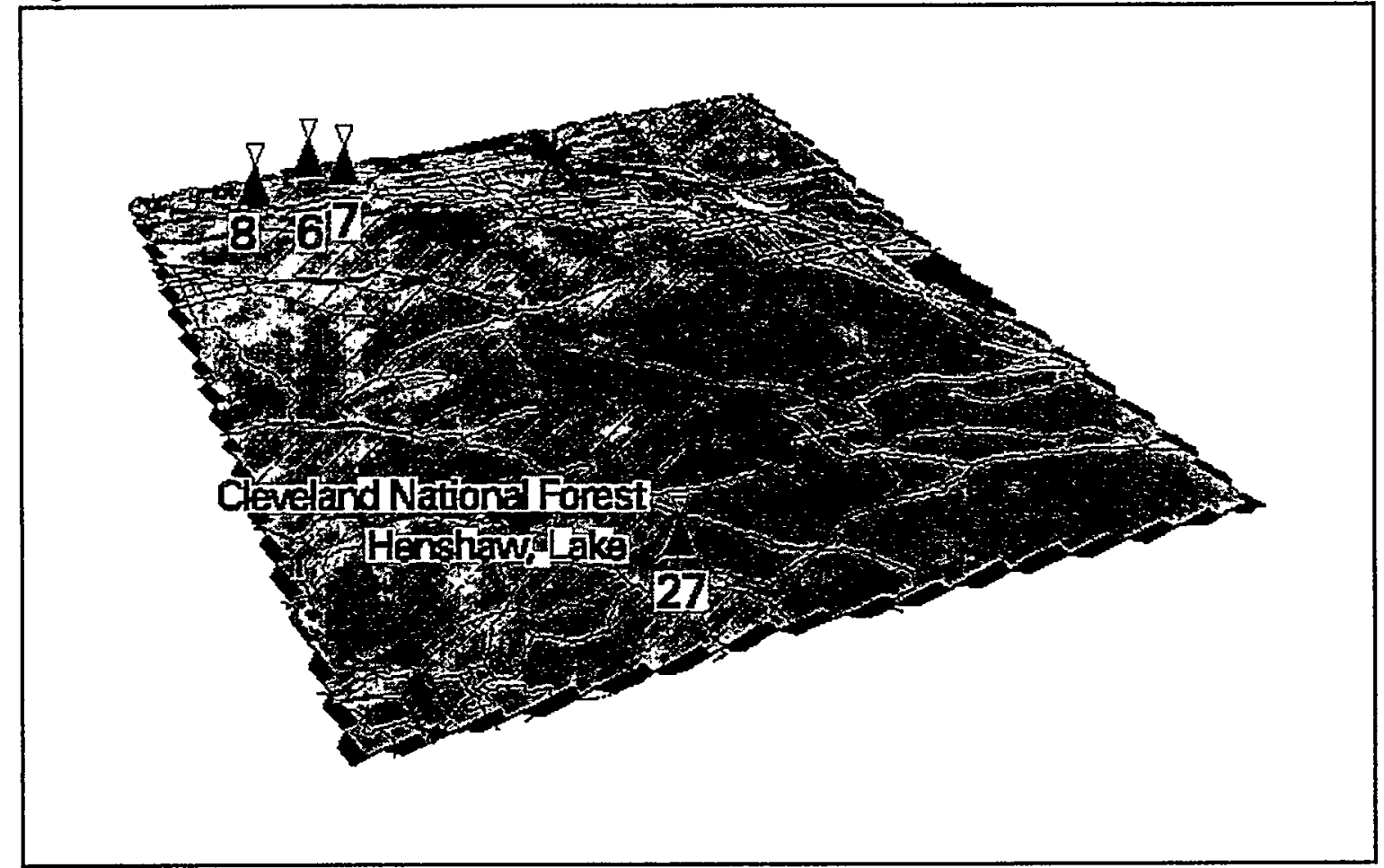

Data from USGS, ESRI, and FEMA

Figure 12. East San Luis Obispo

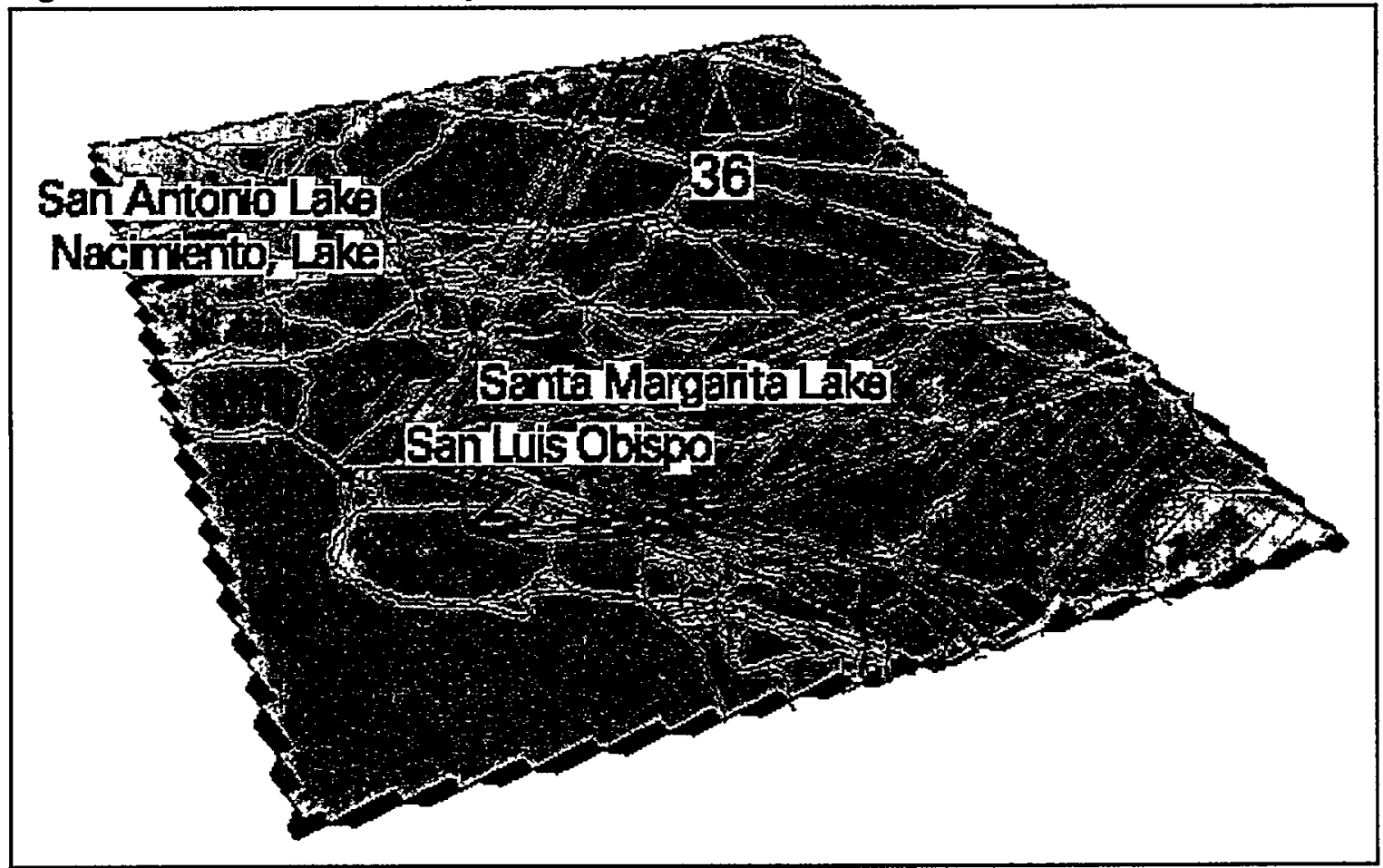

Data from USGS, ESRI, and FEMA 
Figure 13. West Kingman Area

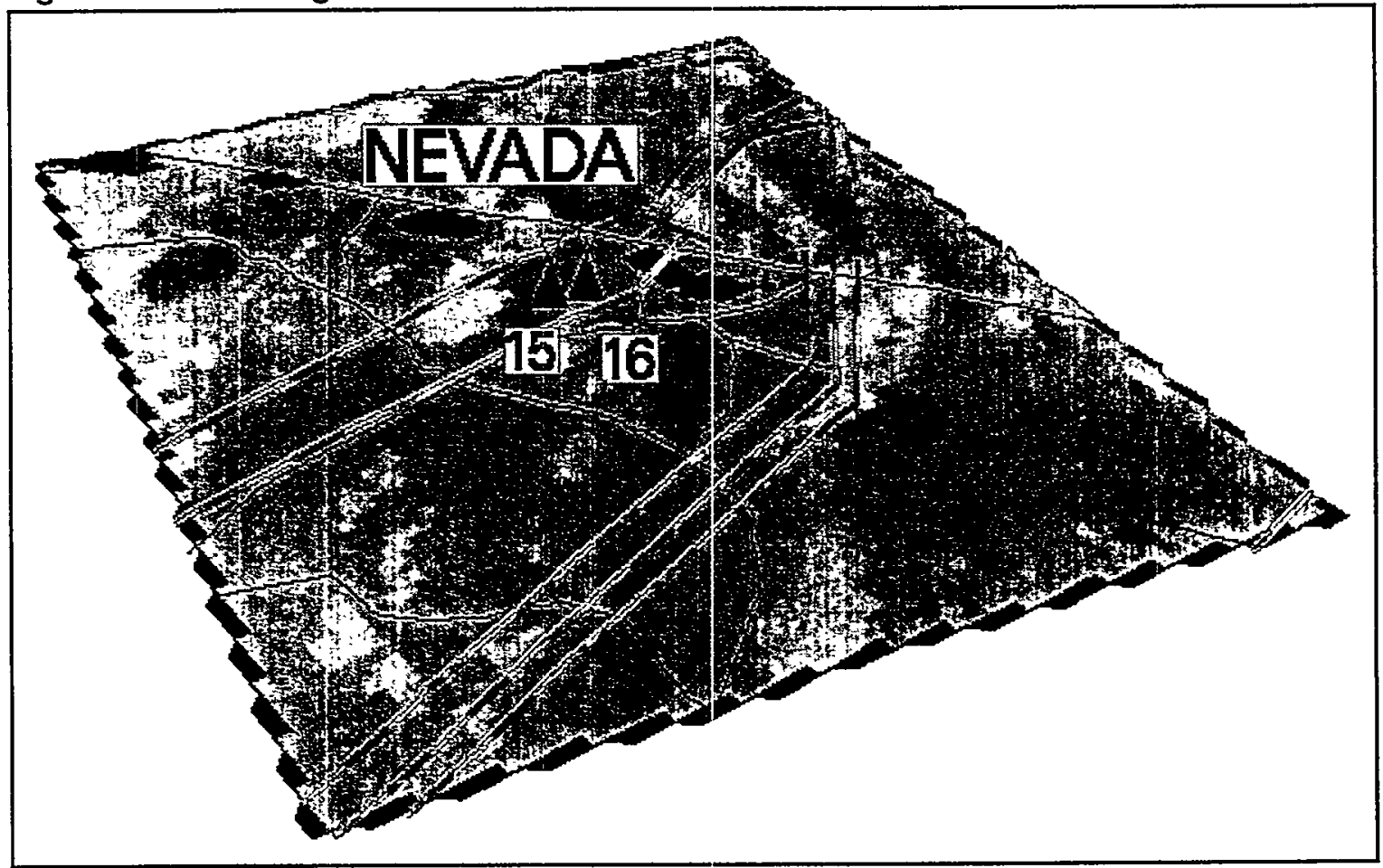

Data from USGS, ESRI, and FEMA

Figure 14. East Los Angeles Area

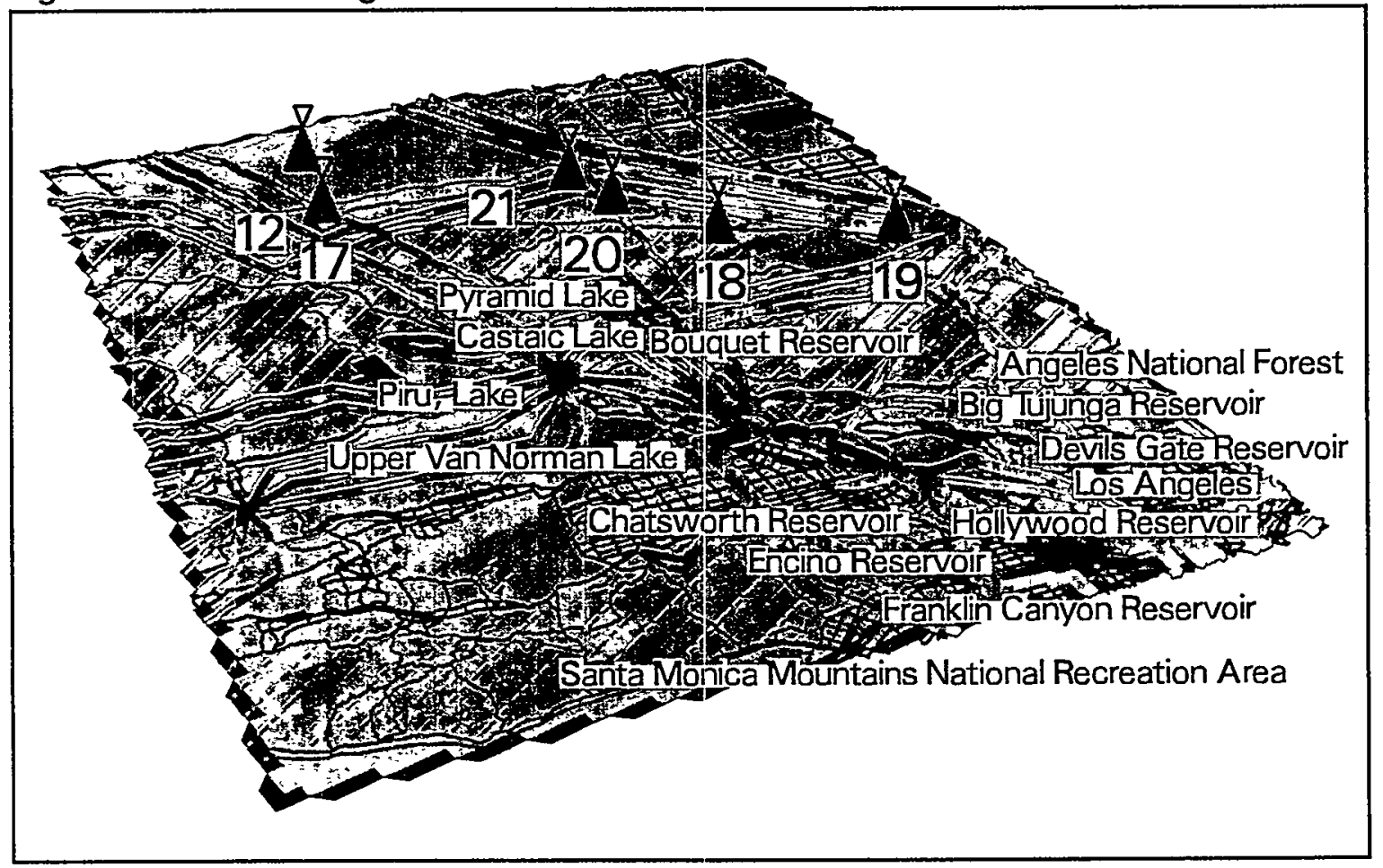

Data from USGS, ESRI, and FEMA 
Figure 15. East San Diego Area

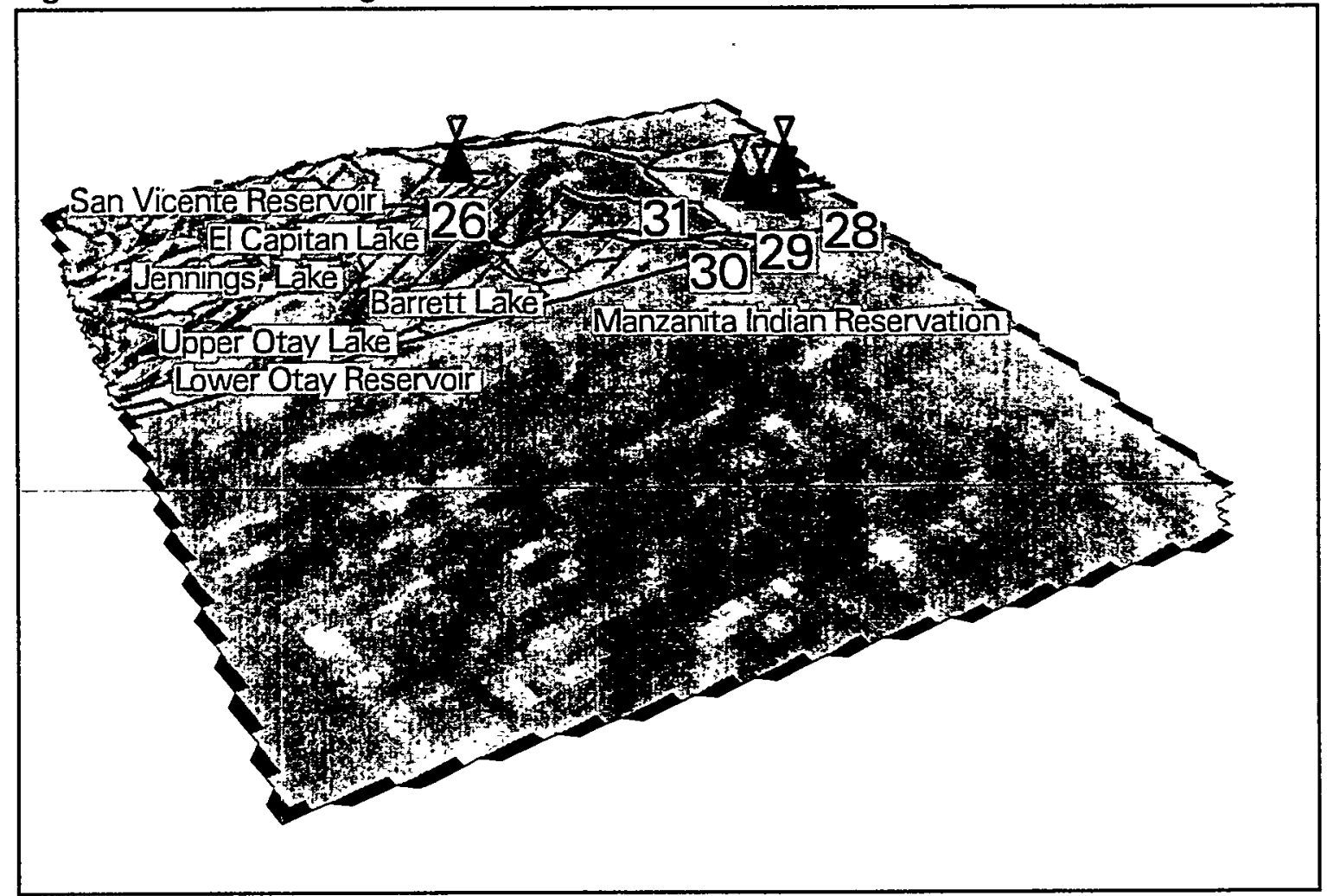

Data from USGS, ESRI, and FEMA 


\section{Choice of Technology and Cost Function}

The typical size of wind generators commercially used has grown from $12.5-\mathrm{m}$ rotor diameter in the early 1980s to 40-m diameter in the mid 1990s. A modern 40-m rotor diameter wind turbine typically corresponds to $0.5 \mathrm{MW}$ of capacity. It is likely that during the next thirty years, due to improvements in design, 0.75 - to $1-\mathrm{MW}$ generators will be used more. However, the very large ( 1.5 to $3 \mathrm{MW}$ ) generators which were developed by funding from U.S., German, and British wind programs have not yet achieved commercial viability.

Experience of the last two decades shows that increasing size does not necessarily decrease generator costs per $\mathrm{kW}$ capacity, although the larger size does provide a scale economy related to operating and maintenance costs. The cost of servicing a wind generator is the same for all generators which are less than $50 \mathrm{~m}$ in diameter. For larger turbines, large cranes are needed for most repairs which increases maintenance costs and, possibly, some first costs such as construction of wider access roads.

In this study, we used a prototypical 0.5-MW (40-m rotor diameter, 50-m hub height) turbine in evaluating the sites. This follows from the argument that such a size is big enough to sweep a large area and yet small enough to keep the maintenance costs low. It also appears that the industry has been evolving in that general direction.

Contributors to the initial cost of a wind plant are the cost of the generators, the cost of the land where the generator is erected (this is generally quite small), costs associated with connecting the individual generators to the grid, and costs of building access roads. Operating costs include: maintenance costs, rents for the areas covered by the wind farm, and labor costs. In this study, using digital elevation maps to determine wind sites, resulted in an improved methodology for quantifying the distance to existing transmission lines and roads. Detailed estimation of the unit costs for the items listed above was not one of the main objectives of this study. However, information available in existing studies was incorporated in the cost calculations. Clearly, cost estimates could be improved by refining the unit cost based on recent surveys of equipment costs, land values, land rental rates, road construction costs, etc. Other factors such as proximity to other wind farms and population centers could also be included in the estimation. 


\section{Wind Power Plant Capital Outlay ${ }^{6}$}

\section{Wind Turbine Generators ${ }^{7}$}

The trends in published transaction costs (cost plus profit) for wind power projects show that the price paid for wind power plants in California and Denmark fell dramatically in the 1980s (Gipe 1995). In California, the price in 1992 dollars came down from $4000 \$ / \mathrm{kW}$ in 1981 to $1200 \$ / \mathrm{kW}$ in 1987. NREL (1996) estimates the 1994 costs in the range 800 to 1000 $\$ / \mathrm{kW}$. The cost used by Union of Concerned Scientists based on prices they obtained from US Windpower is $1032 \$ / \mathrm{kW}$ for a 50-MW wind farm in the Midwest in 1992 dollars (Brower et al. 1993). In this study we used a cost of $1000 \$ / \mathrm{kW}$. This cost is reduced by about one percent every year into the future. This figure includes the equipment, construction costs, land, and permits.

\section{Connecting to the Grid $^{8}$}

It is assumed that the wind farms would be connected to the grid through a substation. The line between the substation and the grid would be a high voltage line, typically $115 \mathrm{kV}$. Transmission lines from the substation to the grid will require 100000 to $130000 \$ / \mathrm{km}$ depending on the terrain and a fixed hookup charge of $\$ 300000$. Within the site, turbines are assumed to be connected to the substation by low voltage lines of $4.16 \mathrm{kV}$ at a cost of $50000 \$ / \mathrm{kW}$. For each site, a $\$ 3000000$ substation charge is assumed.

\section{Access Roads ${ }^{9}$}

All weather access is required by maintenance crews. These roads also need to be built such that heavy equipment can be moved to the sites during construction. For this study 4-m (about $12 \mathrm{ft}$ ) wide roads are assumed necessary. The construction of roads are assumed to cost $22000 \$ / \mathrm{km}$. For the land covered by the roads, a one-time cost of $375000 \$ / \mathrm{km}^{2}$ (\$1 500 per acre) is assumed.

$6 \quad$ All costs and revenues are in 1995 dollars.

$7 \quad$ cost of generators $=$ generation capacity $(\mathrm{kW}) \times 1000 \$ / \mathrm{kW}$

8 cost of connecting to the grid $=\$ 300000$ hookup charge $+130000 \$ / \mathrm{km} \times$ distance to transmission lines $(\mathrm{km})+50000 \$ / \mathrm{km} \times$ lines within farm $(\mathrm{km})+\$ 3000000$ substation cost

9 cost of connecting to the roads $=[22000 \$ / \mathrm{km} \times$ distance to roads $(\mathrm{km})]+\left[\right.$ land value $\left(\$ / \mathrm{km}^{2}\right)$ $\times 0.006 \mathrm{~km}^{2} / \mathrm{km}$ land requirement $\times$ distance to roads $(\mathrm{km})$ ] 


\section{Operating Costs}

\section{Maintenance Costs ${ }^{10}$}

Maintenance costs compiled by Gipe (1995) indicate that they are about $0.012 \$ / \mathrm{kWh}$ in 1992 currency. For some sites this may be substantially lower or higher. For this study we use $0.012 \$ / \mathrm{kWh}$.

\section{Land Rent ${ }^{I I}$}

Wind turbines occupy only a small fraction of the land area they are built over. Usually, the area can still be used for farming or grazing animals. In California, much of the sites are either on ridges or areas which are only suitable for grazing. The major exception is the Palm Springs-Whitewater area which is mostly rural residential. In this study, we use a cost of $10000 \$ / \mathrm{km}^{2}$ (\$40 per acre) per year in all areas except the Palm Springs-Whitewater area. For the Palm Springs area, we use $25000 \$ / \mathrm{km}^{2}$ ( $\$ 100$ per acre) per year. It is assumed that each $500-\mathrm{kW}$ windmill will require an area of $0.04 \mathrm{~km}^{2}$ (10 acres), which is based on the generator-spacing assumptions covered in the next section.

11 rent for the wind farm $=$ rent $\left(\$ / \mathrm{km}^{2}\right) \times 0.04 \mathrm{~km}^{2} /$ wind generator $\times 2$ generators $/ 1000 \mathrm{~kW} \times$ site capacity $(\mathrm{kW})$ 


\section{Capacity and Profitability of Wind Resources}

In this section, costs and estimated revenues for wind generators at each of the selected 36 sites are processed to provide a preliminary characterization of capital costs and profitability of wind resources in California. A simple levelized cost and revenue method is used. The summary section of the spreadsheet which serves as the database for the information on these sites is presented in Appendix A.

\section{Characterization of the Wind}

For each of the 36 sites selected, diurnal wind speeds (typically recorded every 3 hours) for four seasons (winter, spring, summer, and autumn), monthly average wind speeds, and annual average wind speeds are developed, based on the data collected in the CEC and DOI studies. Wind data are available for many of the sites at the above level of detail: The exceptions are the sites on the coastal mountains and in San Diego county. For these locations, diurnal average wind patterns are available either only for the whole year or only for winter and summer (as opposed to four seasons). On the other hand, for some of the other sites, there are hourly chronological data for more than one year. Data for the different sites are not necessarily coincident. They are typically for a year during the late 1970s or early 1980s. It is noted that sites with similar annual average wind speeds may have very different seasonal and diurnal patterns. Wind patterns for selected sites are presented in Figures A-1 to A-5 in Appendix A.

\section{Estimation of Power}

As mentioned above, for this study, a generic wind turbine of 40-m diameter and 50-m hub height is used. The wind speed at $10 \mathrm{~m}$ is used to estimate the wind speed at $50 \mathrm{~m},{ }^{12}$ and similar wind profiles for each of the locations are assumed, for lack of detailed information.

The power coefficient of a wind turbine is defined as the power delivered by the generator divided by the total power available in the cross-sectional area of the wind stream spanned by the blades. The maximum value for the power coefficient for the optimal blade design is 0.593 . In practice, windmills can achieve power coefficients in the range of 0.4 to 0.45 (Eldridge 1975), and in this study we assumed a power coefficient of 0.45 .

Given the above assumptions, the wind patterns for the sites in consideration are converted into potential power patterns.

12

using the formula $\left(V_{50} / V_{10}\right)^{7}=(50 / 10)$; where $V_{50}=$ wind velocity at $50 \mathrm{~m}$ and $V_{10}=$ wind velocity at $10 \mathrm{~m}$ 


\section{Estimation of Revenues by Spreadsheet}

The results of Elfin simulations are reported below, but a preliminary spreadsheet analysis of wind site profitability was conducted as follows. Elfin models the market and delivers results for both capacity expansion and dispatch. Electricity prices depend on what kinds of wind resources are built, and how they are dispatched. In other words, decisions about wind turbines and electricity prices are endogenous to the model. However, since the wind resources are small compared to other generating assets, we may assume that decisions about wind generation will not affect electricity prices significantly. With this assumption, electricity prices generated by Elfin in a previous run with the generic wind resource were used. Prices are generated with a diurnal pattern for each season. Superimposing these prices with the wind data, revenues at each of the 36 locations are calculated.

\section{Estimation of Resource Capacity}

Windmills are placed (positioned) in varying styles at wind farms. How closely the mills are placed relative to each other affects the performance of the site. The optimal site design depends on many factors such as the profile of the wind, the terrain, etc. Creating designs for each site is beyond the scope of this study so the following was assumed: (1) for the ridge sites, the windmills were placed three diameters apart, and (2) for the flatter areas, windmills were again placed three diameters apart across the wind and eight diameters apart along the prevalent wind. Based on these assumptions and the sizes of the 36 sites given in the CEC and DOI studies, the potential capacity for each site was estimated. If the size of the resource is not given in the CEC or DOI reports, they are estimated using GIS.

\section{Capital-Cost and Profitability Curves}

The wind capital cost curves presented in this report (Figures 16 and 17) show the amount of annual generation at different levels of initial capital outlay in the years 2010 and 2030. The resources in these curves are ordered from the highest annual generation to the lowest, for a given amount of initial capital outlay (Tables 3 and 4). The curves show that the desirability of the resources in California at different sites vary considerably and exhibits a smooth diminishing-return to capital. It appears that, in the year 2010 , for a $\$ 8.2 \times 10^{9}$ capital investment, there is a potential generation of about $43 \mathrm{TWh} / \mathrm{a}$. The same cost goes down to $\$ 6.5 \times 10^{9}$ in the year 2030. In this study, it is assumed that the capital costs for wind development will decline at a rate of $1.15 \% / a$ during the study period. 
Figure 16. Capital Costs for California Wind Generation in 2010

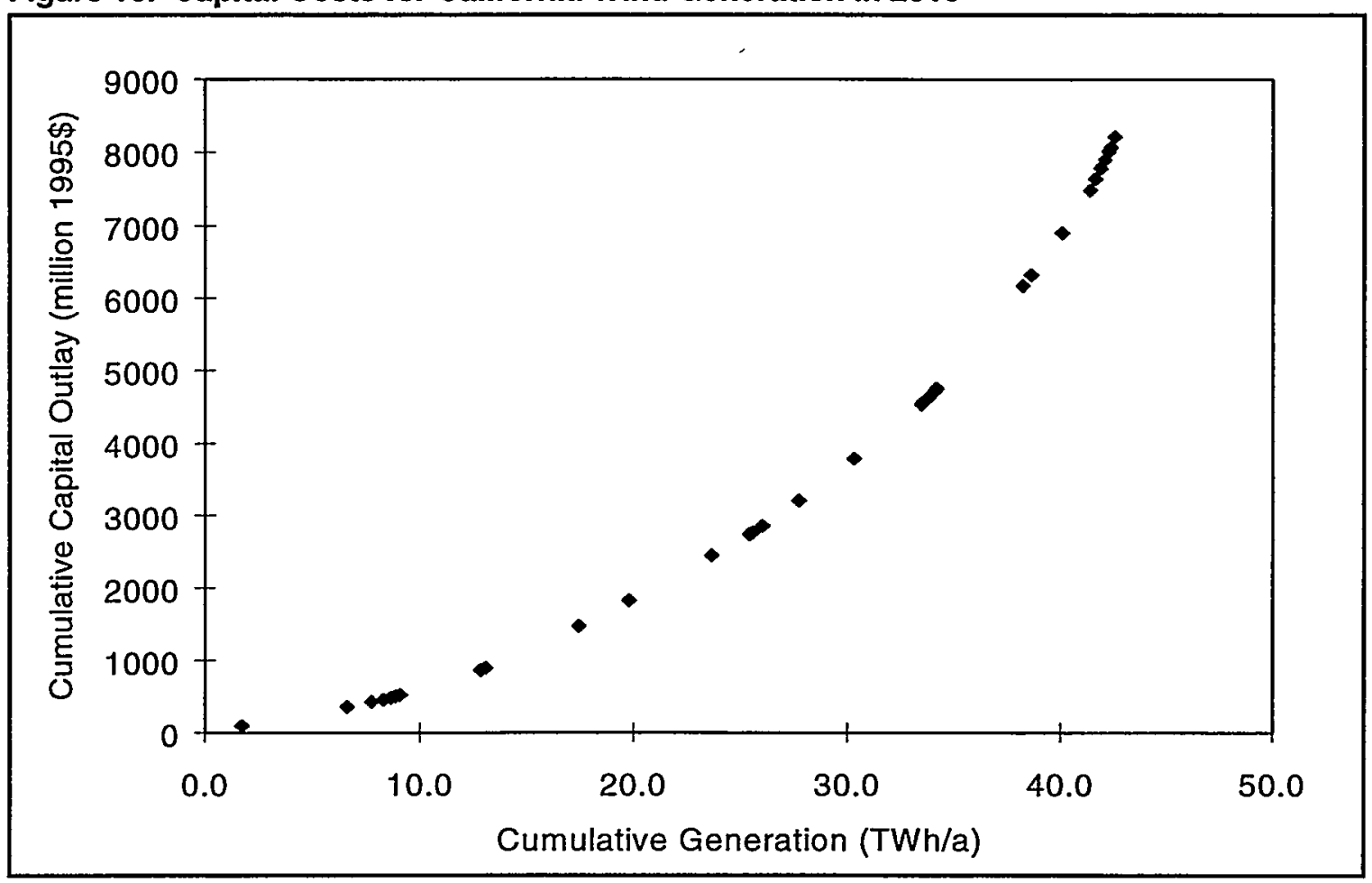

Figure 17. Capital Costs for California Wind Generation in $\mathbf{2 0 3 0}$

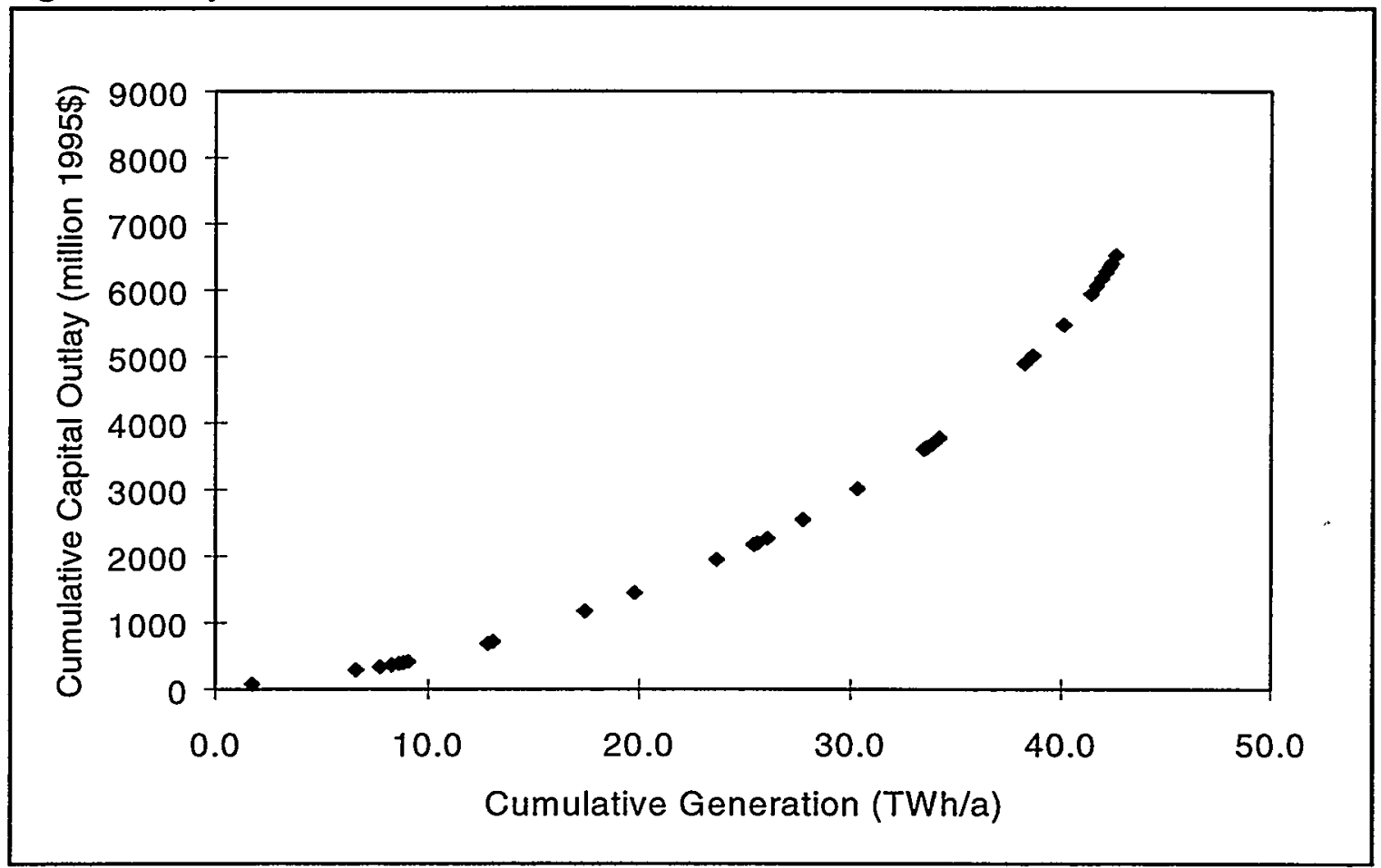


Table 3. Capital Costs Wind Generation in 2010

\begin{tabular}{|c|c|c|}
\hline Resource & $\begin{array}{c}\text { Cumulative Generation } \\
\text { (TWh/la) }\end{array}$ & $\begin{array}{l}\text { Cumulative Capital Outlay } \\
\text { (million } \$ \text { ) }\end{array}$ \\
\hline 26 & 1.7 & 92 \\
\hline 6 & 6.6 & 361 \\
\hline 27 & 7.7 & 424 \\
\hline 30 & 8.3 & 459 \\
\hline 31 & 8.6 & 485 \\
\hline 29 & 8.8 & 503 \\
\hline 28 & 9.1 & 522 \\
\hline 2 & 12.8 & 866 \\
\hline 24 & 13.1 & 897 \\
\hline 4 & 17.4 & 1476 \\
\hline 1 & 19.8 & 1826 \\
\hline 7 & 23.7 & 2449 \\
\hline 3 & 25.4 & 2735 \\
\hline 16 & 25.6 & 2767 \\
\hline 9 & 26.0 & 2853 \\
\hline 34 & 27.7 & 3204 \\
\hline 21 & 30.3 & 3786 \\
\hline 5 & 33.5 & 4542 \\
\hline 15 & 33.5 & 4551 \\
\hline 10 & 33.6 & 4575 \\
\hline 25 & 33.8 & 4635 \\
\hline 12 & 34.1 & 4719 \\
\hline 32 & 34.2 & 4751 \\
\hline 8 & 38.2 & 6171 \\
\hline 17 & 38.6 & 6318 \\
\hline 11 & 40.1 & 6903 \\
\hline 23 & 41.4 & 7486 \\
\hline 35 & 41.7 & 7634 \\
\hline 19 & 41.9 & 7782 \\
\hline 20 & 42.1 & 7900 \\
\hline 18 & 42.3 & 8006 \\
\hline 33 & 42.4 & 8067 \\
\hline 36 & 42.6 & 8216 \\
\hline
\end{tabular}


Table 4. Capital Costs of California Wind Generation in 2030

\begin{tabular}{|c|c|c|}
\hline Resource & $\begin{array}{l}\text { Cumulative Generation } \\
\text { (TWh/a) }\end{array}$ & $\begin{array}{l}\text { Cưmulative Capitál Oútlay } \\
\text { (million \$) }\end{array}$ \\
\hline 26 & 1.7 & 73 \\
\hline 6 & 6.6 & 286 \\
\hline 27 & 7.7 & 336 \\
\hline 30 & 8.3 & 365 \\
\hline 31 & 8.6 & 385 \\
\hline 29 & 8.8 & 399 \\
\hline 28 & 9.1 & 414 \\
\hline 2 & 12.8 & 688 \\
\hline 24 & 13.1 & 713 \\
\hline 4 & 17.4 & 1172 \\
\hline 1 & 19.8 & 1450 \\
\hline 7 & 23.7 & 1945 \\
\hline 3 & 25.4 & 2172 \\
\hline 16 & 25.6 & 2198 \\
\hline 9 & 26.0 & 2265 \\
\hline 34 & 27.7 & 2544 \\
\hline 21 & 30.3 & 3007 \\
\hline 5 & 33.5 & 3607 \\
\hline 15 & 33.5 & 3614 \\
\hline 10 & 33.6 & 3633 \\
\hline 25 & 33.8 & 3681 \\
\hline 12 & 34.1 & 3747 \\
\hline 32 & 34.2 & 3773 \\
\hline 8 & 38.2 & 4900 \\
\hline 17 & 38.6 & 5018 \\
\hline 11 & 40.1 & 5482 \\
\hline 23 & 41.4 & 5944 \\
\hline 35 & 41.7 & 6062 \\
\hline 19 & 41.9 & 6180 \\
\hline 20 & 42.1 & 6273 \\
\hline 18 & 42.3 & 6358 \\
\hline 33 & 42.4 & 6406 \\
\hline 36 & 42.6 & 6524 \\
\hline
\end{tabular}


We are assuming that, under the future regime, electricity prices will be tightly coupled to marginal costs. Under such circumstances, calculations given above can be taken one step further to include revenues and to calculate profitability of sites. Marginal electricity costs obtained from previous Elfin runs for California are used to evaluate the revenues for each of the sites yielding profitability estimates. Sites are ordered in terms of profitability and a profitability curves are presented in Figures 18 and 19 with information on the ordering of the sites in Tables 5 and 6, respectively. ${ }^{13}$ Figure 18 indicates that in the year 2010, up to about $26 \mathrm{TWh} / \mathrm{a}$ can be generated with positive profitability, that is, above simple break-even on costs. Figure 18 also shows the interesting suggestion that, output could be increased to about $34 \mathrm{TWh} /$ a with only a marginal loss of $0.01 \$ / \mathrm{kWh}$, and to about $40 \mathrm{TWh} / \mathrm{a}$ with a marginal loss of $0.02 \$ / \mathrm{kWh}$. Figure 19 indicates that, in the year 2030, up to about 34 TWh/a can be generated with positive profitability, and output could be increased to about $41 \mathrm{TWh} / \mathrm{a}$ with only a marginal loss of $0.005 \$ / \mathrm{kWh}$. These results do not change much if average prices rather than time-varying pool prices are used for the above analysis. This is due to the fact that pool prices are relatively constant throughout the year except for summer afternoons. The average pool prices used in this paper are shown in Figure 20.

Figure 18. Profitability of Wind Resources in 2010

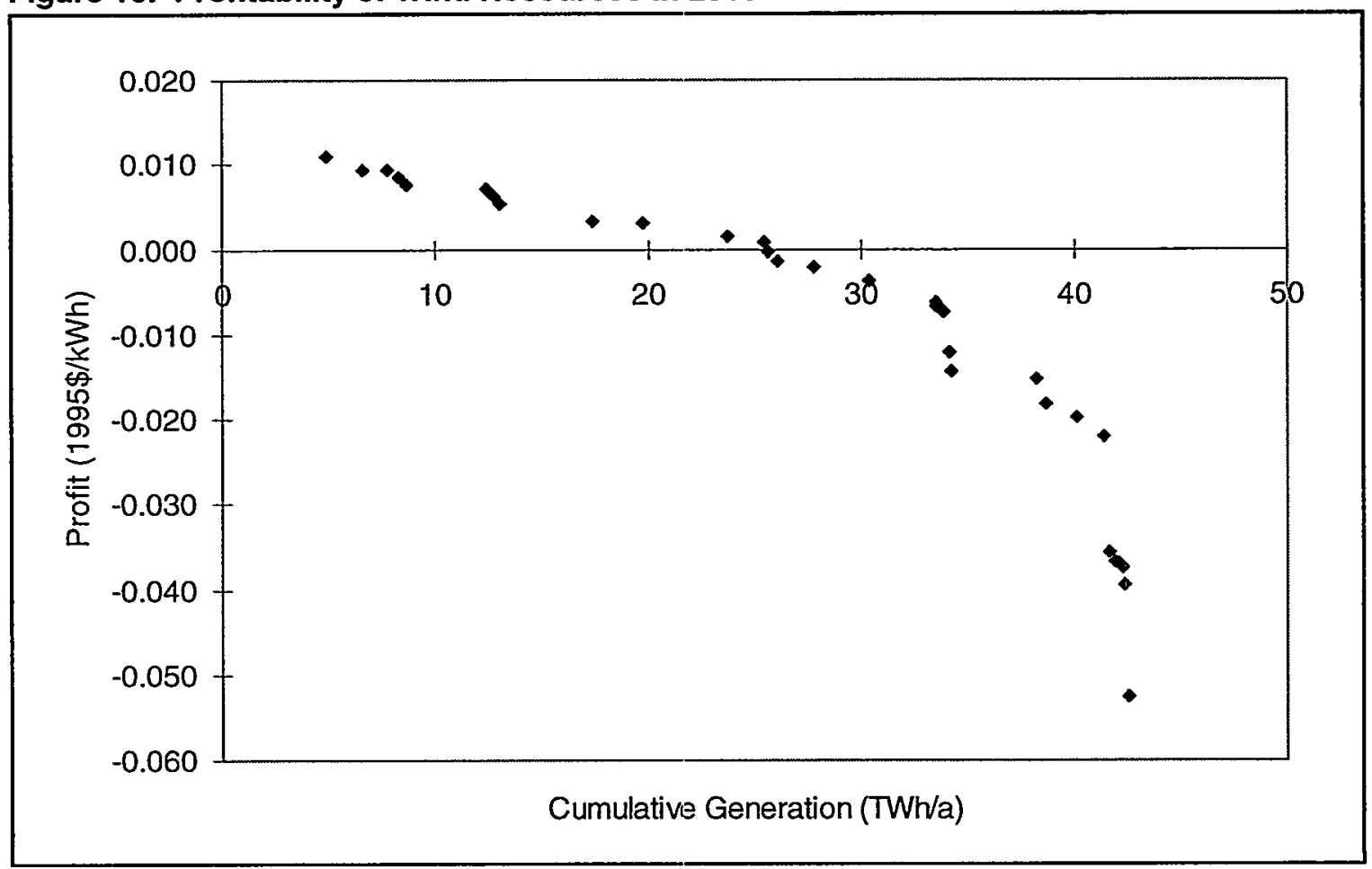
required returns on investment. 
Figure 19. Profitability of Wind Resources in 2030

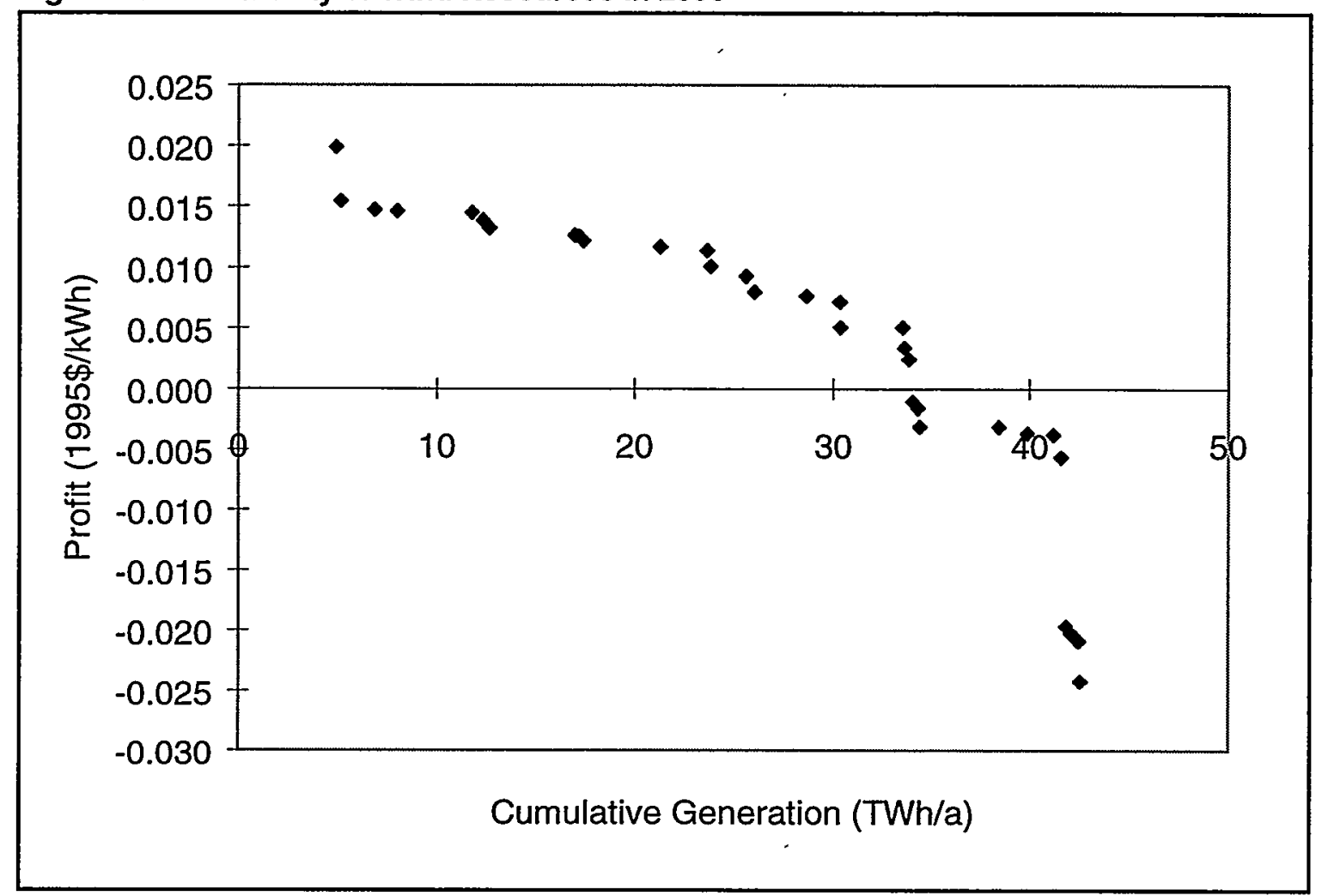


Table 5. Profitability of Wind Resources in $\mathbf{2 0 1 0}$

\begin{tabular}{|c|c|c|}
\hline Resource & $\begin{array}{c}\text { Cumulative Generation } \\
\text { (TWh/a) }\end{array}$ & Profit/kWh (\$) \\
\hline 6 & 4.881 & 0.011 \\
\hline 26 & 6.595 & 0.009 \\
\hline 27 & 7.737 & 0.009 \\
\hline 30 & 8.283 & 0.008 \\
\hline 31 & 8.626 & 0.008 \\
\hline 2 & 12.407 & 0.007 \\
\hline 29 & 12.621 & 0.007 \\
\hline 28 & 12.836 & 0.006 \\
\hline 24 & 13.075 & 0.005 \\
\hline 4 & 17.410 & 0.003 \\
\hline 1 & 19.770 & 0.003 \\
\hline 7 & 23.654 & 0.002 \\
\hline 3 & 25.410 & 0.001 \\
\hline 16 & 25.586 & 0.000 \\
\hline 9 & 26.038 & -0.002 \\
\hline 34 & 27.727 & -0.002 \\
\hline 21 & 30.322 & -0.004 \\
\hline 5 & 33.489 & -0.006 \\
\hline 15 & 33.523 & -0.007 \\
\hline 25 & 33.745 & -0.007 \\
\hline 10 & 33.842 & -0.007 \\
\hline 12 & 34.104 & -0.012 \\
\hline 32 & 34.198 & -0.014 \\
\hline 8 & 38.241 & -0.015 \\
\hline 17 & 38.625 & -0.018 \\
\hline 11 & 40.078 & -0.020 \\
\hline 23 & 41.391 & -0.022 \\
\hline 35 & 41.650 & -0.036 \\
\hline 19 & 41.898 & -0.037 \\
\hline 20 & 42.094 & -0.037 \\
\hline 18 & 42.270 & -0.037 \\
\hline 33 & 42.369 & -0.040 \\
\hline 36 & 42.563 & -0.053 \\
\hline
\end{tabular}


Table 6. Profitability of Wind Resources in $\mathbf{2 0 3 0}$

\begin{tabular}{|c|c|c|}
\hline Resource & $\begin{array}{c}\text { Cumulative Generation: } \\
\text { (Twh/a) }\end{array}$ & Profit/kWh-(\$) \\
\hline 6 & 4.881 & 0.020 \\
\hline 24 & 5.120 & 0.015 \\
\hline 26 & 6.834 & 0.015 \\
\hline 27 & 7.976 & 0.015 \\
\hline 2 & 11.758 & 0.014 \\
\hline 30 & 12.303 & 0.014 \\
\hline 31 & 12.646 & 0.013 \\
\hline 4 & 16.982 & 0.013 \\
\hline 29 & 17.196 & 0.013 \\
\hline 28 & 17.410 & 0.012 \\
\hline 7 & 21.294 & 0.012 \\
\hline 1 & 23.654 & 0.011 \\
\hline 16 & 23.830 & 0.010 \\
\hline 3 & 25.586 & 0.009 \\
\hline 9 & 26.038 & 0.008 \\
\hline 21 & 28.633 & 0.008 \\
\hline 34 & 30.322 & 0.007 \\
\hline 15 & 30.357 & 0.005 \\
\hline 5 & 33.523 & 0.005 \\
\hline 10 & 33.620 & 0.003 \\
\hline 25 & 33.842 & 0.002 \\
\hline 36 & 34.036 & -0.001 \\
\hline 12 & 34.298 & -0.002 \\
\hline 32 & 34.392 & -0.003 \\
\hline 8 & 38.435 & -0.003 \\
\hline 11 & 39.888 & -0.004 \\
\hline 23 & 41.201 & -0.004 \\
\hline 17 & 41.585 & -0.006 \\
\hline 35 & 41.844 & -0.020 \\
\hline 19 & 42.092 & -0.020 \\
\hline 20 & 42.288 & -0.020 \\
\hline 18 & 42.464 & -0.021 \\
\hline 33 & 42.563 & -0.024 \\
\hline
\end{tabular}


Figure 20. Average Pool Price for California

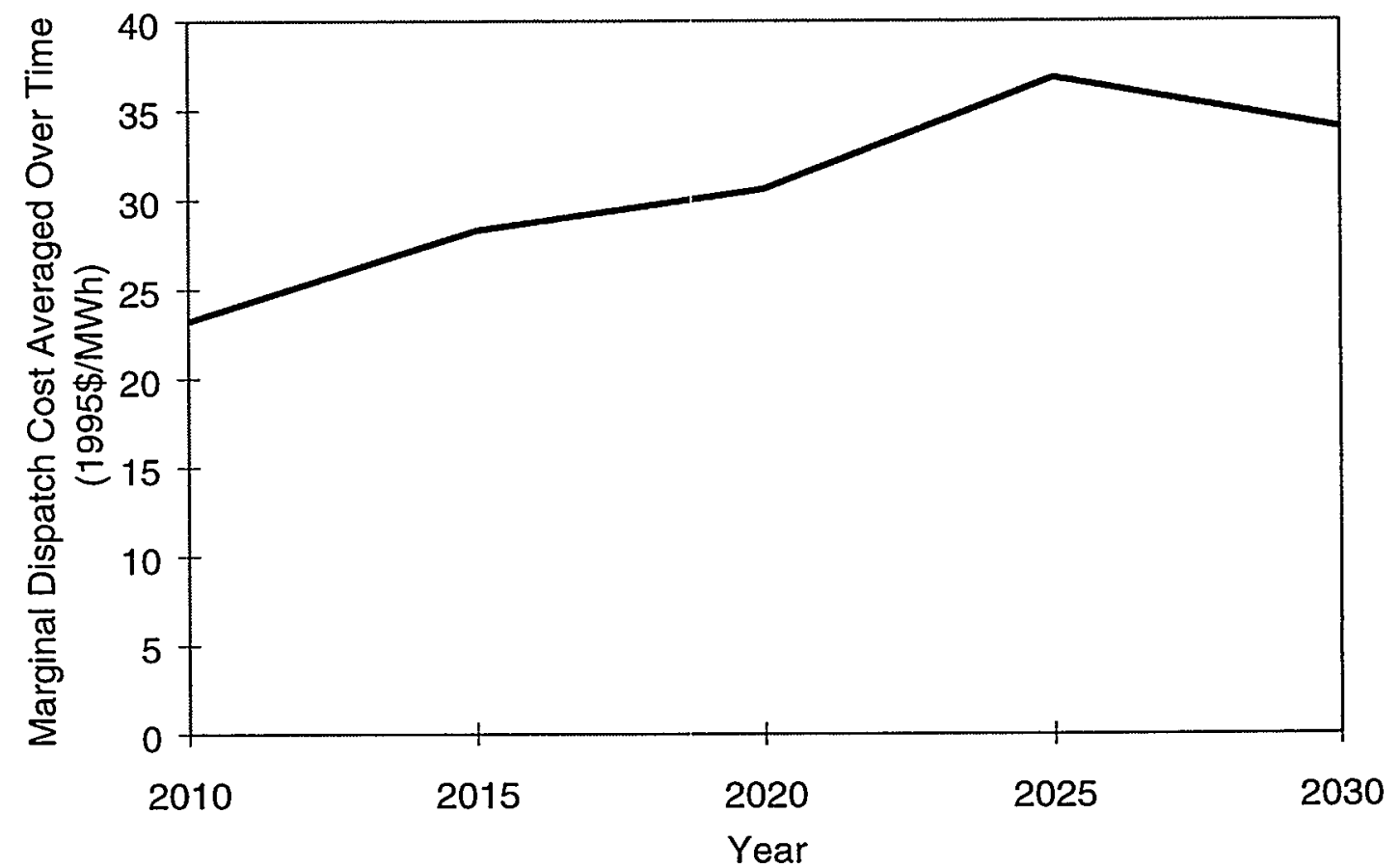




\section{Analysis Using the Elfin Model}

Calculations behind the capital cost and profitability curves do not take into account some interactions that Elfin simulates. Two of the factors that simple levelized cost analyses ignore are: (1) the effect of wind generation on pool prices, and (2) timing decisions about when to build. More accurate analysis is possible by incorporating the cost and wind resource data directly in the Elfin model and actually simulating the capacity expansion and dispatch patterns through time.

\section{Implementation}

As described above, cost, performance, and potential were estimated for the $36 \mathrm{CEC}$ sites. Ultimately, each of the sites was entered into the Berkeley Lab's Elfin data set of the California power market post 2005. The existing generation capacities in Altamont Pass, Solano Hills, Tehachapi Pass, Pacheco Pass, and San Gorgonio are deducted from the potential capacity at these sites.

Each of the sites is characterized by a development cost, a maximum capacity and rate of development, and a description of the wind resource by season and time period. Appendix B shows an example data set for one site. A prototypical wind farm of $50 \mathrm{MW}$ was used. Many of the locations can accommodate several of these 50-MW facilities.

\section{Results}

\section{Previous Results with Generic Wind Resources}

In previous Berkeley Lab studies, a generic wind farm was used in Elfin to model all the California wind potential (Marnay et al. 1998). In a best-guess scenario where the gas prices increase (in real terms) at a rate of $1.5 \% / \mathrm{a}$, wind capital cost declines at a rate of $1.15 \% / \mathrm{a}$, no wind development and generation occurs, as shown by Figures 21 and 22 respectively. Results of an Elfin run under favorable conditions (where the natural gas prices increase by $3 \% / a)$ for wind development are shown in Figures 23 and 24. Clearly, this scenario does not represent a conventional wisdom future, but rather one contrived to result in extensive wind development. The limitations of this approach are clearly evident in Figure 23. After 2017, wind becomes cheaper than repowers under the assumptions of this simulation, and in fact becomes the only technology built thereafter. Clearly, this result is unrealistic. While some wind capacity may be available at the assumed generic cost, this resource would quickly become exhausted and development would necessarily move to less desirable, more costly sites. In any case, the total installed capacity chosen by the Elfin model by 2030 probably exceeds reasonable estimates of the total wind resources of the state at prices within reason. 
Figure 21. Generation Expansion with Generic Wind Resources: Best-Guess Scenario

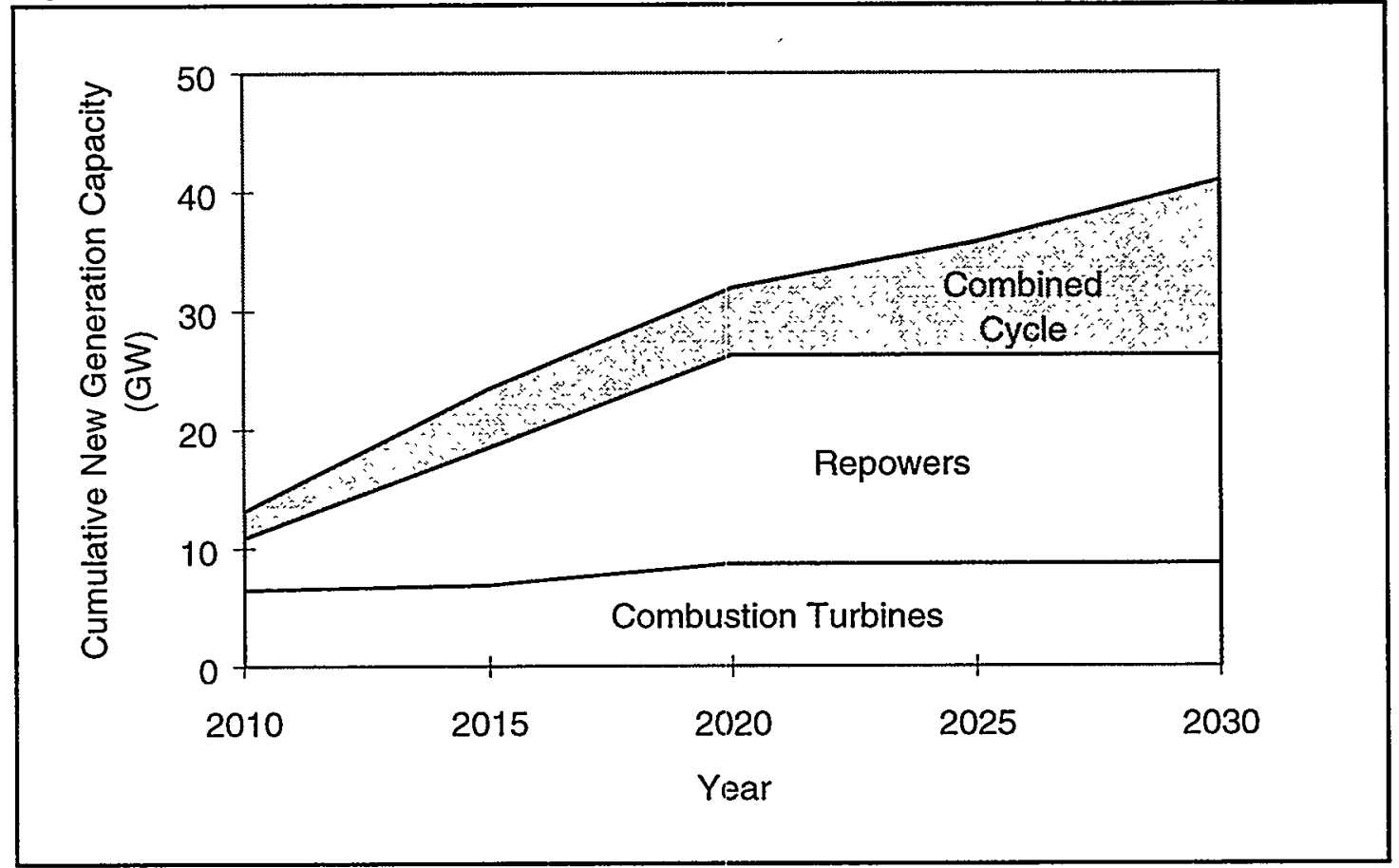

Figure 22. Generation from New Facilities with Generic Wind Resources: Best-Guess Scenario

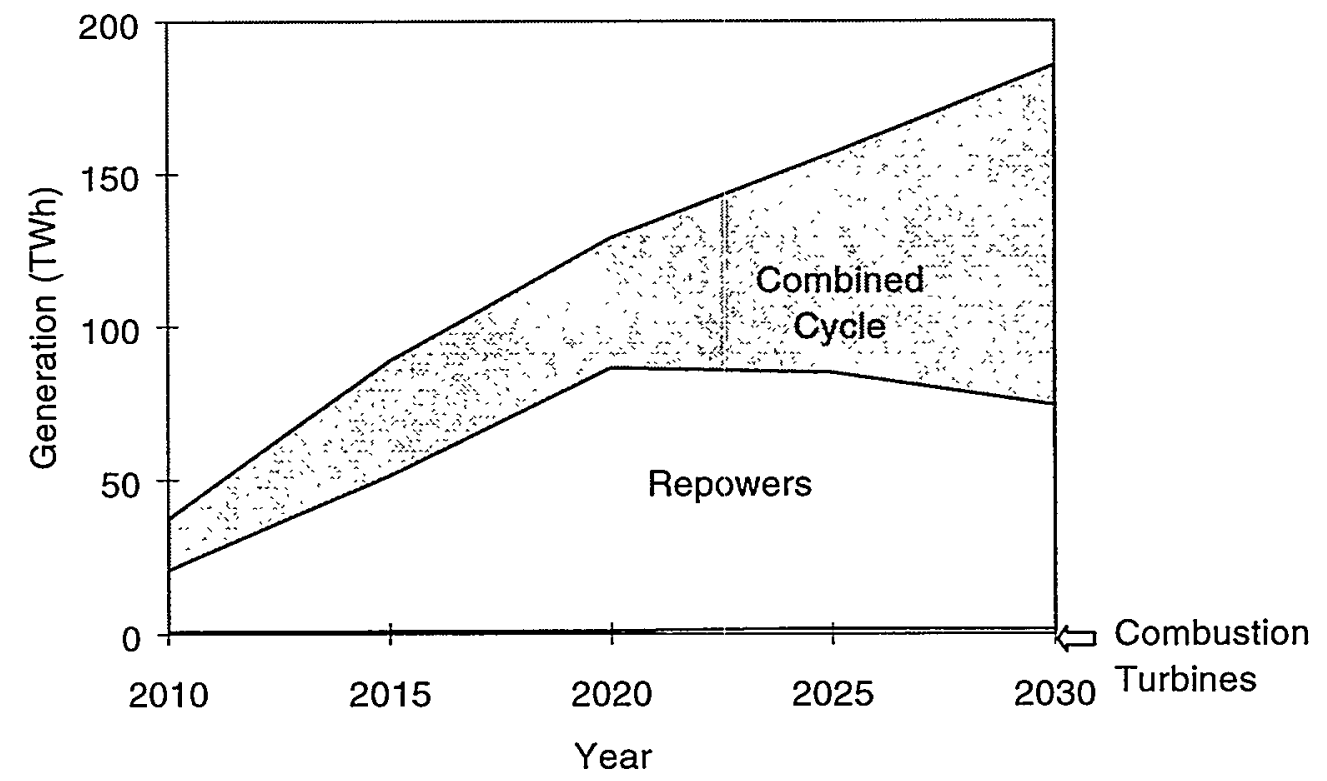


Figure 23. Generation Expansion with Generic Wind Resources: High Gas Price Scenario

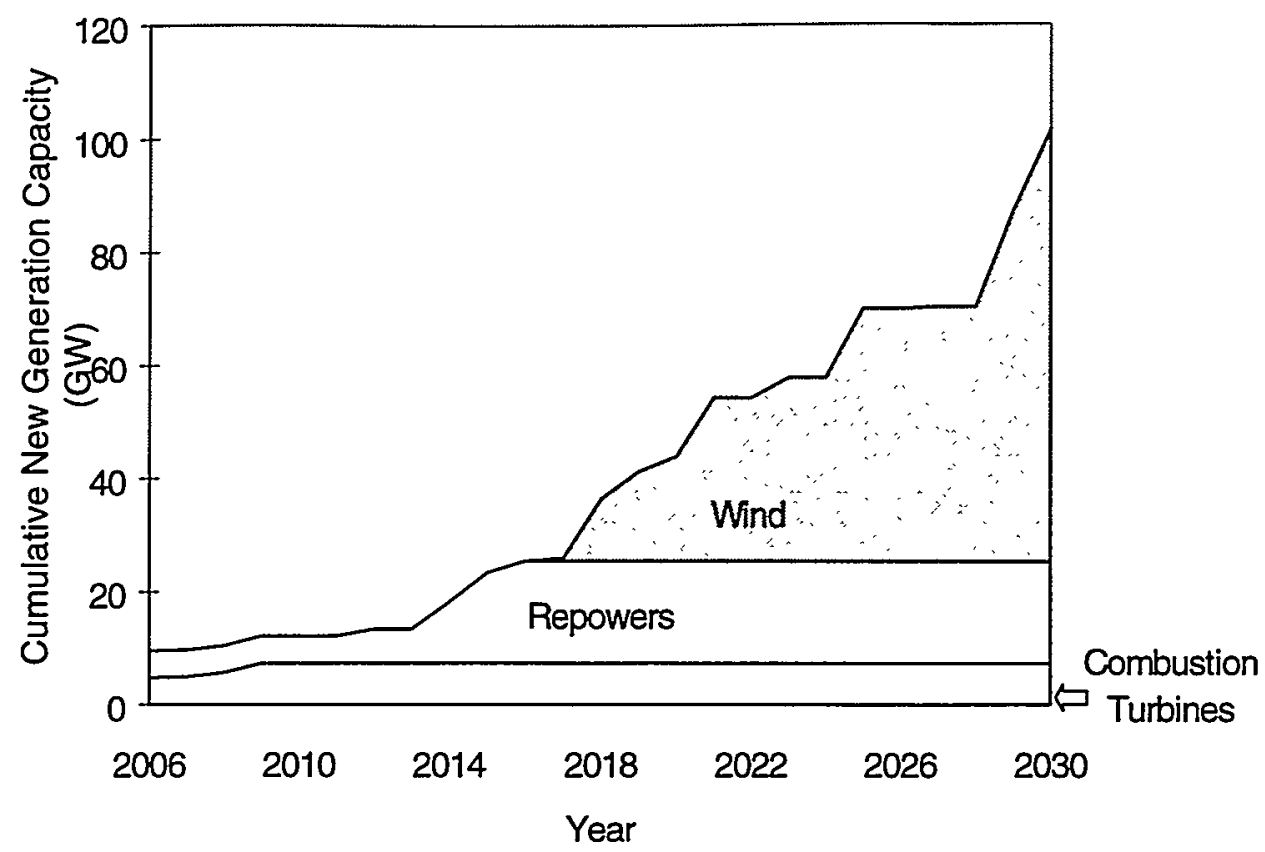

Figure 24. Generation from New Facilities with Generic Wind Resources: High Gas Price Scenario

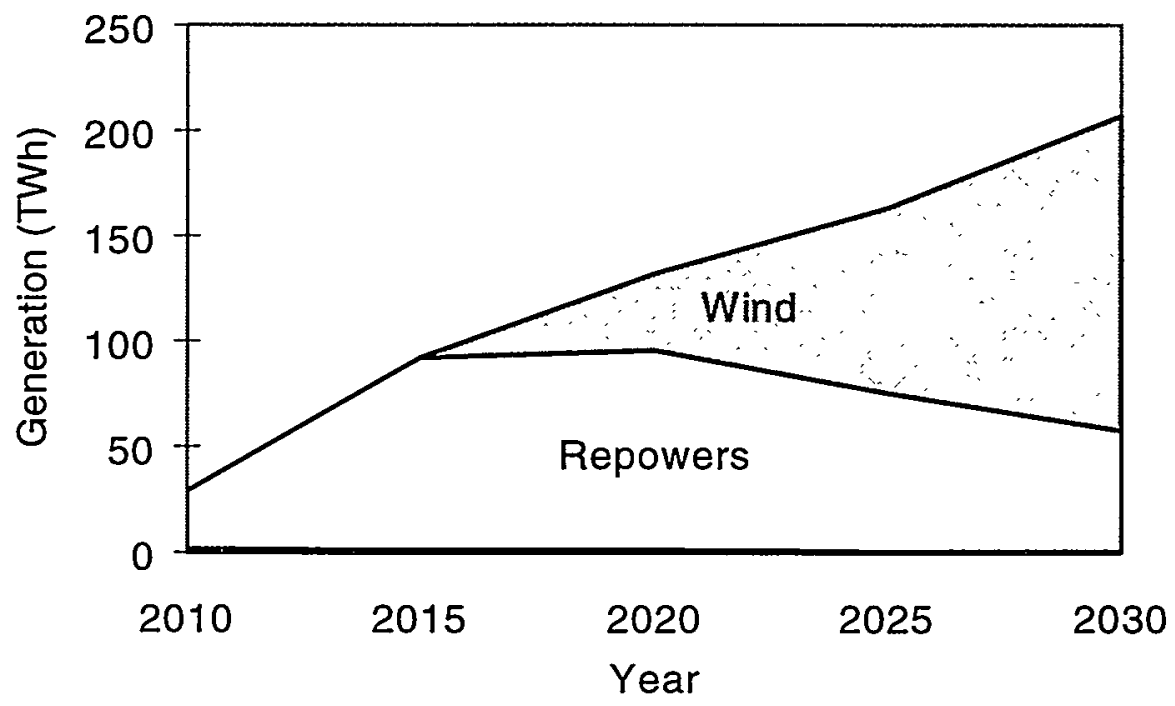




\section{Current Results with Actual Wind Resources}

With the detailed representation of the wind sites developed here incorporated into the Elfin model, generation expansion evolves as shown in Figure 25. Each stripe within the area marked "wind" represents one of the 36 sites. A. major share of the total resource is profitable in 2006. In later years, some of the less favorable sites become profitable and wind capacity expands. However, the limit of wind capacity as specified in the input data is never reached, showing that under the assumption of the simulation, an economic result has been found. By the year $2010,4.6 \mathrm{GW}$ of wind capacity is developed, and this figure increases to $7.4 \mathrm{GW}$ by the year 2030. Figure 26 presents the generation for this scenario in which wind generation from new wind resources reaches 62 TWh by the year 2030 .

Figure 25. Generation Expansion with Actual Resources: Best-Guess Scenario

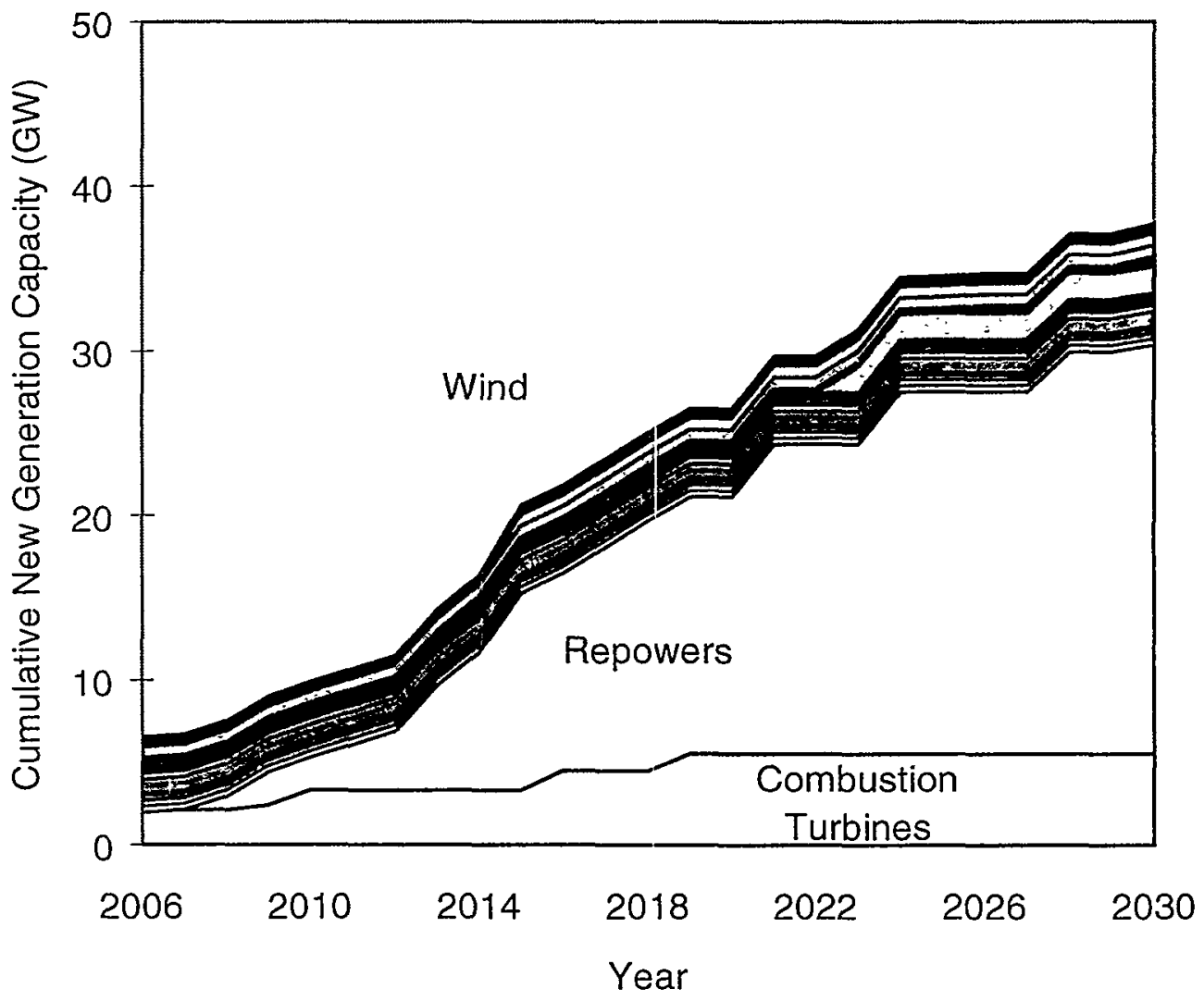


Figure 26. Generation from New Facilities with Actual Wind Resources: Best-Guess Case

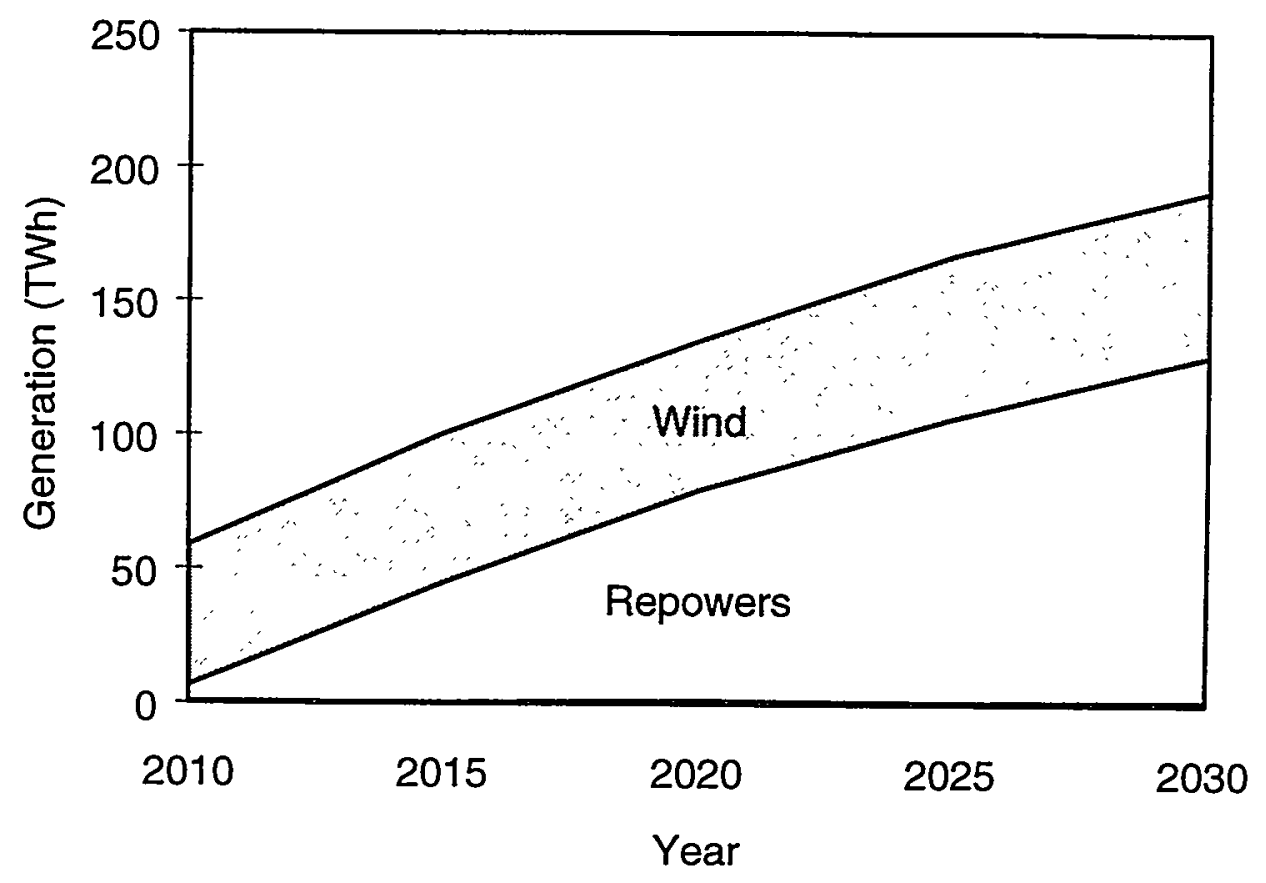

The sensitivity of these results to future natural gas prices is also studied. In the best guess scenario, gas prices increase by $1.5 \% / \mathrm{a}$, while under high and low gas price scenarios, natural gas prices increase by zero and three percent, respectively. The results for the low gas price scenario is presented in Figures 27 and 28. The results for the high gas price scenario is presented in Figures 29 and 30. It should be noted that there is not much difference between the best guess and the high gas price scenarios, while in the low gas price scenario, by the year 2030 , about 30 percent less wind capacity is developed compared to that in the best-guess scenario. That gap is filled with combined-cycle generators. 
Figure 27. Generation Expansion with Actual Wind Resources: Low Gas Price Scenario

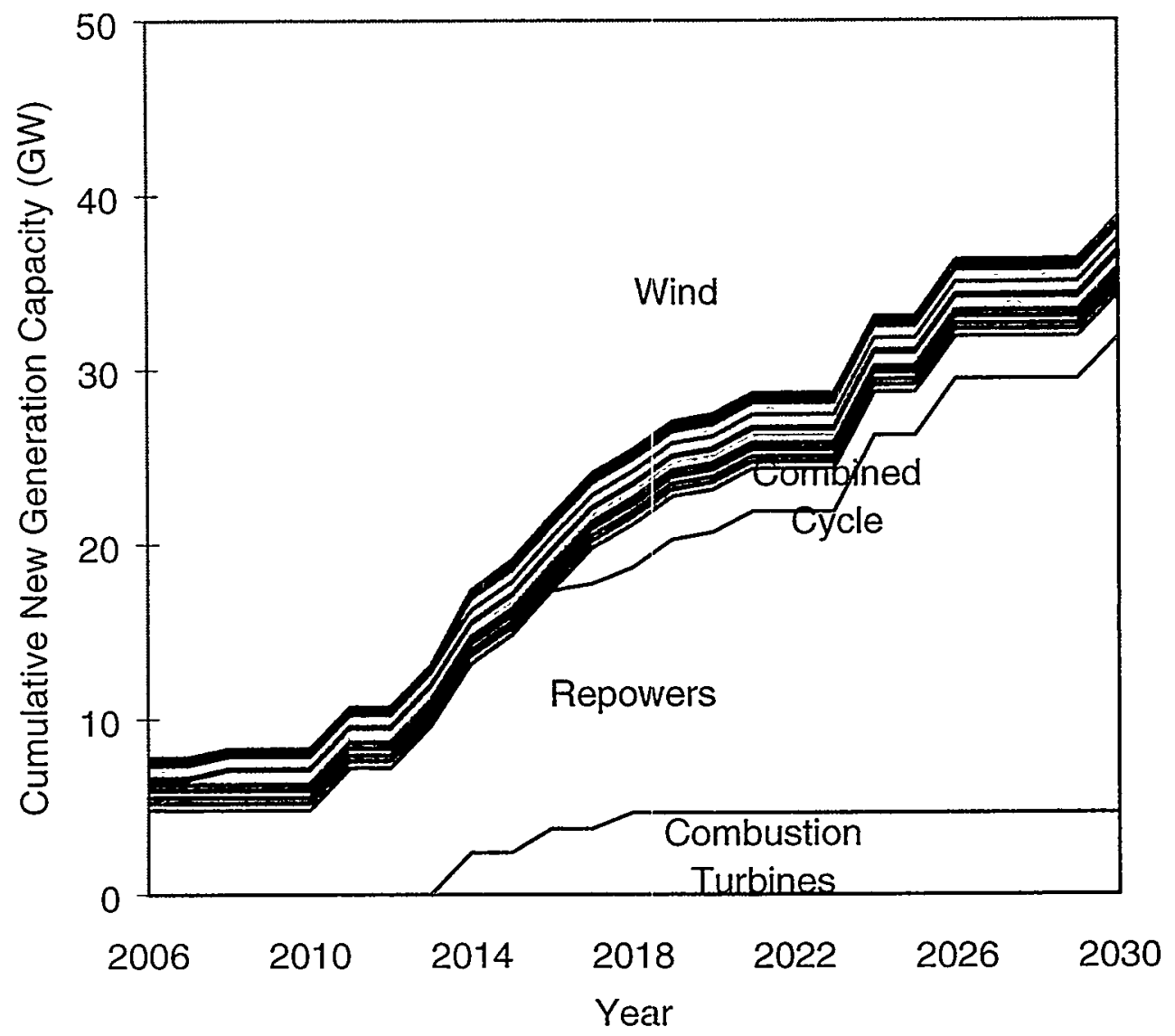


Figure 28. Generation from New Facilities with Actual Wind Resources: Low Gas Price Scenario

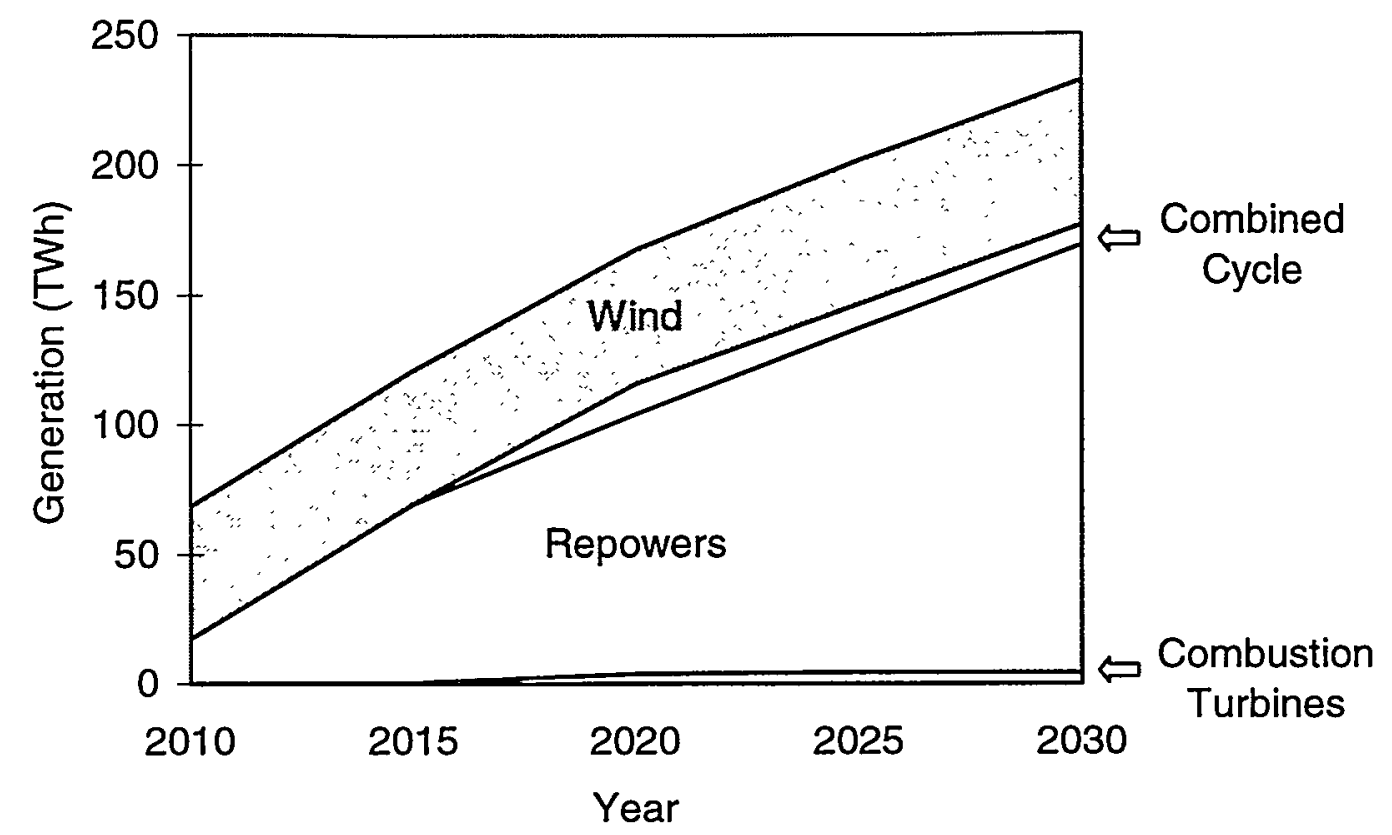


Figure 29. Generation Expansion with Actual Wind Resources: High Gas Price Scenario

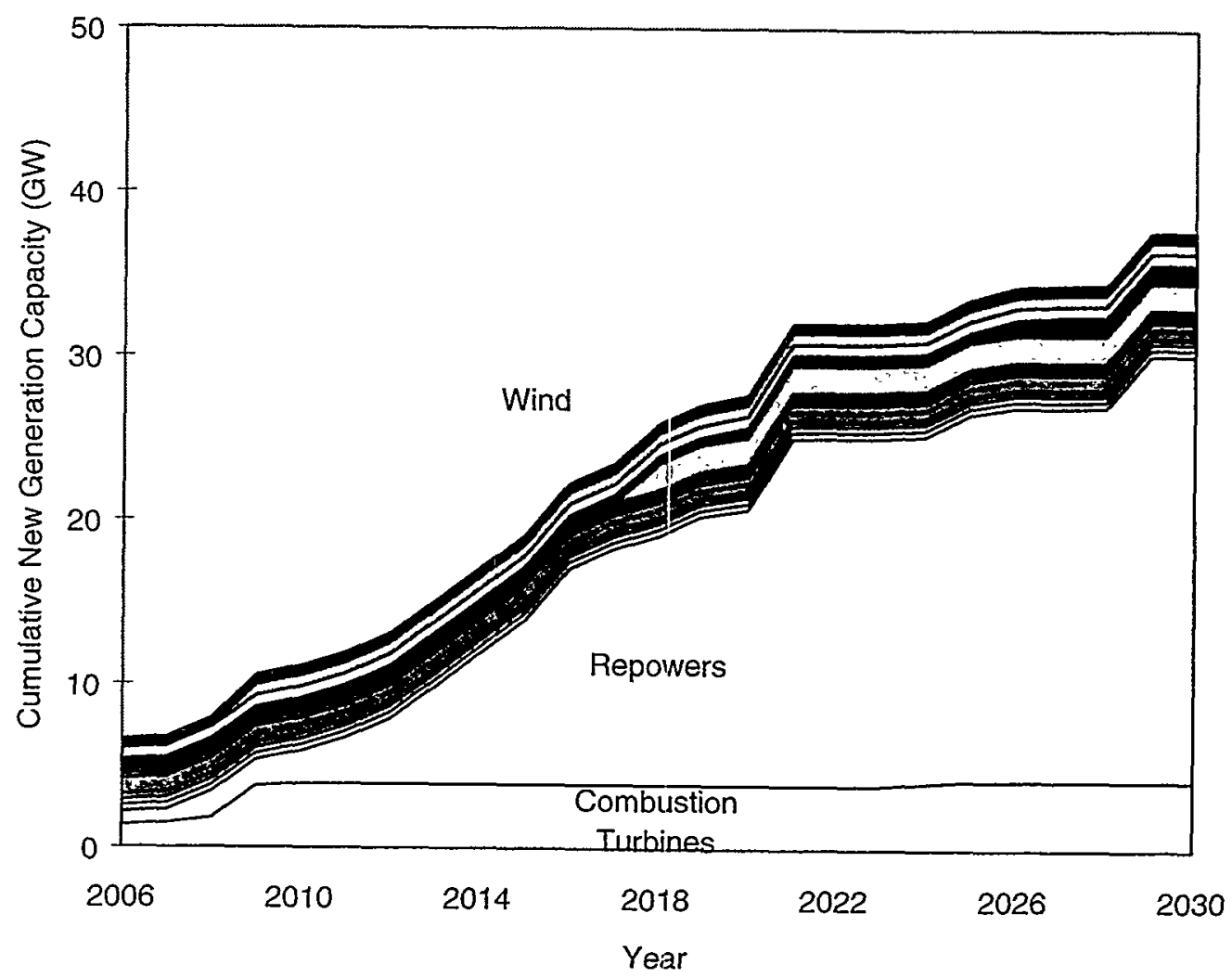


Figure 30. Generation from New Facilities with Actual Wind Resources: High Gas Price Scenario

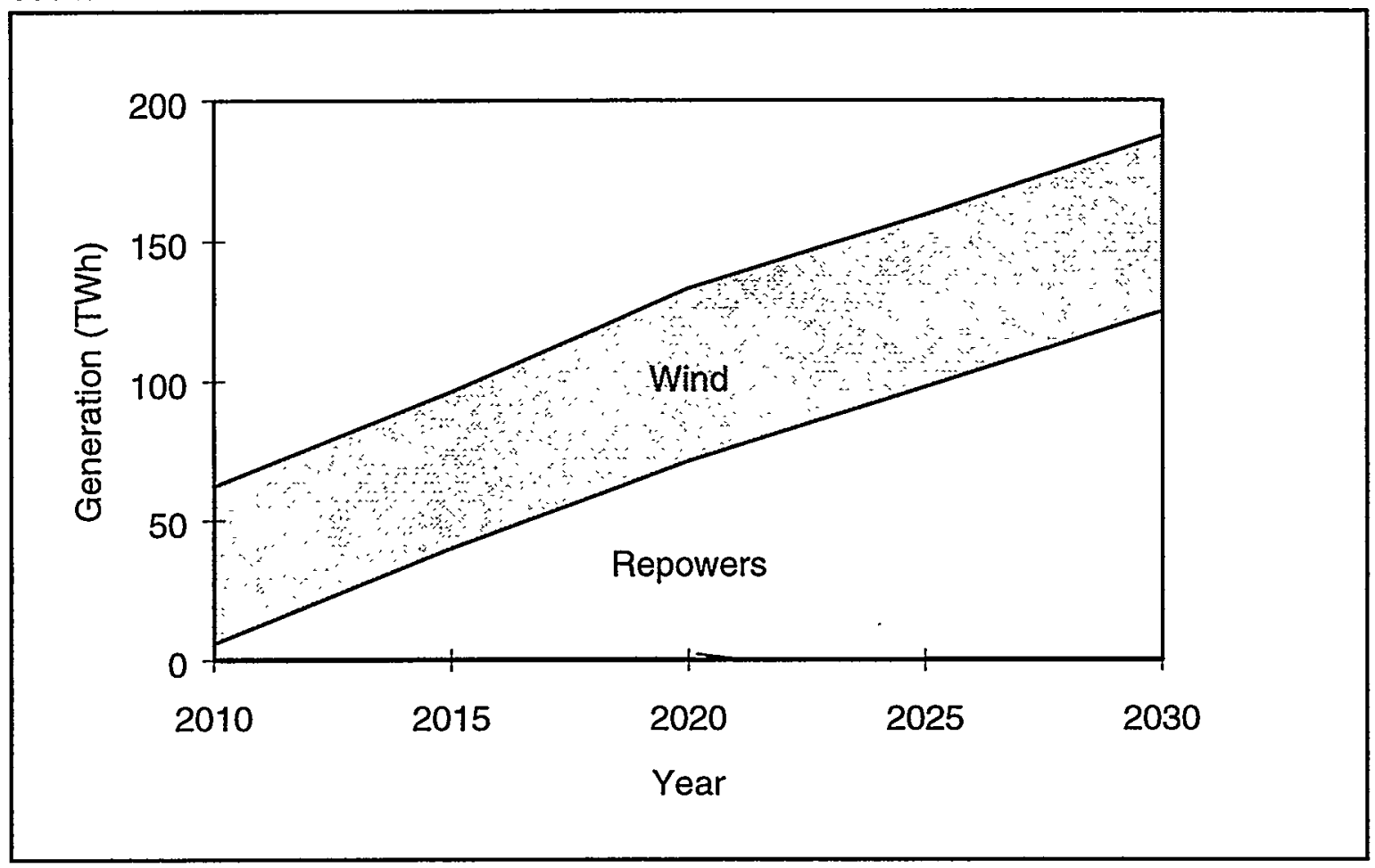

\section{Comparison of Elfin Model Results with Generic and Actual Resources}

Wind patterns are very different between sites, and one has to live with a single pattern in the former representation where only a single generic type is allowed. It is interesting to compare the results for high gas price scenario (Figures 23 and 29). In the generic representation associated with Figure 23, the generic wind pattern is possibly not as favorable, delaying the expansion of wind capacity until after 2018. In fact the wind data which is used for this generic case is from San Gorgonio. It is interesting to note that the development in that region happens also in 2018 for the scenario with detailed wind representation.

Another problem with the former generic representation is that there were no upper capacity limits. With the new, more detailed representation, each site has its capacity limit based on estimated actual physical limits.

Another notable feature of Figures 22, 27, and 29 is the role of repowers. This capacity expansion option, under the assumptions used in this simulation, is highly attractive as the results clearly show. It should be noted, however, that this option shares some key attributes with renewables; notably, development at any site requires unique design features and costs may diverge widely from generic assumptions. Since competition between repowers and renewables may be a feature of future investment patterns, the benefits of the Elfin approach are particularly appealing. 


\section{Comparison to Profitability Curve Approach}

The differences between the results of the traditional approach and Elfin simulations are: (1) more sites are profitable in the Elfin results, (2) some specific sites are developed earlier or later, and (3), one site that is profitable using the levelized-cost method is not chosen by the Elfin model. Table 7 compares the wind sites shown to be profitable in the previous section to the sites that are developed in the generation expansion plan generated by the Elfin model. By the year 2010, the model chooses not only all the sites that are shown to be profitable using the levelized cost method, but also Sites 10,12,21, and 25. By the year 2030, the model chooses most of the sites (all of the sites except Site 34) that are shown profitable using the levelized-cost method. In addition, the Elfin model chooses Sites 8, 11, 17, and 23. Although there are strong similarities, it is clear that simple levelized-cost analysis used in the traditional approach misses some of the sites that are built into the Elfin generation plan.

It can be noted that at one of these sites, Pacheco Pass (Site 35) about $16 \mathrm{MW}$ of wind generation capacity already exists. The results from both methods indicate that this site will not be profitable in the future California electricity market. One possible reason for this is that seasonal diurnal wind patterns are not available for this location and the annual diurnal pattern does not characterize the potential well enough.

Finally, please be reminded that although the rankings in Table 7 are similar, the Elfin plan $B$ is naturally superior in that development at sites can be economically expanded over any of the years of the study period. 
Table 7. Profitable Sites Generated by Levelized Cost Method versus the Elfin Model

\begin{tabular}{|c|c|c|c|}
\hline $\begin{array}{l}\text { Levelized Cost } \\
\text { Method }\end{array}$ & Elfin & $\begin{array}{l}\text { Levelizêd Cost } \\
\text { Method }\end{array}$ & Elfin \\
\hline 6 & 6 & 6 & 6 \\
\hline 26 & 26 & 24 & 24 \\
\hline 27 & 27 & 26 & 26 \\
\hline 30 & 30 & 27 & 27 \\
\hline 31 & 31 & 2 & 2 \\
\hline 2 & 2 & 30 & 30 \\
\hline 29 & 29 & 31 & 31 \\
\hline 28 & 28 & 4 & 4 \\
\hline 24 & 24 & 29 & 29 \\
\hline 4 & 4 & 28 & 28 \\
\hline 1 & 1 & 7 & 7 \\
\hline 7 & 7 & 1 & 1 \\
\hline 3 & 3 & 16 & 16 \\
\hline \multirow[t]{10}{*}{16} & 16 & 3 & 3 \\
\hline & 5 & 21 & 21 \\
\hline & 10 & 34 & 15 \\
\hline & 12 & 15 & 5 \\
\hline & 21 & 5 & 10 \\
\hline & 25 & 10 & 25 \\
\hline & & 25 & 8 \\
\hline & & & 11 \\
\hline & & & 17 \\
\hline & & & 23 \\
\hline
\end{tabular}




\section{Emissions}

Emission levels generated by Elfin simulations run using a generic wind resource and the more detailed wind-site data developed in this report are shown in Tables 8 and 10, respectively. It is clear that the results for the generic wind-resource case overestimated the emissions due to the fact that no wind resource is developed. Tables 9 and 11 show the change in the emissions relative to the best guess scenario in the generic and detailed wind cases respectively. Results for the generic wind resource case grossly overestimate the emission savings, especially after 2020 , because of the huge wind generation capacity expansion which starts in 2018 and makes further big jumps in 2021 and 2025. For the detailed wind case, the savings are not big since the differences between the best-guess and high gas price scenarios are not much different.

Table 8. Best-Guess Scenario with Generic Wind Resources: Emissions (kt)

\begin{tabular}{|lrrrrr|}
\hline & $\mathbf{2 0 1 0}$ & $\mathbf{2 0 1 5}$ & $\mathbf{2 0 2 0}$ & $\mathbf{2 0 2 5}$ & $\mathbf{2 0 3 0}$ \\
\hline oxides of nitrogen & 223 & 226 & 228 & 227 & 224 \\
sulfur oxides & 83 & 85 & 86 & 86 & 85 \\
particulate matter & 10 & 12 & 14 & 15 & 16 \\
$(<10 \mu \mathrm{m})$ & & & & & \\
reactive organic gases & 34 & 35 & 36 & 37 & 37 \\
carbon monoxide & 69 & 69 & 69 & 69 & 70 \\
$\begin{array}{l}\text { carbon portion of carbon } \\
\text { dioxide }\end{array}$ & 26345 & 30883 & 34651 & 37007 & 39684 \\
\hline
\end{tabular}

Table 9. Reduction in Emissions in High Gas Price Scenario with Generic Wind Resources

\begin{tabular}{|lccccc|}
\hline & $\mathbf{2 0 1 0}$ & $\mathbf{2 0 1 5}$ & $\mathbf{2 0 2 0}$ & $\mathbf{2 0 2 5}$ & $\mathbf{2 0 3 0}$ \\
\hline oxides of nitrogen & $-2 \%$ & $2 \%$ & $3 \%$ & $6 \%$ & $14 \%$ \\
sulfur oxides & $-3 \%$ & $10 \%$ & $12 \%$ & $16 \%$ & $32 \%$ \\
particulate matter & $2 \%$ & $0 \%$ & $12 \%$ & $26 \%$ & $41 \%$ \\
$(<10 \mu \mathrm{m})$ & & & & & \\
reactive organic gases & $0 \%$ & $-1 \%$ & $2 \%$ & $6 \%$ & $13 \%$ \\
carbon monoxide & $-1 \%$ & $0 \%$ & $2 \%$ & $4 \%$ & $11 \%$ \\
carbon portion of carbon & $-1 \%$ & $0 \%$ & $13 \%$ & $28 \%$ & $44 \%$ \\
dioxide & & & & & \\
\hline
\end{tabular}


Table 10. Best-Guess Scenario with Actual Wind Resources: Emissions (kt)

\begin{tabular}{|lrrrrr|}
\hline & $\mathbf{2 0 1 0}$ & $\mathbf{2 0 1 5}$ & $\mathbf{2 0 2 0}$ & $\mathbf{2 0 2 5}$ & $\mathbf{2 0 3 0}$ \\
\hline oxides of nitrogen & 202 & 212 & 216 & 211 & 214 \\
sulfur oxides & 67 & 71 & 73 & 67 & 71 \\
$\begin{array}{l}\text { particulate matter } \\
(<10 \mu \mathrm{m})\end{array}$ & 8 & 10 & 11 & 12 & 13 \\
reactive organic gases & 32 & 34 & 35 & 35 & 36 \\
$\begin{array}{l}\text { carbon monoxide } \\
\text { carbon portion of carbon } \\
\text { dioxide }\end{array}$ & 66 & 66 & 67 & 67 & 67 \\
\hline
\end{tabular}

Table 11. Reduction in Emissions in High Gas Price Scenario with Actual Wind Resources

\begin{tabular}{|lccccc|}
\hline & $\mathbf{2 0 1 0}$ & $\mathbf{2 0} 1 \mathbf{5}$ & $\mathbf{2 0 2 0}$ & $\mathbf{2 0 2 5}$ & $\mathbf{2 0 3 0}$ \\
\hline oxides of nitrogen & $0 \%$ & $-1 \%$ & $-1 \%$ & $-4 \%$ & $-2 \%$ \\
sulfur oxides & $3 \%$ & $-2 \%$ & $-3 \%$ & $-13 \%$ & $-\mathbf{7 \%}$ \\
$\begin{array}{l}\text { particulate matter } \\
(<10 \mu \mathrm{m})\end{array}$ & $1 \%$ & $1 \%$ & $-3 \%$ & $1 \%$ & $1 \%$ \\
$\begin{array}{l}\text { reactive organic gases } \\
\text { carbon monoxide }\end{array}$ & $0 \%$ & $0 \%$ & $0 \%$ & $0 \%$ & $0 \%$ \\
$\begin{array}{l}\text { carbon portion of carbon } \\
\text { dioxide }\end{array}$ & $0 \%$ & $-1 \%$ & $0 \%$ & $-1 \%$ & $0 \%$ \\
\hline
\end{tabular}




\section{Future Work}

Future work will concentrate on three areas: (1) improving the estimation of cost of development and operation at each of the sites, (2) including areas which are either not covered by the CEC studies or which have low average wind speeds but possibly favorable wind profiles, and (3) including out-of-state resources that may compete in the California market.

In this demonstration, costs depended only on the distance to transmission lines and distance to roads and the transmission data used are only approximate. In the future, a more accurate map of transmission lines will be available from the CEC. Since the process for mapping and calculating distances with the FEMA transmission data layer has been set up, improving the accuracy of results by substituting the CEC data for the FEMA data layer is straightforward.

Cost is also a function of the terrain, distance to population centers, land values, and many other factors, many of which are amenable to a GIS approach. More simply, however, one desirable GIS improvement is the inclusion of population density maps for the wind sites which would serve as a proxy for land value. Population data can be obtained from the U.S. Census Bureau, matched with the appropriate polygon data layer (county or tract) and mapped. GIS can also be used to improve cost calculations by incorporating the slopes of the terrain at different sites. This slope affects the cost of construction of both the wind farm and the transmission lines.

The graphic quality of the relief maps can be improved by creating colored three-dimensional grids of the surface. Creating these graphics requires some additional processing that was outside the scope of this project.

The choice of wind sites relies on CEC studies done more than ten years ago. The wind intensity map (Figure 3) indicates favorable areas in the Sierras which are not covered by the CEC studies. The potential for that area could be estimated using newer GIS methods or a tool such as WindMap. ${ }^{14}$ Also, the 36 sites selected for this study probably cover most of the wind potential in the studied area but still there may be sites with low annual average wind speeds but very favorable wind patterns or locations which might be profitable. It will be worthwhile to look at all of the sites included in the CEC studies for a second time from this perspective. Finally, there might be remote sites which are far from transmission lines but close to small demand centers.

Parsons and Wan (1995) indicate that the wind potential of areas within $16 \mathrm{~km}$ of the transmission lines is about $350 \mathrm{GW}$ in the U.S. The areas covered in this report are only about two percent of this potential. Out-of-state resources sending electricity to California may prove to be profitable and future studies need to investigate such potential. 
Other future enhancements will include: (1) introduction of trends in the size of the turbines, (2) modeling power reduction in multiple-row wind sites, (3) examination of the effects of using data from different years for the different sites. 


\section{Conclusion}

In this demonstration analysis, a characterization of the wind potential of California has been developed using archival studies conducted by the CEC and by using GIS. The resource is represented as an Elfin input data set that was subsequently run using the Berkeley Lab's data set for the future competitive electricity market. Preliminary results indicate that about 7.5 GW of the 10-GW potential capacity in the 36 specific sites can be profitably developed by the year 2030 and 62 TWh of electricity can be produced per annum by the year 2030 . Furthermore, most of the development happens during the earlier years of the forecast.

Another conclusion is that simple levelized-cost analyses do not sufficiently capture the implications of time-varying prices in a competitive market. The differences between the results of the traditional approach and Elfin simulations are: (1) more sites are profitable in the Elfin results, (2) some specific sites are developed earlier or later, and (3), one site which is shown to be profitable using levelized-cost analysis is not chosen by the Elfin model for development. 


\section{References}

Berry, E.X, R.K. Hauser, and W.G. Lane 1981. "A Wind Energy Assessment of the Southern California Desert." Atmospheric Research \& Technology, Inc. CEC Consultant Report Number P500-81-025.

Brower, C.B., M.W. Tennis, E.W. Denzler, and M.M. Kaplan 1993. "Powering the Midwest: Renewable Electricity for the Economy and the Environment." Union of Concerned Scientists, Cambridge, Massachusetts.

Davis, E. and R. Nierenberg 1980. "Wind Energy Prospecting in Alameda and Solano Counties." Volumes 1-2. Pacific Gas and Electric Company, San Francisco, California. CEC Consultant Report Number P500-80-054.

Environmental Defense Fund (EDF) 1997. "Elfin: Electric Utility Production Simulation and Integrated Planning System." Oakland, California.

Eldridge, R.E. 1975. "Wind Machines." Prepared for the Notional Science Foundation by The Mithre Corporation.

Elliott, D.L., C.G. Holladay, W.R. Barchet, H.P. Foote, W.F. Sandusky 1986. "Wind Energy Resource Atlas of the U.S.” NREL National Wind Technology Center, Golden, CO. DOE/CH 10093-4. October.

Elliott, D.L, and M.N. Schwartz 1997. "Wind Energy Potential in the United States." National Renewable Energy Laboratory. Golden, CO.

Environmental Systems Research Institute (ESRI) 1993. "Arc Info v. 7.0.4, Arcview U.S. Road Data Set."

Federal Energy Management Agency (FEMA) 1988. Transmission Line Database developed by FEMA with assistance from Argonne National Laboratory.

Gipe, P. 1995. "Wind Energy Comes of Age." John Wiley \& Sons, Inc.

Marnay, C., Suzie Kito, and Osman Sezgen 1997a. "Entry into a Competitive Electricity Market: The Fate of Renewable Generators in the California Pool Beyond 2005." Proceedings of the United States Association for Energy Economics and the International Association of Energy Economics, International Energy Markets, Competition and Policy, San Francisco, California, 7-10 Sep.

Marnay, C., C. Richey, S. Mahler, and R. Markel 1997b. "Estimating the Environmental and Economic Effects of Residential PV Adoption Using GIS and NEMS." Proceedings of the 1997 Annual Conference of the American Solar Energy Society, Washington, D.C., 25-30 April.

Marnay, Chris, Dan Kirshner, Suzie Kito, Osman Sezgen, Steve Pickle, Katja Schumacher, and Ryan Wiser 1998. "Restructuring and Renewable Energy Developments in California: Using Elfin to Simulate the Future California Power Market." Berkeley, California. June.

NREL 1996. Wind Energy Information Guide. U.S. Department of Energy, Washington, DC.

Parsons, B. and Y.H. Wan 1995. "US wind reserves accessible to transmission lines." IEEE Power Engineering Review. Vol. 15(9).

Plaks, A., W. Wiesner, G.E. Miller, and R.L. Nielsen 1980. "Wind Turbine System for High Wind Regions of California." Boeing Engineering and Construction Company, Seattle, Washington. CEC Consultant 
Report Number P500-80-005.

Richmond, M.C. and R. Anderson 1984. "Wind Prospécting in San Diego County California: Summary Report." Meteorological Research, Inc., Canyon Country, California. CEC Consultant Report Number P500-84-005.

Ruff, R.E., M.K. Bland, R.M. Endlich, R.L. Kiang, and L. Jones 1983. "Wind Energy Assessment for Northwestern California." Volume 1. SRI International, Menlo Park, California. CEC Consultant Report Number P500-83-021.

Simon, R.L. 1980. "Location of Sites for Wind Power Development in Northeastern California." Global Weather Consultants, Inc., San Jose California. CEC Consultant Report Number P500-80-053.

U.S. Department of the Interior (DOI) 1983. "Central California-Nevada Wind Energy Study." U.S. Department of the Interior, Bureau of Reclamation, Mid-Pacific Region. Sacramento, California.

U.S. Geographical Survey (USGS) 1990. "One-Degree Digital Elevation Models." Originated from the Defense Mapping Agency. Reston, VA.

Waco, D., M. Wurst, M.D. Batham, S. Michael, and R.W. Kukulka 1983. "Wind Resource Assessment of California." California Energy Commission, Sacramento, California. CEC Staff Report P500-83-019.

Zambrano, T.G., S.N. Walker, and R.W. Baker 1980. "Wind Energy Assessment of the Palm Springs-Whitewater Region." Volume 1. Aero Vironment Inc., Pasadena, California. CEC Consultant Report Number P500-80-016. Co-funded by Southern California Edison.

Zambrano, T.G. and G.J. Arcemont. 1981. "Wind Energy Assessment Studies for Southern California." Volumes 1-4. Aero Vironment Inc., Pasadena, California. CEC Consultant Report Number P500-81-031. 


\section{Appendix A: Data on Wind Sites}

Table A-1 presents a summary of the characteristics of the sites used in this study (land characteristics, land use, generation capacity, revenues, costs, and wind characteristics). Generation capacity is estimated based on data on the size of the area. Revenues are estimated using the hourly (or every three hours) wind data and the marginal busbar costs for the pool.

Figures A-1 through A-5 depict the diurnal wind patterns for a few sites. For some sites, these patterns are differentiated for only two seasons (Sites 1, 15, 16, 24, 26, 27, 28, 29, 30, 31). For the coastal mountain sites (Sites 32,33,34, 35, and 36) the diurnal patterns are not differentiated seasonally. 
Table A-1. Wind Site Characteristics

\begin{tabular}{|c|c|c|c|c|c|c|}
\hline Site & $\begin{array}{c}1 \\
\text { Bear River } \\
\text { Ridge }\end{array}$ & $\begin{array}{c}2 \\
\begin{array}{c}\text { Solano Hills } \\
\text { (good) }\end{array} \\
\end{array}$ & $\begin{array}{c}3 \\
\text { Solano Hills } \\
\text { (marginal) }\end{array}$ & \begin{tabular}{l}
\multicolumn{4}{c}{4} \\
Altamont Pass \\
(good)
\end{tabular} & $\begin{array}{c}5 \\
\begin{array}{c}\text { Altamont Pass } \\
\text { (marginal) }\end{array}\end{array}$ & $\begin{array}{c}6 \\
\begin{array}{c}\text { San Gorgonio } \\
\text { (best) }\end{array} \\
\end{array}$ \\
\hline Land Characteristics & $\begin{array}{c}97 \mathrm{~km}(60 \mathrm{mi}) \\
\text { of ridge line }\end{array}$ & $\begin{array}{c}31 \mathrm{~km}^{2} \\
7700 \text { acres }\end{array}$ & $\begin{array}{c}26 \mathrm{~km}^{2} \\
6400 \text { acres }\end{array}$ & $\begin{array}{c}52 \mathrm{~km}^{2} \\
13,000 \text { acres }\end{array}$ & $\begin{array}{c}68 \mathrm{~km}^{2} \\
17,000 \text { acres }\end{array}$ & $\begin{array}{c}80 \mathrm{~km}^{2} \\
20,000 \text { acres }\end{array}$ \\
\hline Land Use & & Cattle Grazing & Cattle Grazing & Cattle Grazing & Cattle Grazing & Rural Residential \\
\hline \multicolumn{7}{|l|}{ Estimated Generation Capacity } \\
\hline Potential Capacity (MW) $\{C E C\}$ & 425 & 500 (all Solano) & 500 (all Solano) & 1000 (all Altamont) & 1000 (all Altamont) & 3300 (all San Gorgonio) \\
\hline Potential Capacity (MW) \{LBNL $\}$ & 399 & 397 & 330 & 670 & 876 & 309 \\
\hline Potential Electricity Output (TWh/a) $\{C E C\}$ & & 1.2 (all Solano) & 1.2 (all Solano) & 2.4 (all Altamont) & 2.4 (all Altamont) & 7 (all San Gorgonio) \\
\hline \multicolumn{7}{|l|}{ Estimated Revenues } \\
\hline Revenue per Wind Generator (\$/a) & 68093 & 106148 & 59285 & 71938 & 40179 & 178635 \\
\hline Revenue for the Site (M\$/a) & 54.339 & 84.186 & 39.081 & 96.326 & 70.353 & 110.396 \\
\hline \multicolumn{7}{|l|}{ Estimated Costs } \\
\hline Distance to Transmission Lines $(\mathrm{km})$ & 35.3 & 0.7 & 0.4 & 0.7 & 1.3 & 1.3 \\
\hline Cost to Connect to the Grid (\$) & 4889000 & 391000 & 352000 & 391000 & 469000 & 469000 \\
\hline Substation (\$) & 3000000 & 3000000 & 3000000 & 3000000 & 3000000 & 3000000 \\
\hline Cost of Lines Within the Farm (\$) & 4800000 & 4584195 & 3810240 & 7739550 & 10120950 & 3572100 \\
\hline Distance to Roads (km) & 4.4 & 2.9 & 2.6 & 2.3 & 0.3 & 3.7 \\
\hline Cost to Connect to the Existing Roads (\$) & 96800 & 63800 & 57200 & 50600 & 6600 & $81400^{\circ}$ \\
\hline Land Costs $(\$)^{15}$ & 13200 & 8700 & 7800 & 6900 & 900 & 11100 \\
\hline Cost of Turbines (million $\$$ ) & 399 & 396.55 & 329.6 & 669.5 & 875.5 & 309 \\
\hline Total Capital Outlay (M\$) & 411.799 & 404.598 & 336.827 & 680.688 & 889.097 & 316.134 \\
\hline Capital Outlay $/ \mathrm{kW}$ & 1032 & 1020 & 1022 & 1017 & 1016 & 1023 \\
\hline Maintenance (M\$/a) (est LF 0.3) & 12.583 & 12.506 & 10.394 & 21.113 & 27.610 & 9.745 \\
\hline Rent for Land (M\$/a) & 0.3192 & 0.31724 & 0.26368 & 0.5356 & 0.7004 & 0.618 \\
\hline \multicolumn{7}{|l|}{ Wind Characteristics } \\
\hline Average Annual Wind Speed (m/s) & 7.3 & 7.5 & 6.2 & 7.5 & 6.2 & 9.9 \\
\hline
\end{tabular}

$15 \quad 1 \mathrm{~km}$ requires $0.006 \mathrm{~km}^{2}(1.5$ acre $) ; 0.004 \mathrm{~km}^{2}$ ( 1 acre) costs $\$ 2000$ 
Table A-1. Wind Site Characteristics (continued)

\begin{tabular}{|c|c|c|c|c|c|c|}
\hline Site & $\begin{array}{c}7 \\
\text { San Gorgonio } \\
\text { (good) } \\
\text { Whitewater }\end{array}$ & $\begin{array}{c}8 \\
\text { San Gorgonio } \\
\text { (marginal) } \\
\text { Cabazon }\end{array}$ & $\begin{array}{c}9 \\
\text { Tehachapi Pass } \\
\text { (good) } \\
\text { Cameron and } \\
\text { Oak Ridges } \\
\end{array}$ & $\begin{array}{c}10 \\
\text { Tehachapi Pass } \\
\text { (good) } \\
\text { Pajuela Peak }\end{array}$ & $\begin{array}{c}11 \\
\text { Tehachapi Pass } \\
\text { (marginal) } \\
\text { Downslope (CPC- } \\
1 \text { ) }\end{array}$ & $\begin{array}{c}12 \\
\text { Tehachapi } \\
\text { Mountains } \\
\text { La Liebre Ridge } \\
\text { (half good) }\end{array}$ \\
\hline Land Characteristics & $\begin{array}{l}80 \mathrm{~km}^{2} \text { (best+good) } \\
20000 \text { acres } \\
\text { (best+good) } \\
14000 \text { acres (est.) }\end{array}$ & $\begin{array}{c}128 \mathrm{~km}^{2} \\
32000 \text { acres }\end{array}$ & $\begin{array}{c}23 \mathrm{~km} \text { of ridge } \\
14 \text { miles of ridge }\end{array}$ & $\begin{array}{l}5 \mathrm{~km} \text { ridge } \\
3 \text { miles ridge }\end{array}$ & $\begin{array}{c}52 \mathrm{~km}^{2} \\
20 \text { sq.miles }\end{array}$ & $\begin{array}{l}23 \mathrm{~km} \text { ridgeline } \\
14 \text { miles ridgeline }\end{array}$ \\
\hline Land Use & Rural Residential & Rural Residential & & & & \\
\hline Estimated Generation Capacity & & & & & & \\
\hline Potential Capacity (MW) $\{C E C\}$ & $\begin{array}{c}3300 \text { (all San } \\
\text { Gorgonio) }\end{array}$ & $\begin{array}{c}3300 \text { (All San } \\
\text { Gorgonio) }\end{array}$ & 575 (all T. Pass) & & 575 (all T. Pass) & 280 \\
\hline Potential Capacity (MW) \{LBNL $\}$ & 721 & 1648 & 93 & 20 & 674 & 93 \\
\hline $\begin{array}{l}\text { Potential Electricity Output (TWh/a) } \\
\{\text { CEC }\} \\
\text { Estimated Revenues }\end{array}$ & 7 (all San Gorgonio) & 7 (all San Gorgonio) & & & & \\
\hline $\begin{array}{l}\text { Revenue per Wind Generator (\$/a) } \\
\text { Revenue for the Site (M\$/a) } \\
\text { Estimated Costs }\end{array}$ & $\begin{array}{l}61257 \\
88.332\end{array}$ & $\begin{array}{l}28166 \\
92.836\end{array}$ & $\begin{array}{l}54168 \\
10.086\end{array}$ & $\begin{array}{l}54168 \\
2.161\end{array}$ & $\begin{array}{l}24898 \\
33.568\end{array}$ & $\begin{array}{l}32678 \\
6.085\end{array}$ \\
\hline $\begin{array}{l}\text { Distance to Transmission Lines }(\mathrm{km}) \\
\text { Cost to Connect to the Grid (\$) }\end{array}$ & $\begin{array}{c}3.3 \\
729000\end{array}$ & $\begin{array}{c}0.7 \\
391000\end{array}$ & $\begin{array}{c}22.2 \\
3186000\end{array}$ & $\begin{array}{c}40.4 \\
5552000\end{array}$ & $\begin{array}{c}13.6 \\
2068000\end{array}$ & $\begin{array}{c}3.2 \\
716000\end{array}$ \\
\hline Substation (\$) & 3000000 & 3000000 & 3000000 & 3000000 & 3000000 & 3000000 \\
\hline Cost of Lines Within the Farm (\$) & 8334900 & 19051200 & 1120000 & 240000 & 7770000 & 1120000 \\
\hline Distance to Roads (km) & 0.7 & 1.3 & 1.6 & 7.1 & 12.7 & 9.6 \\
\hline Cost to Connect to Existing Roads (\$) & 15400 & 28600 & 35200 & 156200 & 279400 & 211200 \\
\hline Cost of Turbines (million \$) & 721 & 1648 & 93.1 & 19.95 & 674.1 & 93.1 \\
\hline Total Capital Outlay (M\$) & 733.081 & 1670.475 & 100.446 & 28.920 & 687.256 & 98.176 \\
\hline Capital Outlay/kW & 1017 & 1014 & 1079 & 1450 & 1020 & 1055 \\
\hline Maintenance (M\$/a) (est LF 0.3) & 22.737 & 51.971 & 2.936 & 0.629 & 21.258 & 2.936 \\
\hline $\begin{array}{l}\text { Rent for Land (M\$/a) } \\
\text { Wind Characteristics }\end{array}$ & 1.442 & 3.296 & 0.07448 & 0.01596 & 0.53928 & 0.07448 \\
\hline Average Annual Wind Speed (m/s) & 7.4 & 5.9 & 6.9 & 6.9 & 5.5 & 6.1 \\
\hline
\end{tabular}


Table A-1. Wind Site Characteristics (continued)

\begin{tabular}{|c|c|c|c|c|c|c|}
\hline Site & $\begin{array}{c}13 \\
\text { Barstow } \\
\text { (good) }\end{array}$ & $\begin{array}{c}14 \\
\text { Barstow } \\
\text { (marginal) } \\
\text { four locations } \\
\end{array}$ & $\begin{array}{c}15 \\
\begin{array}{c}\text { Mountain Pass } \\
\text { (good) }\end{array}\end{array}$ & 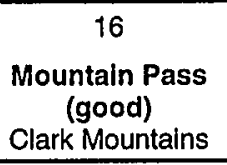 & $\begin{array}{c}17 \\
\text { Gorman } \\
\text { Sandberg } \\
\end{array}$ & $\begin{array}{c}18 \\
\text { Sierra Pelona }\end{array}$ \\
\hline Land Characteristics & $13 \mathrm{~km}^{2}$ & $923 \mathrm{~km}^{2}$ & 1 mile ridge & $13 \mathrm{~km}^{2}$ & $\begin{array}{c}13 \mathrm{~km}^{2} \\
5 \mathrm{sq} \text { miles }\end{array}$ & $\begin{array}{l}29 \mathrm{~km} \text { ridge } \\
18 \text { miles ridge }\end{array}$ \\
\hline \multicolumn{7}{|l|}{ Land Use } \\
\hline \multicolumn{7}{|l|}{ Estimated Generation Capacity } \\
\hline Potential Capacity (MW) \{CEC\} & 75 (all Barstow) & 75 (all Barstow) & 25 (all pass) & 25 (all pass) & & \\
\hline Potential Capacity (MW) \{LBNL\} & 34 & 303 & 7 & 34 & 169 & 120 \\
\hline \multicolumn{7}{|l|}{ Potential Electricity Output (TWh/a) \{CEC\} } \\
\hline \multicolumn{7}{|l|}{ Estimated Revenues } \\
\hline Revenue per Wind Generator (\$/a) & 0 & 0 & 59196 & 59196 & 26433 & 17374 \\
\hline Revenue for the Site $(M \$ / a)$ & - & - & 0.787 & 3.990 & 8.909 & 4.159 \\
\hline \multicolumn{7}{|l|}{ Estimated Costs } \\
\hline Distance to Transmission Lines $(\mathrm{km})$ & 0.8 & 0.3 & 1.3 & 0.4 & 1.1 & 6.2 \\
\hline Cost to Connect to the Grid (\$) & 404000 & 339000 & 469000 & 352000 & 443000 & 1106000 \\
\hline Substation (\$) & 3000000 & 3000000 & 3000000 & 3000000 & 3000000 & 3000000 \\
\hline Cost of Lines Within the Farm (\$) & 388500 & 3496500 & 80000 & 388500 & 1942500 & 1440000 \\
\hline Distance to Roads (km) & 0.4 & 2.1 & 3 & 3.9 & 0.3 & 4.9 \\
\hline Cost to Connect to the Existing Roads (\$) & 8800 & 46200 & 66000 & 85800 & 6600 & 107800 \\
\hline Land Costs (\$) & 1200 & 6300 & 9000 & 11700 & 900 & 14700 \\
\hline Cost of Turbines (million $\$$ ) & 33.705 & 303.345 & 6.65 & 33.705 & 168.525 & 119.7 \\
\hline Total Capital Outlay (M\$) & 37.508 & 310.233 & 10.274 & 37.543 & 173.918 & 125.369 \\
\hline Capital Outlay $/ \mathrm{kW}$ & 1113 & 1023 & 1545 & 1114 & 1032 & 1047 \\
\hline Maintenance (M\$/a) (est LF 0.3) & 1.063 & 9.566 & 0.210 & 1.063 & 5.315 & 3.775 \\
\hline Rent for Land (M\$/a) & 0.026964 & 0.242676 & 0.00532 & 0.026964 & 0.13482 & 0.09576 \\
\hline \multicolumn{7}{|l|}{ Wind Characteristlcs } \\
\hline Average Annual Wind Speed $(\mathrm{m} / \mathrm{s})$ & & 2.7 & 7.6 & 7.6 & 5.8 & 5.0 \\
\hline
\end{tabular}


Table A-1. Wind Site Characteristics (continued)

\begin{tabular}{|c|c|c|c|c|c|c|}
\hline Site & $\begin{array}{c}19 \\
\text { Soledad Canyon }\end{array}$ & $\begin{array}{c}20 \\
\text { Portal Ridge } \\
\text { Assumption } \\
\end{array}$ & $\begin{array}{c}21 \\
\text { Fairmont Reservoir }\end{array}$ & $\begin{array}{c}22 \\
\text { Santa Catalina } \\
\text { Ben Weston Ridge } \\
\end{array}$ & $\begin{array}{c}23 \\
\text { Cajon Pass }\end{array}$ & $\begin{array}{c}24 \\
\text { Cajon Mountain }\end{array}$ \\
\hline Land Characteristics & $\begin{array}{c}13 \mathrm{~km}^{2} \\
5 \text { sq.miles }\end{array}$ & $\begin{array}{c}32 \mathrm{~km} \text { ridge } \\
20 \text { miles ridge }\end{array}$ & $\begin{array}{l}52 \mathrm{~km}^{2} \text { (estimate) } \\
20 \mathrm{sq} . \text { miles } \\
\text { (estimate) }\end{array}$ & $\begin{array}{c}8 \mathrm{~km}^{2} \\
3 \mathrm{sq} \cdot \mathrm{miles}\end{array}$ & $\begin{array}{c}52 \mathrm{~km}^{2} \\
20 \mathrm{sq} . \text { miles }\end{array}$ & $\begin{array}{c}8 \mathrm{~km} \text { of ridge } \\
5 \text { miles of ridge }\end{array}$ \\
\hline $\begin{array}{l}\text { Land Use } \\
\text { Estimated Generation Capacity } \\
\text { Potential Capacity (MW) }\{\mathrm{CEC}\}\end{array}$ & & Ranchland & & & Private Parcels & \\
\hline $\begin{array}{l}\text { Potential Capacity (MW) \{LBNL }\} \\
\text { Potential Electricity Output (TWh/a) \{CEC }\} \\
\text { Estimated Revenues }\end{array}$ & 169 & 133 & 674 & 101 & 674 & 33 \\
\hline Revenue per Wind Generator (\$/a) & 17374 & 17374 & 44700 & 0 & 23782 & 85213 \\
\hline $\begin{array}{l}\text { Revenue for the Site }(M \$ / a) \\
\text { Estimated Costs }\end{array}$ & 5.856 & 4.621 & 60.265 & - & 32.062 & 5.667 \\
\hline Distance to Transmission Lines $(\mathrm{km})$ & 0.6 & 1.8 & 1.1 & & 4.7 & 1.2 \\
\hline Cost to Connect to the Grid (\$) & 378000 & 534000 & 443000 & & 911000 & 456000 \\
\hline Substation (\$) & 3000000 & 3000000 & 3000000 & 3000000 & 3000000 & 3000000 \\
\hline Cost of Lines within the Farm $(\$)$ & 1942500 & 1600000 & 7770000 & & 7770000 & 400000 \\
\hline Distance to Roads (km) & 9.2 & 0.4 & 5.3 & & 3.2 & 0.4 \\
\hline Cost to Connect to the Existing Roads (\$) & 202400 & 8800 & 116600 & & 70400 & 8800 \\
\hline Land Costs (\$) & 27600 & 1200 & 15900 & 0 & 9600 & 1200 \\
\hline Cost of Turbines (million \$) & 168.525 & 133 & 674.1 & 101.115 & 674.1 & 33.25 \\
\hline Total Capital Outlay (M\$) & 174.076 & 138.144 & 685.446 & & 685.861 & 37.116 \\
\hline Capital Outlay/kW & 1033 & 1039 & 1017 & \#VALUE! & 1017 & 1116 \\
\hline Maintenance (M\$/a) (est LF 0.3) & 5.315 & 4.194 & 21.258 & 3.189 & 21.258 & 1.049 \\
\hline $\begin{array}{l}\text { Rent for Land }(\mathrm{M} \$ / \mathrm{a}) \\
\text { Wind Characteristics }\end{array}$ & 0.13482 & 0.1064 & 0.53928 & 0.080892 & 0.53928 & 0.0266 \\
\hline Average Annual Wind Speed (m/s) & 5.0 & 5.0 & & & 5.3 & \\
\hline
\end{tabular}


Table A-1. Wind Site Characteristics (continued)

\begin{tabular}{|c|c|c|c|c|c|c|}
\hline \multirow[b]{3}{*}{ Site } & \multirow{3}{*}{$\begin{array}{c}25 \\
\text { Strawberry Peak }\end{array}$} & \multirow{3}{*}{$\begin{array}{c}26 \\
\text { Mt. Laguna }\end{array}$} & \multirow{3}{*}{$\begin{array}{c}27 \\
\text { Jullan } \\
\text { Vulcan Mtn }\end{array}$} & 28 & 29 & \multirow{3}{*}{$\begin{array}{c}30 \\
\text { Table Mountain }\end{array}$} \\
\hline & & & & \multicolumn{2}{|c|}{ In-Ko_Pah } & \\
\hline & & & & Boulder Park & Sugarloaf Mtn. & \\
\hline \multirow[t]{2}{*}{ Land Characteristics } & $16 \mathrm{~km}$ ridge (est.) & $24 \mathrm{~km}$ of ridge & $16 \mathrm{~km}$ ridge & \multicolumn{2}{|c|}{$6 \mathrm{~km}$ ridge (estimate) } & $\begin{array}{l}8 \mathrm{~km} \text { ridge } \\
\text { (estimate) }\end{array}$ \\
\hline & 10 miles ridge (est.) & 15 miles of ridge & 10 miles ridge & \multicolumn{2}{|c|}{4 miles ridge (estimate) } & $\begin{array}{l}5 \text { miles ridge } \\
\text { (estimate) }\end{array}$ \\
\hline \multicolumn{7}{|l|}{ Land Use } \\
\hline \multicolumn{7}{|l|}{ Estimated Generation Capacity } \\
\hline Potential Capacity (MW) \{CEC\} & & 220 & & 55 & & 65 \\
\hline Potential Capacity (MW) \{LBNL & 67 & 100 & 67 & 12 & 12 & 32 \\
\hline \multicolumn{7}{|l|}{ Potential Electricity Output (TWh/a) \{CEC\} } \\
\hline \multicolumn{7}{|l|}{ Estimated Revenues } \\
\hline Revenue per Wind Generator ( $\$ / a)$ & 39683 & 183795 & 183795 & 183795 & 183795 & 183795 \\
\hline Revenue for the Site (M\$/a) & 5.278 & 36.667 & 24.445 & 4.583 & 4.583 & 11.667 \\
\hline \multicolumn{7}{|l|}{ Estimated Costs } \\
\hline Distance to Transmission Lines (km) & 0.2 & 29.6 & 26.3 & 49.6 & 40.3 & 49.6 \\
\hline Cost to Connect to the Grid (\$) & 326000 & 4148000 & 3719000 & 6748000 & 5539000 & 6748000 \\
\hline Substation (\$) & 3000000 & 3000000 & 3000000 & 3000000 & 3000000 & 3000000 \\
\hline Cost of Lines within the Farm (\$) & 800000 & 1200000 & 800000 & 160000 & 160000 & 400000 \\
\hline Distance to Roads $(\mathrm{km})$ & 1.2 & 0.4 & 2.2 & 1.6 & 0.9 & 3.7 \\
\hline Cost to Connect to the Existing Roads (\$) & 26400 & 8800 & 48400 & 35200 & 19800 & 81,400 \\
\hline Land Costs (\$) & 3600 & 1200 & 6600 & 4800 & 2700 & 11100 \\
\hline Cost of Turbines (million \$) & 66.5 & 99.75 & 66.5 & 12.47 & 12.47 & 31.74 \\
\hline Total Capital Outlay (M\$) & 70.656 & 108.108 & 74.074 & 22.417 & 21.190 & 41.979 \\
\hline Capital Outlay/kW & 1062 & 1084 & 1114 & 1798 & 1699 & 1323 \\
\hline Maintenance (M\$/a) (est LF 0.3) & 2.097 & 3.146 & 2.097 & 0.393 & 0.393 & 1.001 \\
\hline Rent for Land (M\$/a) & 0.0532 & 0.0798 & 0.0532 & 0.0100 & 0.0100 & 0.0254 \\
\hline \multicolumn{7}{|l|}{ Wind Characteristics } \\
\hline Average Annual Wind Speed $(\mathrm{m} / \mathrm{s})$ & 6.6 & 7.9 & 8.6 & 9.0 & 6.4 & 8.8 \\
\hline
\end{tabular}


Table A-1. Wind Site Characteristics (continued)

\begin{tabular}{|c|c|c|c|c|c|c|}
\hline Site & $\begin{array}{c}31 \\
\text { Jacumba } \\
\text { Mountains }\end{array}$ & $\begin{array}{c}32 \\
\text { Walker Ridge }\end{array}$ & $\begin{array}{c}33 \\
\text { Berryessa Peak }\end{array}$ & $\begin{array}{c}34 \\
\text { Potrero Hills }\end{array}$ & $\begin{array}{c}35 \\
\text { Pacheco Pass }\end{array}$ & $\begin{array}{c}36 \\
\text { Cottonwood Pass }\end{array}$ \\
\hline \multirow[t]{2}{*}{ Land Characteristics } & $5 \mathrm{~km}$ of ridge & $8 \mathrm{~km}$ of ridge & $16 \mathrm{~km}$ of ridge & $31 \mathrm{~km}^{2}$ & $13 \mathrm{~km}^{2}$ (estimate) & $13 \mathrm{~km}^{2}$ (estimate) \\
\hline & 3 miles of ridge & 5 miles of ridge & 10 miles of ridge & 12 sq. miles & 5 sq. miles (estimate) & 5 sq. miles (estimate) \\
\hline \multicolumn{7}{|l|}{ Land Use } \\
\hline \multicolumn{7}{|l|}{ Estimated Generation Capacity } \\
\hline Potential Capacity (MW) \{CEC\} & 45 & & & & & \\
\hline Potential Capacity (MW) \{LBNL\} & 20 & 33 & 67 & 404 & 169 & 169 \\
\hline \multicolumn{7}{|l|}{ Potential Electricity Output (TWh/a) \{CEC\} } \\
\hline \multicolumn{7}{|l|}{ Estimated Revenues } \\
\hline Revenue per Wind Generator (\$/a) & 183795 & 32360 & 16756 & 48458 & 17550 & 25945 \\
\hline Revenue for the Site (M\$/a) & 7.333 & 2.152 & 2.228 & 39.198 & 5.915 & 8.745 \\
\hline \multicolumn{7}{|l|}{ Estimated Costs } \\
\hline Distance to Transmission Lines (km) & 49.6 & 2.8 & 5.7 & 4.4 & 7.4 & 11 \\
\hline Cost to Connect to the Grid $(\$)$ & 6748000 & 664000 & 1041000 & 872000 & 1262000 & 1730000 \\
\hline Substation (\$) & 3000000 & 3000000 & 3000000 & 3000000 & 3000000 & 3000000 \\
\hline Cost of Lines within the Farm (\$) & 240000 & 400000 & 800000 & 4662000 & 1942500 & 1942500 \\
\hline Distance to Roads (km) & 5.1 & 4.3 & 5.5 & 2.4 & 0.3 & 0.1 \\
\hline Cost to Connect to the Existing Roads (\$) & 112200 & 94600 & 121000 & 52800 & 6600 & 2200 \\
\hline Land Costs (\$) & 15300 & 12900 & 16500 & 7200 & 900 & 300 \\
\hline Cost of Turbines (million \$) & 19.95 & 33.25 & 66.5 & 404.46 & 168.525 & 168.525 \\
\hline Total Capital Outlay (M\$) & 30.066 & 37.422 & 71.479 & 413.054 & 174.737 & 175.200 \\
\hline Capital Outlay/kW & 1507 & 1125 & 1075 & 1021 & 1037 & 1040 \\
\hline Maintenance (M\$/a) (est LF 0.3) & 0.629 & 1.049 & 2.097 & 12.755 & 5.315 & 5.315 \\
\hline Rent for Land (M\$/a) & 0.01596 & 0.0266 & 0.0532 & 0.323568 & 0.13482 & 0.13482 \\
\hline \multicolumn{7}{|l|}{ Wind Characteristics } \\
\hline Average Annual Wind Speed $(\mathrm{m} / \mathrm{s})$ & 8.8 & 6.7 & 5.2 & 7.2 & 5.2 & 5.5 \\
\hline
\end{tabular}


Figure A-1. Solano Hills (Site 2) Wind Pattern

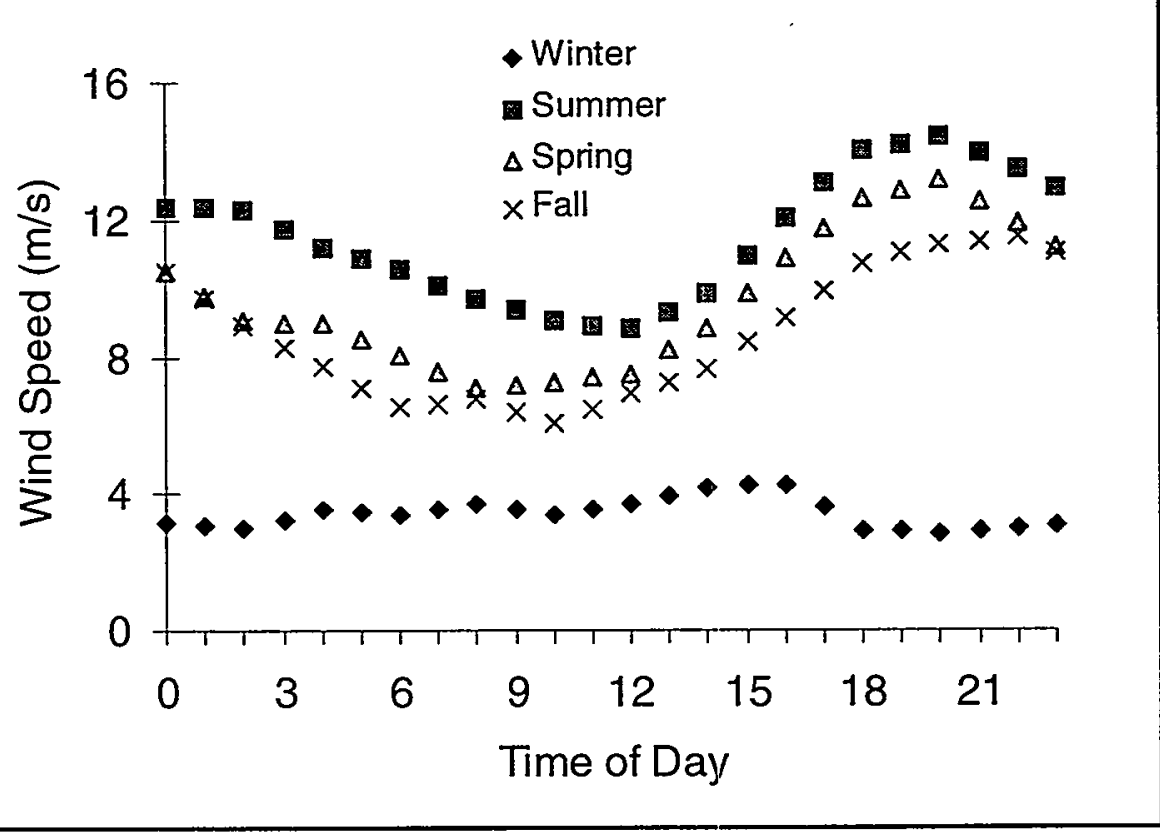

Figure A-2. San Gorgonio (Site 6) Wind Pattern

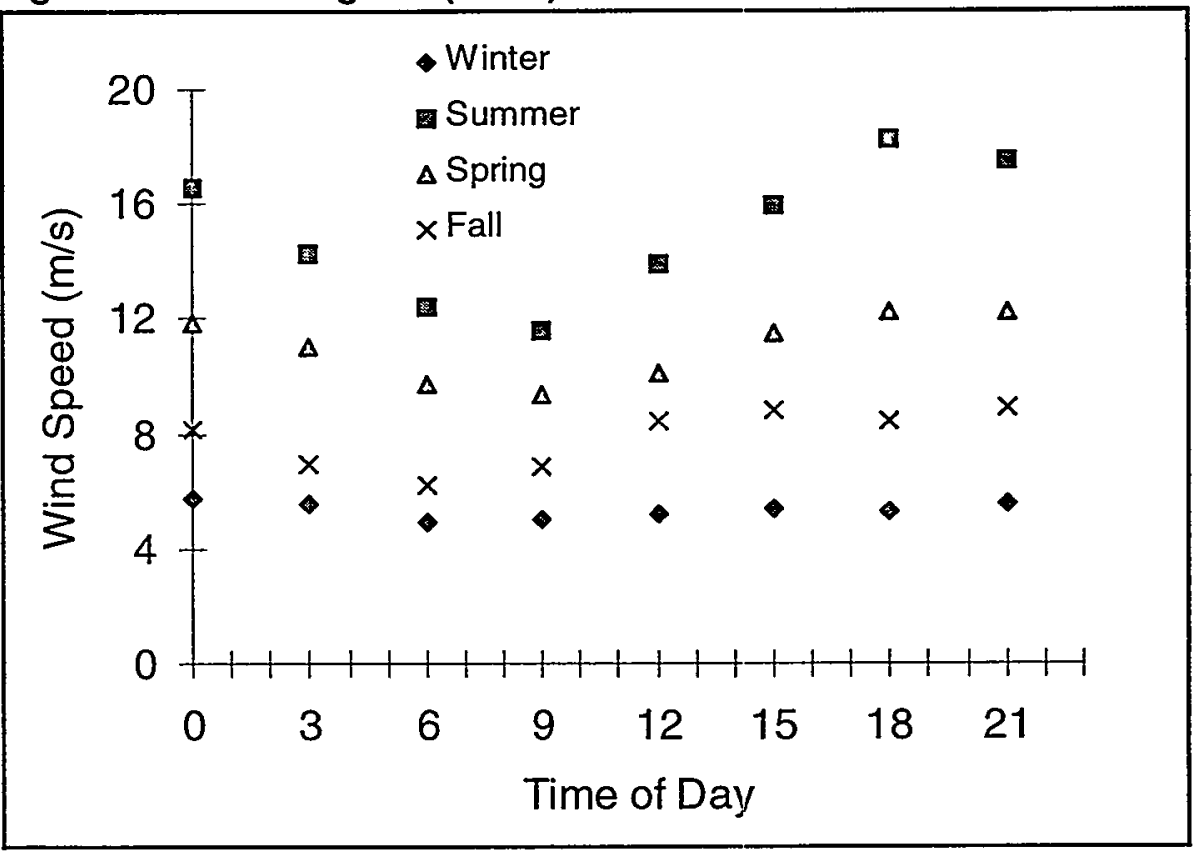


Figure A-3. In-Ko-Pah (Site 28) Wind Pattern

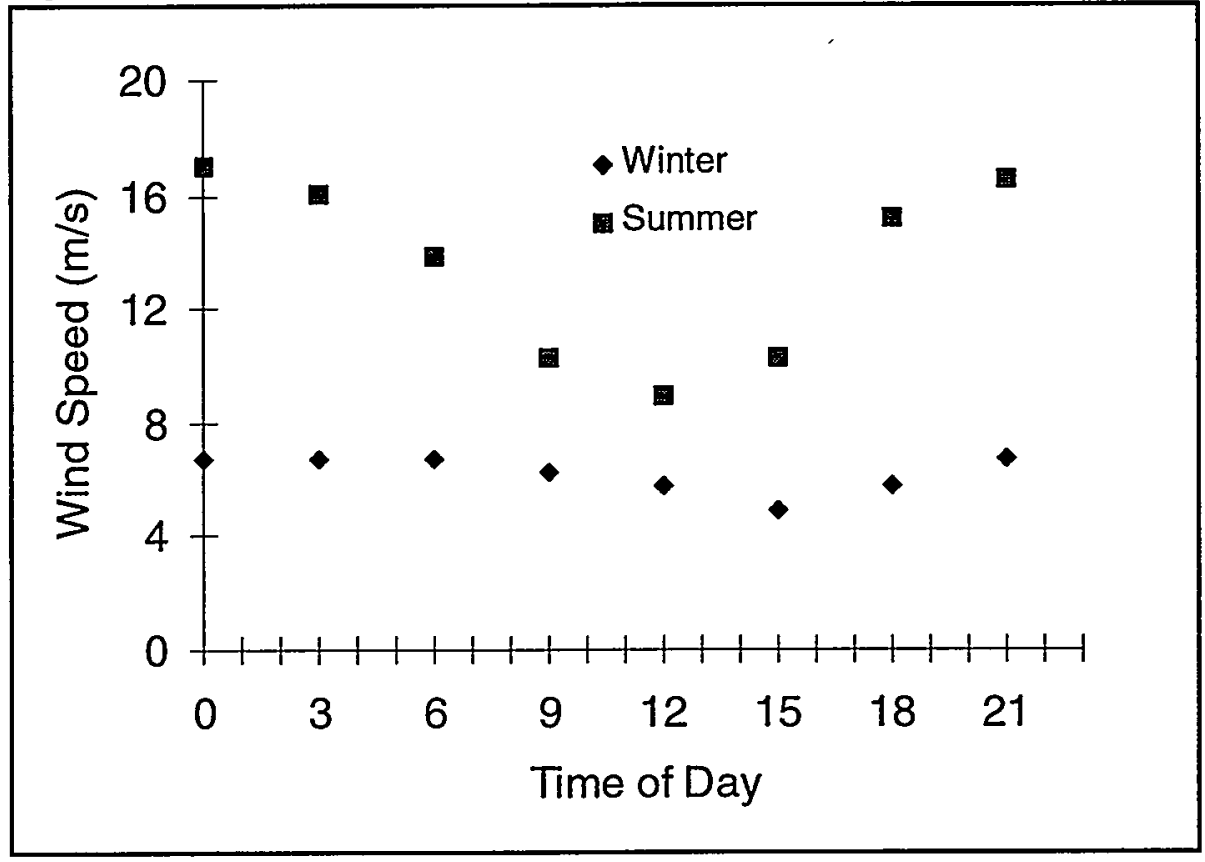

Figure A-4. Altamont Pass (Site 4) Wind Pattern

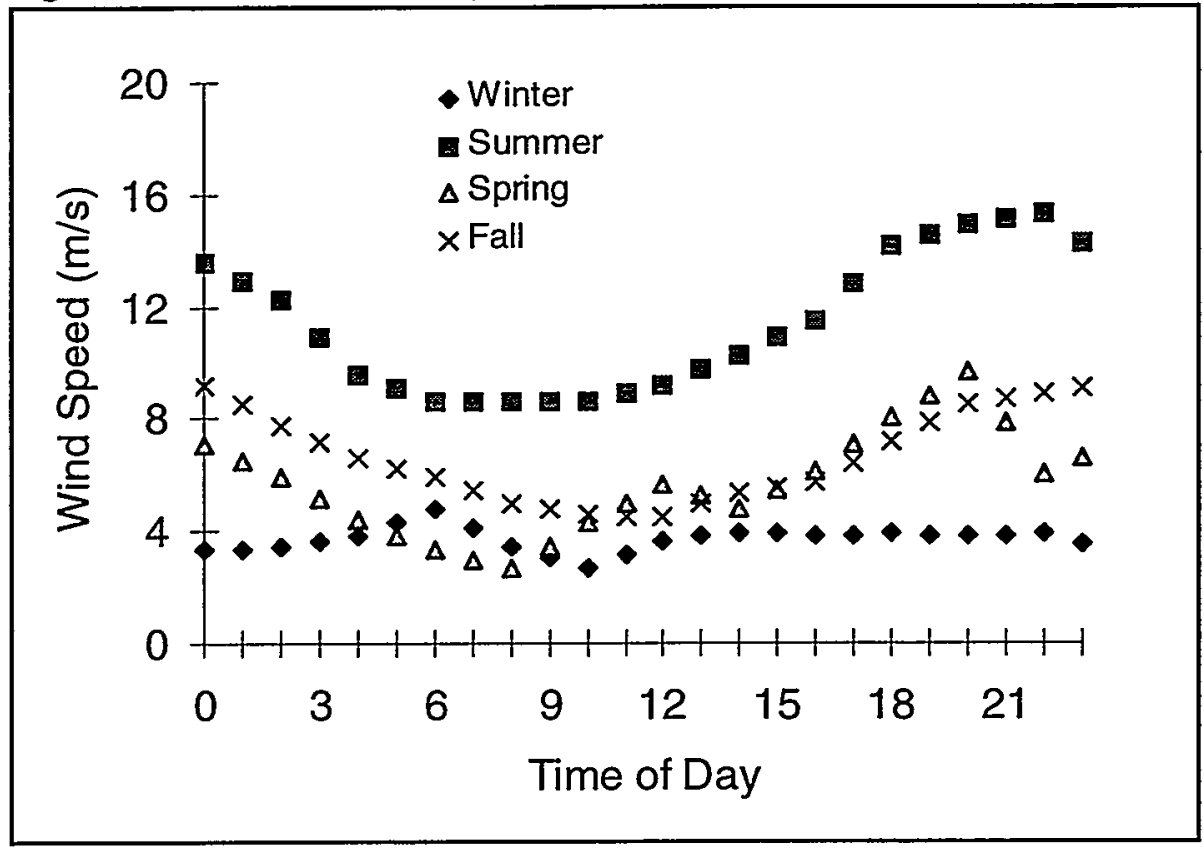


Figure A-5. Tehachapi Pass (Site 9) Wind Pattern

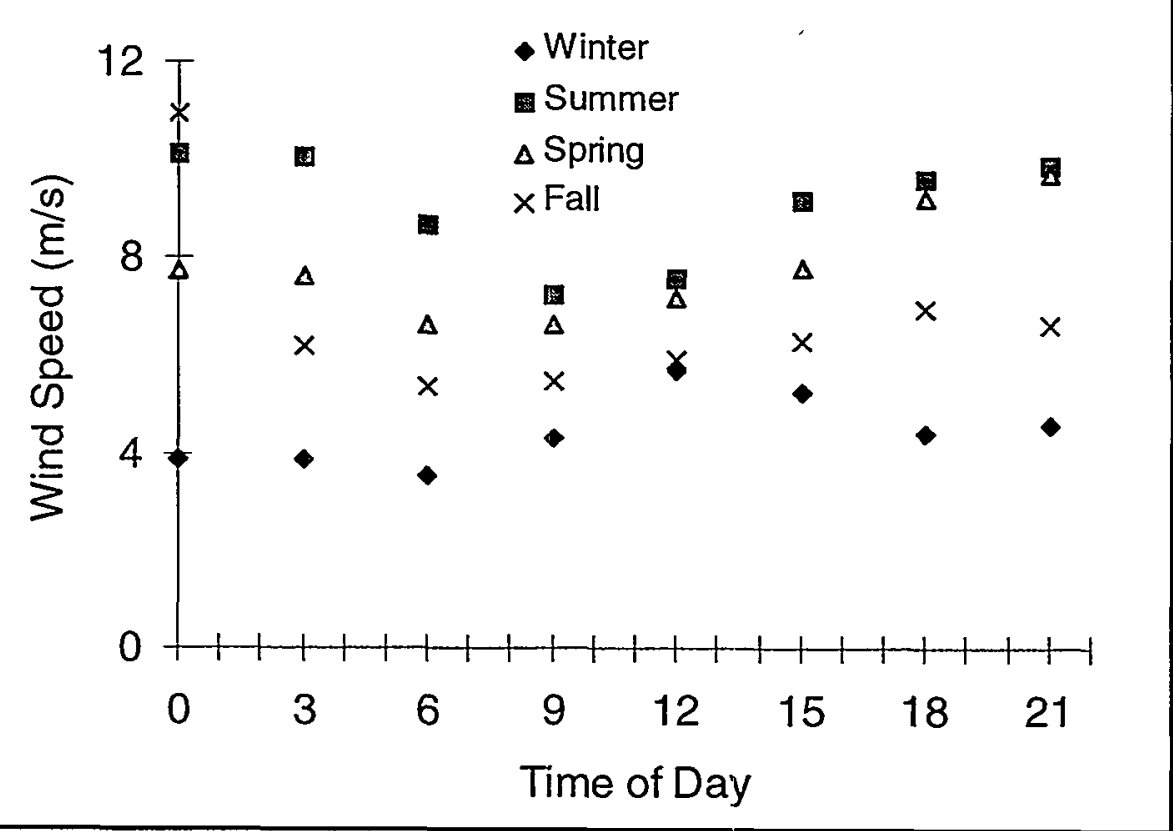




\section{Appendix B: Sample Wind Input to the Elfin Model}

36 actual sites from the CEC studies.

Site 1

wn01cp 1

$\mathrm{nc}=50 \quad \# \mathrm{dc}=50$

$\begin{array}{lllllll}22 & 33.30 & 33.30 & 78.94 & 78.94 & 78.94 & 78.94\end{array}$

$\begin{array}{llllll}78.94 & 78.94 & 33.30 & 33.30 & 33.30 & 33.30\end{array}$

wn01mu 1

17 y1991 0

wn01fc 1

20

wn01mr 1

20.025

wn01fr 1

20.000

wn01vi 1 changed to $1995 \$$; assuming .0075 real escalation

$\begin{array}{lll}\$ / \mathrm{kwh} & 2 & 0.00\end{array}$

wn01vx 1

$\mathrm{vx}=\mathrm{srch}$

wn01kp 1 base case capital costs

$\mathrm{pl}=30$ es $=0.0$ y $\$=1995 \mathrm{lf}=0.09$

$\$ / \mathrm{kw} 11032$ Y1995 0.0 Y1996-0.0115 Y2031 0.0

wn01mx 1 this scenario is to exclude the resource in the default case

17 y1995 0

wn $01 \mathrm{mx} 2$ this scenario to preclude this option

17 y1995 0

wn01mx 51

17 y1995 0

y1996 8

wn01fx 1 changed to $1995 \$$

$\mathrm{y} \$=1995$ es=genf

$\$ / \mathrm{kw} 226$

wn01sh 1 Subperiod shaping

29 y199101 mon

$\begin{array}{llllll}12 \mathrm{am} & 0.579 & 3 \mathrm{am} & 0.523 & 6 \mathrm{am} & 0.377\end{array}$

$\begin{array}{llllll}9 \mathrm{am} & 0.523 & 12 \mathrm{pm} & 0.579 & 3 \mathrm{pm} & 0.770\end{array}$

$\begin{array}{llll}6 \mathrm{pm} & 1.000 \quad 9 \mathrm{pm} 0.842\end{array}$

y199103 mon $\quad$ 12am 0.579 3am 0.388. 6am 0.388

$\begin{array}{llllll}9 \mathrm{am} & 0.388 & 12 \mathrm{pm} & 0.388 & 3 \mathrm{pm} & 0.719\end{array}$ 


\begin{tabular}{|c|c|c|c|c|}
\hline \multirow{3}{*}{ y199106 mon } & $6 \mathrm{pm}$ & 1.000 & $9 \mathrm{pm} \quad 0.824$ & \multirow{3}{*}{$\begin{array}{cc}6 \mathrm{am} & 0.388 \\
3 \mathrm{pm} & 0719\end{array}$} \\
\hline & $12 \mathrm{am}$ & 0.579 & 3am 0.388 & \\
\hline & 9am & 0.388 & $12 \mathrm{pm} 0.388$ & \\
\hline \multirow{4}{*}{ y199109 mon } & $6 \mathrm{pm}$ & 1.000 & $9 \mathrm{pm} \quad 0.824$ & \\
\hline & $12 \mathrm{am}$ & 0.579 & 3am 0.523 & 6am 0.377 \\
\hline & $9 \mathrm{am}$ & 0.523 & $12 \mathrm{pm} \quad 0.579$ & 3pm 0.770 \\
\hline & $6 \mathrm{pm}$ & 1.000 & $9 \mathrm{pm} 0.842$ & \\
\hline \multirow[t]{3}{*}{ y199112 mon } & $12 \mathrm{am}$ & 0.579 & 3am 0.523 & 6am 0.377 \\
\hline & 9am & 0.523 & $12 \mathrm{pm} 0.579$ & $3 \mathrm{pm} \quad 0.770$ \\
\hline & 1.000 & $9 \mathrm{pm}$ & 0.842 & \\
\hline
\end{tabular}

